\title{
The entheogenic origins of Mormonism: A working hypothesis*
}

\author{
ROBERT BECKSTEAD ${ }^{1}$, BRYCE BLANKENAGEL ${ }^{2}$, CODY NOCONI $^{3}$ and MICHAEL WINKELMAN ${ }^{4 * *}$ \\ ${ }^{1}$ Retired, Department of Emergency Medicine, Pocatello, ID, USA \\ ${ }^{2}$ Naked Mormonism Podcast, Seattle, WA, USA \\ ${ }^{3}$ Independent Researcher, Portland, OR, USA \\ ${ }^{4}$ Retired, School of Human Evolution and Social Change, Arizona State University, Tempe, AZ, USA
}

(Received: March 19, 2019; accepted: June 8, 2019)

\begin{abstract}
Historical documents relating to early Mormonism suggest that Joseph Smith (1805-1844) employed entheogeninfused sacraments to fulfill his promise that every Mormon convert would experience visions of God and spiritual ecstasies. Early Mormon scriptures and Smith's teachings contain descriptions consistent with using entheogenic material. Compiled descriptions of Joseph Smith's earliest visions and early Mormon convert visions reveal the internal symptomology and outward bodily manifestations consistent with using an anticholinergic entheogen. Due to embarrassing symptomology associated with these manifestations, Smith sought for psychoactives with fewer associated outward manifestations. The visionary period of early Mormonism fueled by entheogens played a significant role in the spectacular rise of this American-born religion. The death of Joseph Smith marked the end of visionary Mormonism and the failure or refusal of his successor to utilize entheogens as a part of religious worship. The implications of an entheogenic origin of Mormonism may contribute to the broader discussion of the major world religions with evidence of entheogen use at their foundation and illustrate the value of entheogens in religious experience.
\end{abstract}

Keywords: Joseph Smith, Mormonism, entheogen, psychedelic, spirituality

\section{INTRODUCTION}

The number and quality of spiritual experiences reported by participants in early Mormonism (Welch \& Carlson, 2005) far exceeded the daily background frequency reported in today's general population (Underwood, 2006, 2011). Multiple supernatural and naturalistic explanations have been suggested to account for the sheer number of early Mormon visions and ecstasies, including rational supernaturalism (Erying, 1989; Park, 2008; Widtsoe, 1915), out-ofbody experiences (Bushman, 2006; Fillerup, 1996), animal magnetism or Mesmerism (Bunker \& Bitton, 1975), prophetic charisma (Foster, 2005), dissociation secondary to childhood trauma (Morain, 1998), enthusiasm associated with the Second Great Awakening (Staker, 2009, pp. 19-26; Taves, 1999), apparent materialization of the sacred during trance (Taves, 2014), pious fraud (Vogel, 2004, p. vii), and automatic writing (Dunn, 2002). However, no single explanation has to date successfully accounted for the number and quality of visions in early Mormonism. Nor can these modalities explain the "on-demand" visions that were neither spontaneous nor the result of prolonged austerities. To date, Joseph Smith's and early Mormon converts' visionary experience are neither easily defined nor understood (Waterman, 1999).

Against this background, we present compelling evidence suggesting that many early Mormon visionary experiences were facilitated by entheogenic substances that resulted in mood elevation and heightened spiritual awareness among early Mormon converts. In this entheogenic working hypothesis of early Mormonism, we consider the supernatural as natural (Taves, 2014; Winkelman \& Baker, 2015) and entheogens as medical therapy (Rucker, Jelen, Flynn, Frowde, \& Young, 2016; Winkelman, 2001; Winkelman \& Sessa, 2019). Because the two largest factions of Mormonism have opened their libraries to everyone (Spencer, 2009) and "primary source materials are so abundant and available, far more so than for more ancient religions" (Mason, 2015, p. 22), Mormonism may provide insight into the role entheogens played in the early success of traditional religions (see Richards, 2016; Winkelman, 2010, 2013).

\section{Visionary experience as veridical}

Converts who reported angelic visitations, ecstasies, and visions of God in 19th-century Mormonism regarded their experiences as veridical and not as imaginary constructs of the mind. The 19th-century publication, The Essential Guide to Datura (“Essential," n.d.), describes the subjective visionary experience of datura intoxication as "widely perceived to be real." In reviewing firsthand reports of early Mormon visionary experience, we find overlaps of these

\footnotetext{
*The authors have made minor spelling and grammatical corrections to some quotations to clarify writing errors.

** Corresponding author: Michael Winkelman, PhD; Caixa Postal 62, Pirenopolis, Go. 72980-000, Brazil; Phone: +1 623239 1662; E-mail: michaeljwinkelman@gmail.com
}

This is an open-access article distributed under the terms of the Creative Commons Attribution-NonCommercial 4.0 International License, which permits unrestricted use, distribution, and reproduction in any medium for non-commercial purposes, provided the original author and source are credited, a link to the CC License is provided, and changes - if any - are indicated. 
with contemporary accounts of visions facilitated by entheogenic substances, and with known symptomology associated with entheogenic use.

Defenders and critics of Mormonism may misunderstand this paper's thesis as questioning the validity of Mormonism's founding visionary experiences. Nothing could be further from the truth. All human experience and insight emerge in the chemistry of the brain, including the achievements of mathematics, science, epistemology, and even morality. To explore how brain chemistry was involved in Joseph Smith's religious experiences and those of other early Mormon believers and whether entheogens facilitated those experiences is not to question the spiritual validity and power of those experiences but to illuminate how such compelling experiences were accessed then and draw implications for how they may be accessed now. If the preponderance of evidence leads to the conclusion that entheogens facilitated many of Smith's visionary experiences and those of many early Mormon converts, then another oddity of the rise of Mormonism is explainable, the dramatic decline in reported visionary experience after Joseph Smith's death.

\section{Entheogens as authentic mystical experience}

Clinical research with entheogens (psychedelics) indicates that while they produce varying experiences, they also produce mystical experiences indistinguishable from those produced by non-drug means (i.e., prolonged meditation; see Griffiths, Hurwitz, Davis, Johnson, \& Jesse, 2019; Griffiths, Richards, McCann, \& Jesse, 2006; Richards, 2016). A double-blind study in the 1960s with students at the Harvard Divinity School (Pahnke 1963, 1966) found those sessions facilitated by psilocybin-reported experiences ranked, immediately and decades later, as among the most profound and life-shaping spiritual experiences in their lives (also see Doblin's, 1991 follow-up study). Richards (2016) reviewed this and other clinical research and examined their implications for issues in religious studies. The profound and undeniable implications of entheogens are their ability to produce genuine mystical experiences that are phenomenologically indistinguishable from the mystical experiences that result from devoted spiritual practices or which occur spontaneously. The clinical research establishes that it is pharmacology rather than personal expectation alone that enables entheogens to produce the standard core mystical features such as union with and intuitive knowledge of God, a sense of transcendence of time and space, a connection with sacredness, a sense of ineffability, and positive mood. This direct encounter with primal religious and mystical experiences provoked by entheogens has profound implications for religious studies in general (Smith, 2000, 2001), and as we will show here, for our understanding of the sacred visionary experience of early Mormonism.

\section{Context of Mormon entheogens}

Two salient characteristics of the early Mormon religion, founded by Joseph Smith (Figure 1) in 1830, were: (a) converts who were "seekers" whose "greatest hunger was for spiritual gifts like dreams, visions, tongues, miracles, and spiritual raptures" (Bushman, 2005, p. 147); and (b) converts who would sacrifice everything they possessed, even their own lives, and those of their family, to gather together, establish cities, and build temples to create a New Jerusalem, or Zion in America. While new religions were prevalent in the 19th-century America, the zeal with which Mormons defended their religion speaks to the charismatic power of the founding prophet, a charisma which may have leveraged entheogens for chemically induced spiritual awakening. We propose that the entheogenic context of early Mormon involved sacraments, ordinances, and endowments feeding these seekers' hunger for primary religious experience.

Discovering their yearning could be satisfied in Mormonism, seekers flocked to Joseph Smith (Figure 1), swelling Church membership from a mere 6 in 1830 to 8,000 living in Nauvoo by 1844 rivaling Chicago in population size (Hoyt, 1933, p. 50). Critical to the rise of convert numbers that the Church experienced was that between 1830 and 1836, seeker converts participating in Mormon rituals in which sacraments were ingested or anointing oils applied, had the dreams, speaking in tongues, miracles, and spiritual raptures they sought, with many enjoying visions of God and Jesus Christ (Anderson, K. R., 1996, 2012; Petersen, 1975, pp. 80-81). The experiences surrounding the dedication of the Kirtland temple in 1836 have been called the Mormon Pentecost (Olmstead, 2000), and had a similar impact on the rise of early Mormonism as the early Christian Pentecost had on the rise of Christianity; both

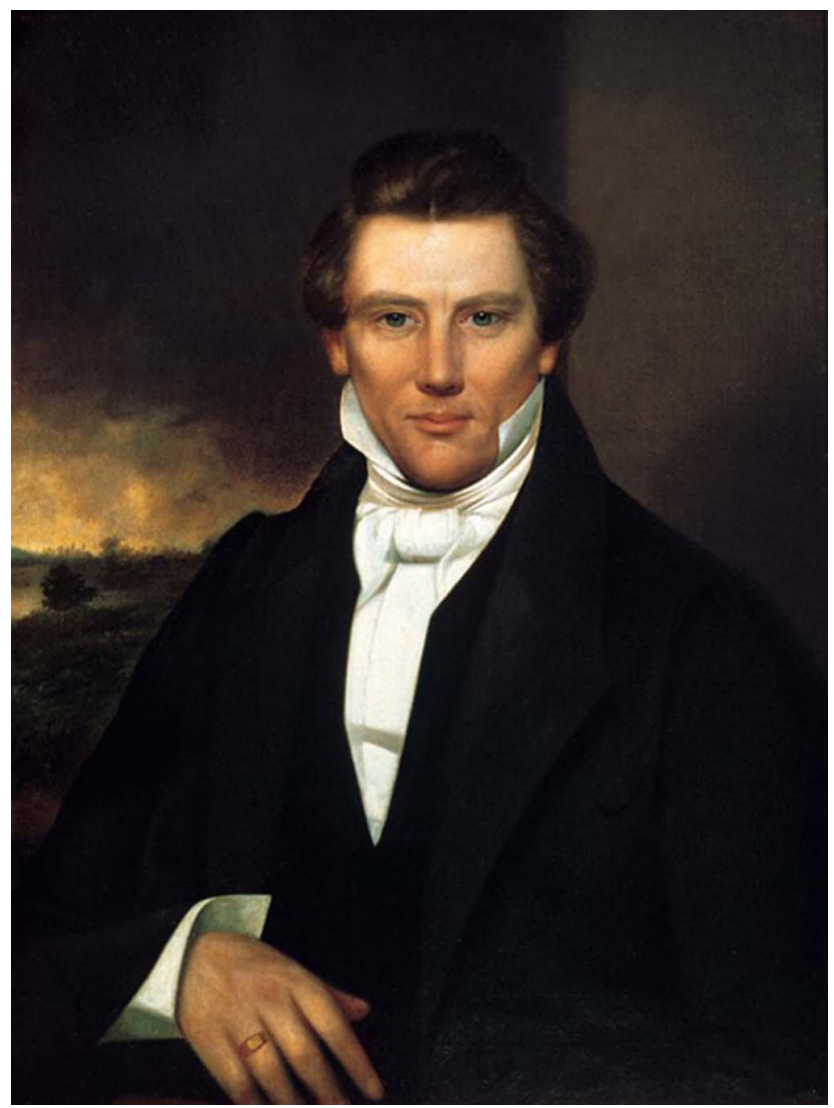

Figure 1. Painting of Joseph Smith, ca. 1842. Community of Christ. Public domain 
sects faced the same charges of drug-related visions (see Acts 2:1-31, "KJV").

Sectarian observers were appalled by the strange behaviors associated with visionary sacrament meetings that Mormons had opened to the public. Of this period, the Cleveland Harold \& Gazette reported:

Large [Mormon] meetings, continued for successive days, were held - earnest preachings and alarming exhortations were given ... swoons, trances, jerkings, and visions were frequent ("The Mormons," 1839)

A non-Mormon medically trained observer, James J. Moss who witnessed several meetings concluded that the strange behaviors and visions were produced by drinking "medicated" sacramental wine and contemplated stealing a bottle "to see if it were drugged or not" (Moss, 1878). Importantly, Moss, who was a believing Campbellite and had witnessed Methodist enthusiasm during the same period, distinguished between characteristic religious enthusiasm and sensational early Mormon visionary experience. Although Joseph Smith was not present at these meetings, he attended subsequent meetings where the sacrament produced similar bodily manifestations (Bushman, 2005, pp. 156-157). In response to the multiple complaints generated by the strange behaviors of Mormon enthusiasts, Smith closed sacrament meetings to outside observers, restricted attendance to male members only, added anointings with oil, and began construction of a temple in Kirtland, Ohio. During the dedication period of the Kirtland temple in early 1836 , en mass visions were once again reported by many of those who participated, with the same accusations of drugged sacramental wine (see below).

The evidence for Joseph Smith's use of entheogens explained in detail in this paper is primarily based on six straightforward phenomena reported or observed during the life of Joseph Smith.

1. Entheogens were found in every area the Smith family resided, and produce visions, and spiritual ecstasies.

2. Joseph Smith was mentored by individuals with experience in esoteric fields of knowledge.

3. Visionary experience in early Mormonism was frequently "on-demand" rather than spontaneous.

4. Joseph Smith devised a method to facilitate dramatic religious experience among his followers (Welch \& Carlson, 2005).

5. There was an association between early Mormon visionary experience and participation in Mormon ordinances where bread and wine were served, and oil anointings were received.

6. Visionary experiences of the magnitude experienced during Joseph Smith's life ceased at his death.

We find the best explanation for these phenomena is Joseph Smith's personal use of entheogens and his administration of entheogens to early Mormon converts.

\section{Entheogens as the "means"}

In contrast to traditional Christianity, Smith consistently understood matter and the body to be sacred, not profane. For Joseph Smith, the physical did not impede the spiritual but was instead the route to the spiritual. This unique aspect of Joseph Smith's theology and prophetic practice finds expression in his doctrine of "means." In Smith's theology, divine action operates through the instrumentality of material causes, including human action and natural law. The Book of Mormon raises this idea to the status of a general law of divine action, asserting: "The Lord God worketh through means" (Smith, 1830, p. 236, emphasis added).

Joseph Smith's doctrine that God operates by "means" and that the physical is a gateway to the spiritual provides a theological rationale for using entheogenic herbs and fungi. In the view of some prominent Mormons, entheogens are not prohibited by Joseph Smith's dietary "word of wisdom" (see below). Such entheogens would be physical means God has provided for humankind to achieve spiritual ends. Smith's approach anticipated recent developments in the study of religion, particularly the role physical process plays in religious experience. In this, Smith seemed to anticipate Edward O. Wilson, professor of biology at Harvard and one of the world's leading experts on biological diversity, who concluded that "we have come to the crucial stage in the history of biology when religion itself is subject to the explanations of the natural science" (Fuller, 2008, p. 4).

Joseph Smith likely understood that entheogens were a trigger for religious experience, a fact vindicated when considering entheogens as simple molecules cannot create the richness of early Mormon visions and ecstasies without the human capacity for religious experience. Instead, the religious experience is a product of the body through the actions of endogenous and exogenous neurotransmitters on human cognition. Mormons regularly modify their physical chemistry to promote spiritual experience through the Mormon practice of monthly prayer and fasting, but this is an unreliable method of inducing a transcendent spiritual experience of the nature experienced at the foundation of Mormonism.

In Smith's (1835) "the Word of Wisdom," he overtly endorses the use of one mind-altering substance for spiritual ends, wine in the sacrament of communion (D\&C 89:5). The revelation further teaches that "all wholesome herbs God hath ordained for the constitution, nature, and use of manevery herb in the season thereof, and every fruit in the season thereof; all these to be used with prudence and thanksgiving" (D\&C 89:10-11). Adherence to the prohibition of addictive substances and the use herbs carries the promise of "wisdom and great treasures of knowledge, even hidden treasures" and protection from the "destroying angel" (D\&C, 89:19-21). Herbs were a physical means to profound religious experience, experiences that rarely occur without using entheogens. As we discuss, evidence suggests that Smith gained knowledge and skill in working with herbs (D\&C, 42:43; 59:17-18; 89:10-11; Haller, 2000; Heinerman, 1975), including entheogens. Joseph Smith's grandson, Frederick M. Smith, came to the same conclusion as discussed below.

Joseph Smith was also a restorationist and advocated a unique form of Native American "restoration" or "revival. From its title page onward, The Book of Mormon advocated a "restoration" of Native temporal and spiritual power and Smith sought alliances with Native Americans and traded objects of spiritual significance with them. If Smith learned 
of entheogens that bore the imprimatur of Native American shamanism, he would have been likely to seek mentors in their use, not only for himself but also for converts of his Church. Besides facilitating religious visions and spiritual ecstasies, entheogens have remarkable antidepressant properties, suggesting a motivation, possibly unconscious, for their use by the Smith family and in early Mormonism.

\section{Wholesome herbs God hath ordained}

That Joseph Smith did not consider entheogens a problem is evident from his attitudes toward herbs. Joseph Smith knew of herbs and their uses and claimed the requisite knowledge and skill to devise and prescribe herbal remedies for others (Heinerman, 1975). Joseph Smith's development into a village scryer or "seer" involved following the path set forward in several esoteric traditions of the area he grew up, and possibly from his interpretation of biblical passages indicating the ingestion of some material preceding the visions of Ezekiel and John as discussed below.

In line with other health edicts of the 19th century, in 1835, Joseph Smith delivered a revelation called "The Word of Wisdom" suggesting dietary practices and the proper and improper use of alcohol, tobacco, and other substances. However, Smith carved out an exception for plant and herb medicine in the Word of Wisdom.

And again, verily I say unto you, all wholesome herbs God hath ordained for the constitution, nature, and use of man. Every herb in the season thereof, and every fruit in the season thereof. All these to be used with prudence and thanksgiving (Smith, 1835)

The first "anti-Mormon" book, Mormonism Unvailed [sic] by Eber D. Howe (1834), attributed the exemption carved out for "herb [s] in the season thereof" to Frederick G. Williams' influence on Joseph Smith (discussed below). Howe referenced Williams' herbarium on either side of his Kirtland home while disparaging his "communion with spirits from other worlds." Howe continues,

We are next told that every wholesome herb, God ordained for the use of man!! and we should infer that the writer or the recording angel had been inducted into the modern use of herbs, by the celebrated Doctor. F. G. Williams in Kirtland. F. G. Williams is a revised quack, well known in this vicinity, by his herbarium on either side of his house; but whether he claims protection by right of letters, patent from the General Government, or by communion with spirits from other worlds, we are not authorized to determine. (pp. 229-230)

The Smith family exemption of entheogenic herbs as prohibited substances in the Word of Wisdom seems generational considering that Joseph Jr.'s grandson Frederick M. Smith, also a prophet to the Reorganized Church of Jesus Christ of Latter Day Saints, carved out a similar exemption for peyote as discussed below. We begin by examining the historical setting of entheogenic practices of Joseph Smith Jr. and his ancestors, mentors, and colleagues. We then summarize the evidence for the entheogens available to Joseph Smith and his mentors, followed by descriptions of early Mormon visions and ecstasies we correlate with a clinical syndrome suggestive of intoxication with visionary anticholinergic substances.

\section{HISTORICAL SETTING: ANCESTORS, MENTORS, AND COLLEAGUES}

For Joseph Smith to fulfill his promise that every Mormon convert would have visions of God and spiritual ecstasies, he needed assistance from trusted associates who would covertly procure, process, store, and administer entheogens. Several early church leaders (including the Smiths, Cowdery, and Whitmer families in particular) were deeply invested in the study of occult practices, and herbal, plant, pharmaceutical, folk medicine /craft, and the utilization of "spirituous liquors" (Brooke, 1996; Quinn, 1998).

\section{Salem witch trials}

The Smith family involvement with the magic world view and possibly entheogenic material went back several generations. For instance, the Smiths were involved with the witch trials in 17 th century Salem, Massachusetts, that may have been instigated by the psychedelic ergot fungi (Claviceps purpurea). Samuel Smith, Joseph Smith's great grandfather, gave testimony in April 1692 that Mary Easty threatened him after which he reported, "I received a little blow on my shoulder, and the stone wall rattled very much" (Smith, 1692). After the Salem trials, other generations of his ancestors resided in areas noted for beliefs and practices of folk magic and alchemy (Quinn, 1998, p. 31). European occultism also shaped the cultural milieu in which the witch trials occurred. Mormon historian B. H. Roberts noted, "Indeed it is scarcely conceivable how one could live in New England [in the 18th-19th centuries] and not have shared such beliefs" (Quinn, 1998, p. 29).

The hypothesis of ergotism as the culprit in the Salem witch trials of 1692 (Caporael, 1976) is based on the signs of convulsive ergotism including seeing apparitions, feeling pinpricks, pinches, burning sensations, and by symptoms of urinary obstruction. However, those afflicted had none of the constitutional symptoms or residual effects known to occur with ergot poisoning (Woolf, 2000), making poisoning by ergot-infected rye bread less likely. The manifest symptoms were attributed to potions made by Tituba, a South American Arawak Indian or Caribbean enslaved person (Albanese, 2005; Breslaw, 1996) owned by the Reverend Samuel Parris (Dannaway, Piper, \& Webster, 2006). Tituba was familiar with Hoodoo religion (Martin, 2006) and plant medicines from her African heritage and could have prepared an anticholinergic such as datura (Caporael, 1976). This could have produced the symptoms ascribed to Parris' daughter, and her cousin, the first "bewitched" inhabitant of Salem, whose behaviors, resembled the anticholinergic toxidromal (Holstege \& Borek, 2012) and dissociative features of Hallucinogen Persisting Perception Disorder (Martin, 2006). 


\section{Joseph Smith Sr.}

The founding prophet of Mormonism, Joseph Smith Jr., was born on the December 23, 1805 into a Christian family enmeshed in folk-magic and the occult (Quinn, 1998). Joseph Smith's father, along with his other sons Alvin and Joseph Jr., engaged in the "more esoteric components of the western New York religious-cultural situation" (Shipps, 1987). Joseph Smith's earliest mentor was his father, who we believe would have communicated his entheogenic and magico-religious knowledge to his sons.

\section{Ginseng extraction}

Joseph Sr.'s knowledge of preparing plant extracts was recorded in 1811 when he collected and crystallized the 2018 equivalent of $\$ 57,000$ worth of ginseng root (Figure 2) intended for sale in China (Smith, L. M., 1853, p. 49). Administration of ginseng root extract compares well with Modafinil, a widely prescribed pharmaceutical drug used to treat "excessive daytime sleepiness associated with narcolepsy or shift-work" (Neale, Camfield, Reay, Stough, \& Scholey, 2013). Having crystallized and likely made use of this psychoactive themselves, the Smith's would have had no difficulty collecting, processing, and storing more potent psychoactive plants and fungi for their medicinal and magico-religious practices.

\section{Family magical practices}

Quinn (1998) has argued that the Smiths, who lived in Vermont, New Hampshire, Upstate New York, and Northern Ohio, engaged several magico-religious practitioners of which Luman Walters (discussed below) played a significant role as mentor to both Joseph and his father (pp. 98-135). The Smith family, including Joseph Jr., possessed and employed several magic-related artifacts including astrological charts, magical parchments, a ceremonial dagger, an alchemical amulet, a silver Jupiter talisman, and a cane that all "manifest direct indebtedness" to occultists including Sibly, Scot, Agrippa, and Barrett (Quinn, 1998, p. 118). Quinn characterizes these occult books of "enormous significance" to the Smith family,

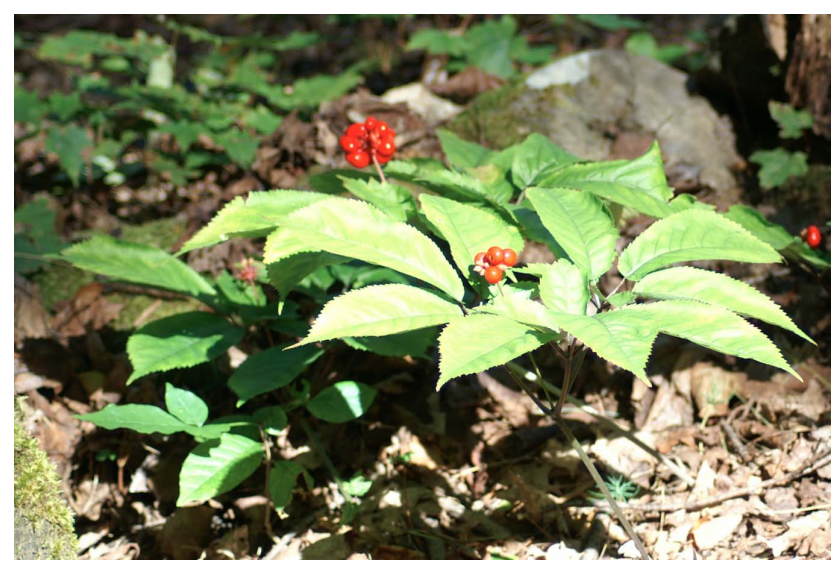

Figure 2. Ginseng found near the old Smith family farm, Sharon, Vermont (photo by Robert Beckstead)
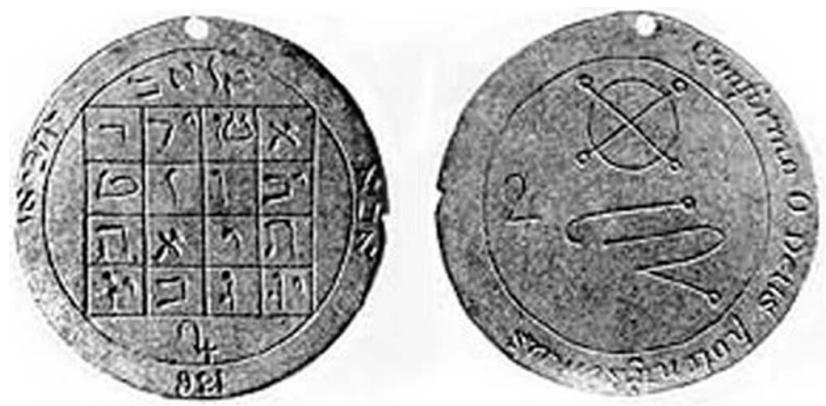

Figure 3. Joseph Smith's silver Jupiter talisman, after Barrett's The Magus (courtesy of Signature Books)

especially Joseph Jr. whose cane was inscribed with symbols from The Magus conveying the message: "Jupiterreigns over-Joseph Smith" (Ibid). Shown in Figure 3 is the silver Jupiter talisman also bearing the markings of Jupiter.

Joseph Smith Jr. possessed a Jupiter talisman, and a cane with a carved "serpent," a character in the Edenic allegory, and one animal believed to be "governed by both Saturn and Jupiter;" this, Quinn argues, shows that Smith relied on the works of occultists Francis Barrett and Heinrich Cornelius Agrippa (Quinn, 1998, pp. 90-91). Agrippa (1486-1535) names henbane, mandrake, and black poppy as three herbs "under the power of Jupiter" (Agrippa, 1801). According to Barrett (1801, pp. 89-92), henbane and black poppy are among the herbs used to invoke the "images of spirits" through proper suffumigations involving hemlock, henbane, black poppies, mandrake root, and other plants. Also, Joseph Smith possessed an esoteric Amulet (Quinn, 1998, p. 93) that seems to bear symbols belonging to both alchemy and masonry and representing Psilocybe species mushroom, which we discuss below.

\section{The visions of Joseph Smith's parents}

In 1853, Joseph Smith's mother, Lucy Mack Smith, related several family dreams in her book, Biographical Sketches of Joseph Smith, the Prophet, and his progenitors for many Generations and from which we learn about Joseph Smith's life growing up in the magically and religiously charged environments of sparsely populated New England and Upstate New York.

\section{Lucy's first vision}

The golden Amanita muscaria could be the mushroom that best fits Lucy Smith's remarkable first vision. Lucy's dream occurred c. 1802-1808, at least 3 years before her husband's two dreams in 1811 (described below) and 12 years before her son's first vision. Joseph Sr. had just informed Lucy it was best for her to "desist" attending the Methodist church because his father and older brother were very displeased. Lucy related that "after praying for some time ... [she] fell asleep and had the following dream" in which she saw trees that "were very beautiful, they were well proportioned, and towered with majestic beauty to a great height... I saw one of them was surrounded with a bright belt, that shone like burnished gold, but far more brilliantly" (Smith, J., 1853, pp. 54-55). 
A. muscaria occasionally forms "fairy rings" around the host tree (Figure 4), and the color of a mature A. muscaria, as shown in Figure 5, "takes on a metallic sheen ranging in color from red-orange to golden or bronze" (Heinrich, 2002, p. 14), a feature enhanced by early morning or evening light. Further, aging and drying converts ibotenic

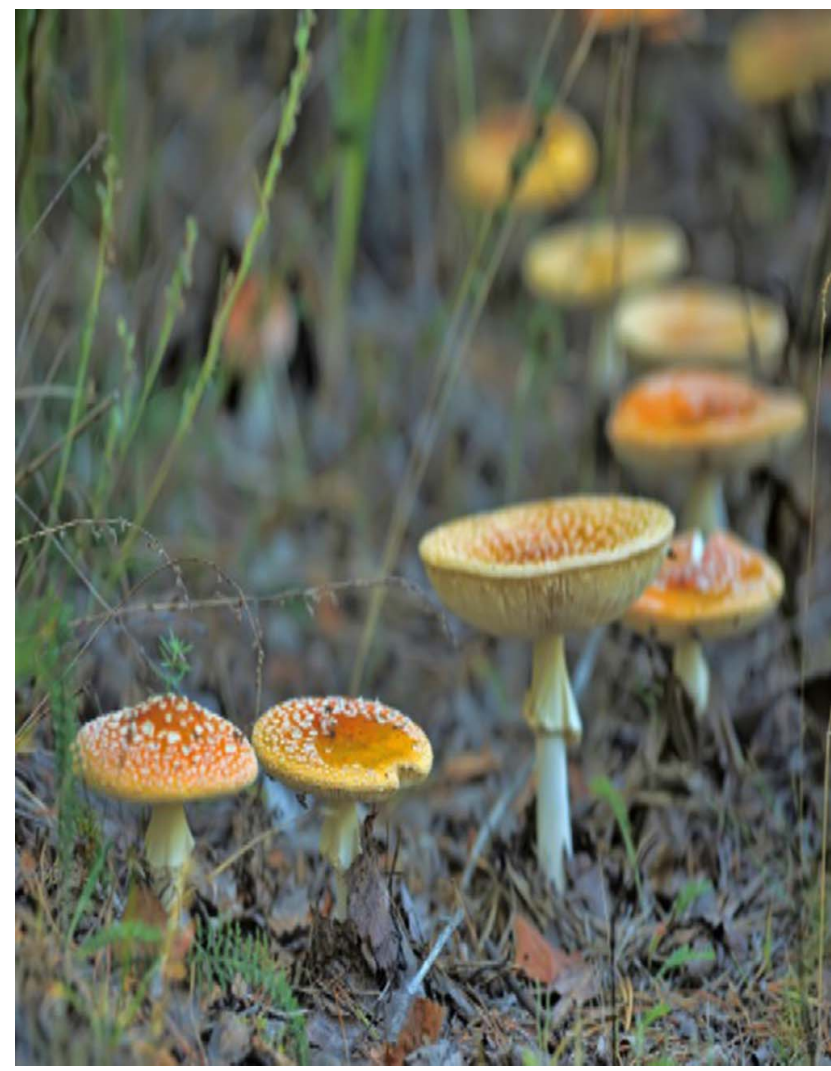

Figure 4. Ring surrounds a host tree (not shown) Shutterstock

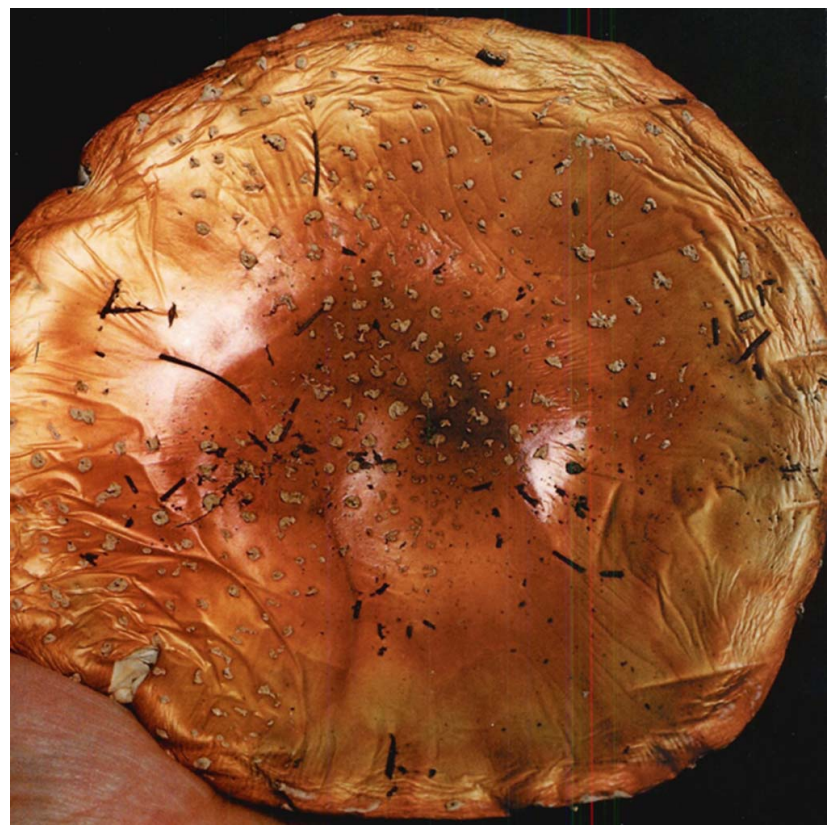

Figure 5. Mature, Burnished Golden A. muscaria (photo by Heinrich, 2002) acid to the more hallucinogenic and less toxic muscimol and "once completely dry, the golden mushroom's power is complete" (Heinrich, 2002, p. 170). A golden A. muscaria surrounding its host tree may have been one of Lucy's waking memories and incorporated into this dream.

Lucy's dream ended with her mood lightened as she concluded that her husband would share her feelings, when "more advanced in life, would ... rejoice therein; and unto him would be added intelligence, happiness, glory, and everlasting life" (Smith, L. M., 1853, p. 56). Lucy's dream included a conscious memory of having seen a "burnished gold" ring probably of $A$. muscaria. If Lucy deliberately tried this entheogenic fungus, she may have done so as treatment for her lifelong depression (Groesbeck, 1988).

\section{Joseph Smith Sr. 's first vision}

Two dreams reported by Joseph Smith Sr. strongly suggest experience with entheogens whose content contains not only allisions to entheogens but also some familiarity with esoteric allegory and symbolism.

Datura dream. In what his wife described as his "first vision," Joseph Sr. found himself entirely alone, although accompanied by an "attendant spirit." In the "desolate field," before him, Joseph Sr. saw only dead, fallen timber, and heard only "deathlike silence." Querying his attendant spirit on the meaning of such desolation and dreariness, Joseph Sr. was told that ahead he would find, "a certain log a box, the contents of which, if you eat thereof, will make you wise." Shortly after "tasting" the contents, Joseph Sr. reports being threatened by "all manner of beasts ... bellowing ... most terrifically." In the panic, Joseph Sr. escaped on the "fly," and when he returned to his natural senses, Joseph $\mathrm{Sr}$. found himself "trembling." Despite the frightful experience, Joseph Sr. reported being "perfectly happy" (Smith, L. M., 1853, p. 57).

The following datura experience posted online is impressive for its robust emotional impact, the overlay of visionary material on everyday reality, and the generation of a different reality.

You effectively keep your rational, sober mind along with your ego while on Datura; it's rather that your sober mind is experiencing a completely different reality. Imagine normal sobriety but as you start to dream while awake. Rather than enlightenment through ego death, the nightshades offer dimensional travel to other planes of reality (deCypher, 2008)

The frightening aspect of Smith's dream suggests a waking experience with datura fruit and his memory of the biblical warnings of death ("thou shalt surely die") associated with the "tree of knowledge of good and evil" (Genesis 2:17), coupled with his awareness of reports of fatalities associated with datura poisoning (e.g., Bigelow, 1817). Smith's guide echoes the serpent in Genesis 3:3, who advises that eating of the fruit "will make you wise." An element of Joseph Sr.'s first dream reappears in his second dream, thorns. Significantly, thorns are introduced into the world, according to 
Genesis 3:3, because of the ingestion of the "forbidden fruit" of the tree, perhaps symbolically referencing the thorny mature datura seedpod. What then, was the knowledge that Joseph Sr. received from his spirit guide and his dreams? According to his wife, following his two dreams, Joseph Sr. "seemed more confirmed than ever, in the opinion that there was no order or class of religionists that knew any more concerning the Kingdom of God, than those of the world, or such as made no profession of religion whatever" (Smith, L. M., 1853, p. 60).

A. muscaria dream. The same year as the first dream, Joseph Sr. had a second entheogen-related dream, which involved basking in ecstasy, the joy, and love associated with the Edenic tree of life. In this dream, which he related to his wife Lucy, a psychopomp leads Joseph Sr. to a tree with, "beautiful branches spread themselves somewhat like an umbrella, and it bore a kind of fruit, in shape much like a chestnut bur, and as white as snow, or, if possible, whiter." As he watched, the chestnut "shells commenced opening and shedding their particles, or the fruit which they contained, which was of dazzling whiteness." When he partook of the fruit, he experienced something "delicious beyond description" and, inviting his family to eat, they "got down upon [their] knees, and scooped [the fruit] up, eating it by double handfuls" (Smith, L. M., 1853, p. 85).

In this dream, Joseph Sr. incorporates the spiny, thorny fruit of the chestnut, a feature of the first dream, which is similar in appearance to the fruit of datura. Instead of datura, however, the umbrella-shaped fruit scooped from the ground in the second dream evokes images of dazzling white spores dropping from the gills of an A. muscaria against a bright background or on a black surface.

Joseph Sr.'s esoteric Christian A. muscaria dream concludes with Joseph Sr. explaining to his wife, Lucy, "I drew near and began to eat [the fruit] of it, and I found it delicious beyond description. As I was eating, I said in my heart, 'I cannot eat this alone, I must bring my wife and children, that they may partake with me.' I went and brought my family, which consisted of a wife and seven children, and we all commenced eating, and praising God for this blessing. We were exceedingly happy, insomuch that our joy could not easily be expressed" (Smith, L. M., 1853, p. 85).

\section{Emma Smith}

Emma Hale, Joseph's wife, was gifted in using herbs. One of Emma's medicines was a healing salve that contained "jimson weed" or Datura stramonium (Bailey, 1952) and when the Sauk Indians visited Nauvoo in 1841, she exchanged recipes for herbal medicines with the wife of Chief Keokuk (Newell \& Avery, 1994). In 1867, Emma wrote to her son, Joseph Smith III: "I will tell you now how I make the salve. Of sweet elder bark a good large handful after it is scraped, and as much gymson [jimson] leaves and buds if they are green and tender enough to be pounded up fine" (Bidamon, 1867; Youngreen, 2001, pp. 97, 119). Emma's grandchildren also reported her use of psychoactive medicinal beer, ginseng, and lobelia, or "Indian tobacco" (Youngreen, 2001, pp. 73, 99). Ginseng has stimulant, antidepressant, and aphrodisiac properties, while lobelia (a hallucinogen and sedative) had entheogenic uses among Native Americans (Alrashedy \& Molina, 2016).

\section{Native Americans}

Smith always lived close to Native Americans and likely was influenced by shamanic activities. For instance, the Algonquin (Delaware, Fox, Ojibwa, Potawatomi, Sauk) in the Northeast and Great Plains, the Iroquois (Cayuga, Oneida, Onondaga, Seneca) in the northeast (Tooker \& Sturtevant, 1979, p. xviii) and the Cherokee in the southeast (Hamel \& Chiltoskey, 1975, p. 41) and their shamans resided close enough to Joseph Smith that he would have been captivated by their religious and medical practices.

In 1822 Seneca Indian Chief, Red Jacket, nephew of Chief Handsome Lake, spoke only miles from where Joseph Smith lived. Red Jacket might have sparked 17-year-old Joseph Smith's interest in Native American culture and seeking a Native American shamanic mentoring (Taylor, 2010).

Joseph Smith demonstrated his interest in Native American life at age 18 when he regaled his family with stories of ancient Indian life (Smith, L. M., 1853, p. 79), and later partially built his prophetic career on a Native platform with The Book of Mormon. Comparative religionist Åke V. Ström (1969) has demonstrated many parallels of Joseph Smith's teachings and practices with those of Native religions of Northeastern North America, especially that of the Algonquins. The parallels are extensive enough that Ström posits that the boy Joseph may have been heavily influenced by an Algonquin neighbor. Smith's Native American influences may have included North American entheogens, such as D. stramonium, A. muscaria, and Psilocybe species. The Native Americans used entheogens in medical and spiritual practices such as the Ojibway Midewiwin or Grand Medical Society. The Ojibway (Anishinaabe people) in their legend of Miskwedo described the use and effects of $A$. muscaria (Navet, 1988).

We summarize here the version told by medicine woman Keewaydinoquay Peschel (1979) where Miskwedo, the redtopped mushrooms, the spiritual children of Grandmother Cedar and Grandfather Birch. Two brothers came upon Miskwedo "turning and revolving, buzzing and murmuring, singing a strange song of happiness under a brilliantly sunny sky." The older brother tried to dissuade his younger brother from eating the mushroom, but defies his brother and merged with the mushroom, becoming a Miskwedo himself. Distraught, the older brother ran home to ask the medicine men what to do; and he was told to return, locate the chief and the wisest Miskwedo, and stick the quill of an eagle feather through each of their stipes to stop them turning and singing songs of happiness, then to do the same to his younger brother and carry him home. He followed the elder's instruction, and his younger brother turned back into his previous form. However, after returning home, the older brother arose in the morning "with his heart heavy with sadness and foreboding," while his younger brother "arose smiling each day, his heart filled with happiness, his lips singing merriment." The older brother became suspicious when, the younger brother urinated more frequently and took longer than before. When the older brother 
investigated, he found his younger brother with "arms are open wide, spread like the umbrella of a mushroom" with beautiful robes "glowing red, and tufts of white" singing with a "voice of happiness" to the "people following him." Now and forever, older brothers are unhappy in contrast to the younger brothers who "drink the Elixir of the Great Miskwedo" learning much of "the supernatural and other knowledge" by drinking "the liquid Power of the Sun."

Together, these stories transmit knowledge about $A$. muscaria, where to look for it, how to recognize it, the joys it can bestow, and the displeasure of authorities if consumed. For instance, these mushrooms are always associated with trees such as cedar and birch and have red tops with white tufts. The experience of ingesting these mushrooms includes transient ego disillusion, unity with the Divine, and mood elevations. The stories also warn of authoritarian displeasure, whom themselves refuse filling their hearts with happiness, try to suppress its use. In The Book of Mormon, Joseph Smith relates a similar story about Lehi's use of entheogens. Lehi comes upon a tree ladened with fruit that filled his soul "with exceeding great joy." However, others, whose dress was "exceeding fine," mocked, and pointed their fingers at those "partaking of the fruit." The scoffing caused some who ate from the tree to feel ashamed and fall "away into forbidden paths" (Smith, J., 1830, p. 20).

Midewiwin shaman are believed to possess the power of a long life, even "victory over death" through healing plants and the rituals. Such power strongly suggests that among other herbal remedies, the Midewiwin shaman utilized entheogenic material.

Delaware (Tantaquidgeon, 1972, p. 37) and Mohegan (Ibid, pp. 72, 128) peoples were familiar with datura. Native Americans living in Virginia gave a psychoactive brew called "wysoccan" to their young men during a rite of passage, causing a "derangement for 20 days," strongly suggesting it contained D. stramonium (Schultes, 1975, 9, 142) or $A$. muscaria (Geraty, 2015). Most North American Eastern Woodland Indian groups reported: "datura as the base of a narcotic drink used in manhood initiation rites" (Goodman, 1993). In 1705, Virginian Indians were reported to have been using datura in their religious ceremonies (Safford, 1922) and there was widespread use of datura in initiation ceremonies in Native North America (Jacobs, 1996). Further, sometimes, Eastern Native Americans would add "datura and other powerful substances ... to tobacco to prepare a particularly potent smoke" (Fuller, 2008, p. 81).

Growing up and into adulthood, Smith lived relatively near to the Algonquin areas of the Potawatomi, Ojibwa, and Delaware peoples whom all belonged to the Algonquin family. We will explore Smith's relationships with this group of peoples when we discuss his transactions with the Potawatomi in the early 1840s Nauvoo. However, it is enough to note that Smith likely noted the secretive Midewiwin medical society with its selective membership, graded training of new shamans, and their use psychoactive materials including datura and A. muscaria.

\section{Esoteric Christianity}

Joseph Smith was influenced at a young age by several categories of esotericism, including esoteric Christianity, spiritual alchemy, and speculative freemasonry (Owens, 1999). Significantly, some members of these esoteric schools of thought had an interest in entheogen use and encoded their knowledge in esoteric works of art.

During the 13th century, esoteric Christian artists painted Biblical themes associated with entheogenic mushrooms (Brown \& Brown, 2016; also see Brown \& Brown in this issue). For instance, in Figure 6 is an "Eden Panel" found in Saint Michael's Church, Germany (1240 CE) showing Adam and Eve standing, and a serpent coiled on a tree in front of a spotted A. muscaria mushroom cap. Also, in Figure 7, the Edenic tree also takes on the form of an $A$. muscaria in a ca. 1291 fresco found in Plaincourault Abbey, Indre, France. Figure 8 shows a painting by the Flemish artist, Petrus Christus (c. 1410-1475) portraying the child Christ laying supine on an A. muscaria bed looked over by

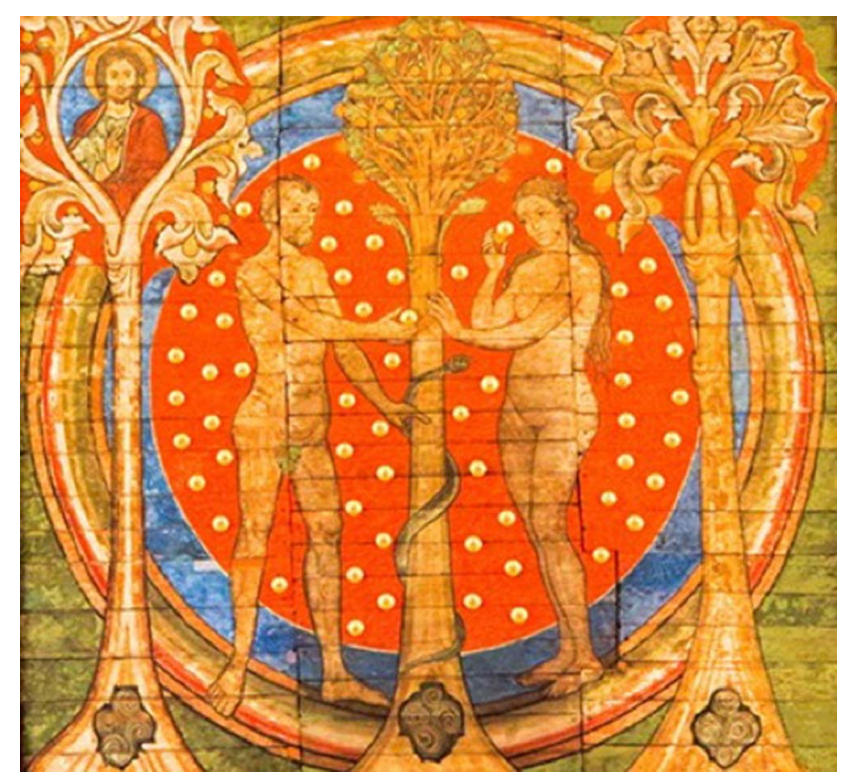

Figure 6. Eden Panel, St. Michael's Church Germany, 1240. Public domain

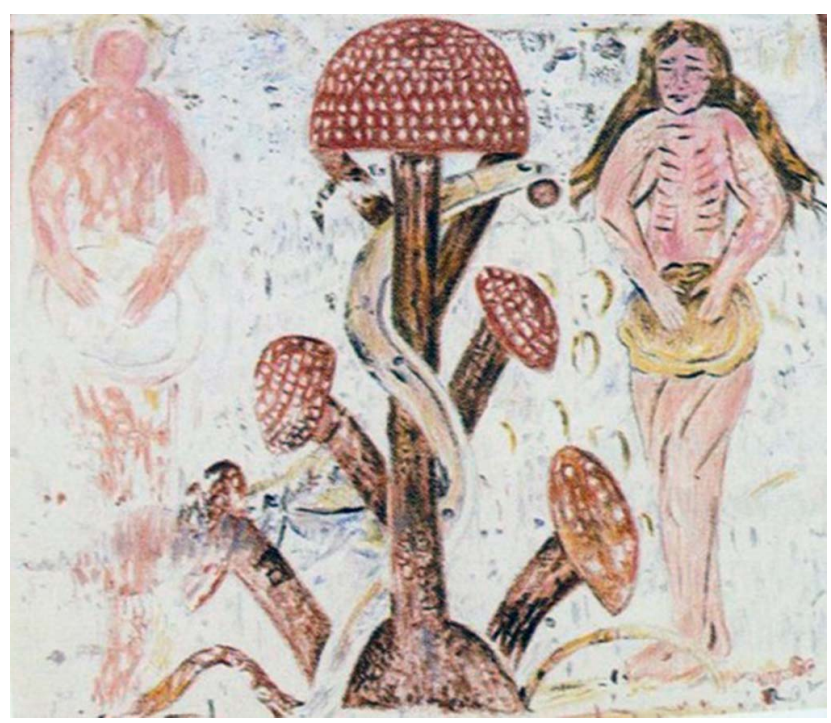

Figure 7. Temptation in the Garden of Eden, Plaincourault Chapel, France, $c a$. 1299. Color enhanced. Public domain 


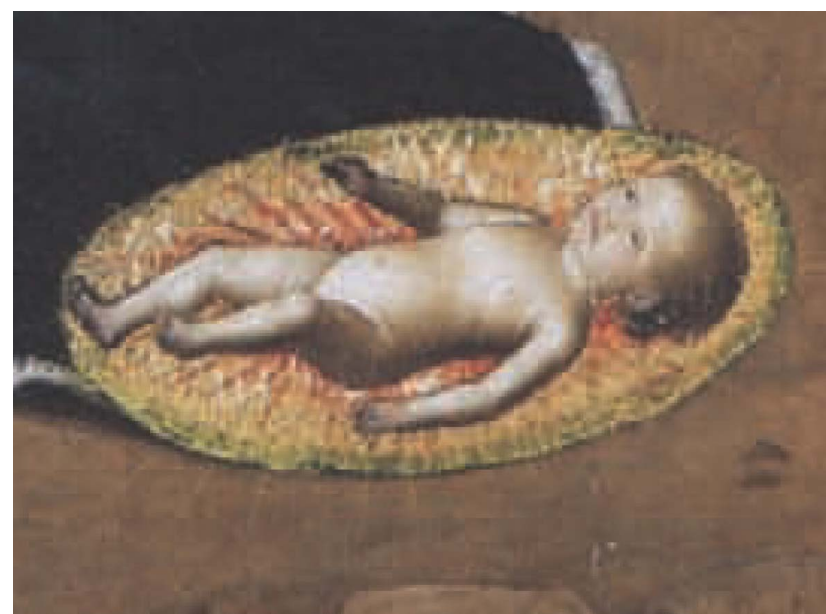

Figure 8. The Nativity, Petrus Christus, 1452 (only close up of infant Jesus is shown). Public domain

Joseph, Mary, and winged angels. The relative abundance of Christian A. muscaria syncretic art led Antonio Escohotado (2012) to conclude, "it seems indisputable that there is a connection between visionary mushrooms and Christianity" (p. 73). There are reasons to think that given his esoteric background, Joseph Smith or one of his mentors had access to this art, decrypted it, and then encoded in Smith's teachings, revelations, and ordinances.

Where then did Joseph Smith first learn of alchemy and esoteric Christianity? In his book, Magic Mushrooms in Religion and Alchemy, Heinrich (2002, pp. 105-153) discusses the relationship between esoteric Christianity and using A. muscaria as a sacramental meal. According to Heinrich, Jesus unmistakably identifies himself with an entheogenic substance, an elixir of life and bread of heaven, the A. muscaria mushroom shown in Figure 9. Heinrich quotes Jesus telling a woman,

... whosoever drinketh of the water that I shall give him shall never thirst; but the water that I shall give him shall

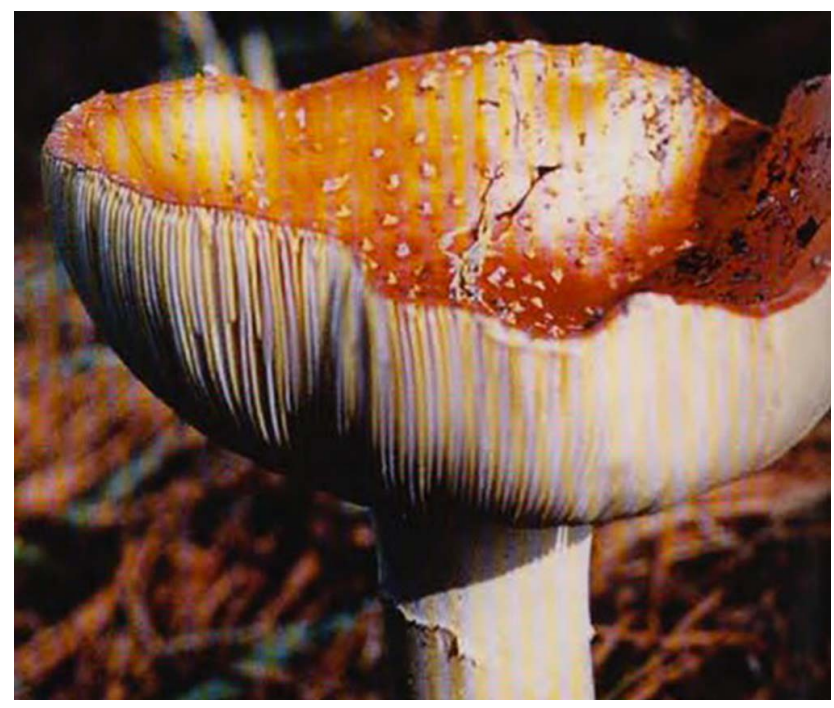

Figure 9. A. muscaria as elixir (blood of Christ) and bread (flesh of Christ) (photo by Heinrich, 2002) be in him a well of water springing up into everlasting life. (p. 120)

The "living water," according to Heinrich, is water-soluble muscimol, the principle psychoactive in A. muscaria. Muscimol is excreted unchanged in the urine, which the shaman or others can consume. Supporting Heinrich's argument of entheogenic urine, we note Jesus's saying in John 7:8,

He that believeth on me, as the scripture hath said, out of his belly shall flow rivers of living water.

The phrase "out of [Jesus'] belly" may describe entheogeniclaced urine. Due to physiological processes, urine after ingesting $A$. muscaria is more potent than the tea initially consumed. The entheogenic component of $A$. muscaria is water-soluble, and when extracted with water, turns the water the color of red wine. Further, the mushrooms upturned cap (Figure 9) and becomes the cup holding the elixir of life, and the mushroom itself becomes the life-giving bread. Heinrich (2002, p. 122) quotes Jesus telling he disciples:

I am the living bread that has come down from heaven. Anyone who eats this bread will live forever; and the bread that I shall give is my flesh ... if you do not eat [my] flesh and drink [my] blood, you will not have life in you. Anyone who does eat my flesh and drink my blood has eternal life ... for my flesh is real food and my blood is real drink ... As I, who am sent by the living Father, myself draw life from the Father, so whoever eats me will draw life from me. This is the bread come down from heaven ... anyone who eats this bread will live forever. (p. 121)

Implied in Heinrich's discussion of these passages is his confidence that anyone using entheogens in a Christian context will experience "many of the states described ... in mystical Christianity" (p. 5).

Although most of Smith's revelations and teachings suggest the traditional Christian understandings of Jesus, occasionally he betrayed a different view. For instance, in 1844, Smith is reported to have said,

I am the only man that has ever been able to keep a whole church together since the days of Adam ... Neither Paul, John, Peter, nor Jesus ever did it ... The followers of Jesus ran away from Him; but the Latter-day Saints never ran away from me yet. (Roberts, 1915, pp. 408-409)

In this statement, Smith seems to suggest that Jesus did not differ from him - meaning that Smith understood Jesus as shaman-like, as a human and not a God. Likewise, Jesuslike Smith healed the "lame arm" of Mrs. John Johnson (Dahl \& Cannon, 1997) and raised William Hungtington from the dead (Curtis, 1892).

\section{Spiritual alchemy}

Owens (1999) argues that Joseph Smith "certainly [learned]. . . about the Philosopher's Stone and alchemy's 
transmutational mystery" (p. 158). Alchemy became a subject of several artists in Europe. Owens argues that Smith likely learned about alchemy from "a physician named Luman Walter(s), who was a distant cousin of Smith's future wife and a member of the circle associated with the early treasure quests" (p. 16) of which young Joseph was a member. Agreeing with Owens, D. Michael Quinn reasons that Walters was Smith's teenage mentor and occult advisor (1998, pp. 116-122).

In his book, Science, Alchemy and the Great Plague of London William S. Shelley (2017) stated "that alchemical writings concerned chemical processes from their late antique beginning until the Renaissance. Spiritual alchemy originated, it would appear, in the early sixteenth century when Paracelsus [1493-1541] blended his medical practice of alchemy with his interest in the Hermetic-Platonic tradition of Renaissance esotericism" (p. 4). Sometime late in the reign of Queen Elizabethan (1533-1603), alchemical texts "seem to be exclusively spiritual, that is, that have no apparent interest in practical laboratory procedures" (Ibid).

English alchemists such as Elisa Ashmole (1617-1692) and Robert Boyle (1627-1691), according to Shelley, "were concerned with one or more substances, termed the red stone, the angelic stone, and otherwise, whose effects were described as spiritual." Shelley then argues, "these are substances that produced mystical experiences and was implicitly psychoactive" and associates it with "the motif of [Israelite] manna, ... the hidden manna of Revelation $2: 17, \ldots$ [the] hermetic tradition, ... English alchemical literature from the Tudor period onward," and in "the twelfth century theology of the school of Laon [northern France], afterward spreading to Cistercian, Franciscan, and other writers" (Ibid).

Heinrich (2002) explores the connection between alchemy and entheogens, including the allegorical use of the Rebis such as the one in Figure 10 to transmit privileged knowledge of entheogenic A. muscaria (pp. 172-177, 184). The Rebis is a double-headed hermaphrodite linked to the prima materia, philosophers stone, an elixir of life within the allegory, A. muscaria. According to Lewis Spence (1920, p. 10), one of the "grand objects of alchemy" was the discovery of an elixir to ensure health and prevent death, "elixirs of life" containing herbs and medicinals that Heinrich argues are entheogens.

We now examine an amulet in Figure 11 belonging to Joseph Smith and gifted to Eliza R. Snow, his most esoteric plural wife. Figure 12 shows an inverted mushroom species (presumably Psilocybin) comparing favorably to the mushroom-appearing tassels dangling from both the belt worn by the Rebis in Figure 13 and the belt engraved on Joseph Smith's amulet in Figure 14. It is reasonable to propose that Figures 11 and 13 represent the same thing, Psilocybe species mushrooms.

\section{Speculative Masonry}

Mormon historian and former director of the Institute of Religion in Salt Lake City, Reid C. Durham documented Joseph Smith's Masonic heritage and his adoption of Masonic ritual and iconography found in the Mormon Nauvoo temple endowment (Durham, 1974). The Nauvoo
Masonic Lodge, founded at the end of 1839, anticipated the spring of 1842 groundbreaking of the Nauvoo temple.

Joseph Smith's father and older brother, Joseph Sr. and Hyrum, respectively, were both Masons, and Joseph Jr. was likely familiar with Captain William Morgan, famously murdered for publishing the secrets of Masonry in 1826. After Morgan's death, his widow, Lucinda Morgan, secretly became one of Smith's 33 known plural wives in 1838 (Compton, 1997). Early Mormon leaders and successors to Joseph Smith, including Brigham Young, the leader of Mormonism's most successful schism, were deeply involved in Masonry before their conversion to Mormonism (Durham, 1974; Tanner, n.d.). There were masonic motifs, architecture, ritual, and iconography in the Nauvoo, Illinois temple. For example, on the outside architecture of the temple were the masonic sunstones, upside-down fivepointed star stones, moonstones, and a masonic compass and a square weathervane. Inside the temple, the masonic "all-searching eye" was shown on the original architect's drawing (Stack, 2002).

Joseph's mother, Lucy Smith (Anderson, 2001, p. 23; also see Joseph Smith Papers, 1844-1845) revealed how "for a season that we stopped our labor and went trying to win the faculty of Abrac," a secret masonic process with roots in much older traditions. Mormon scholar and historian Michael Quinn (1998) reports that the

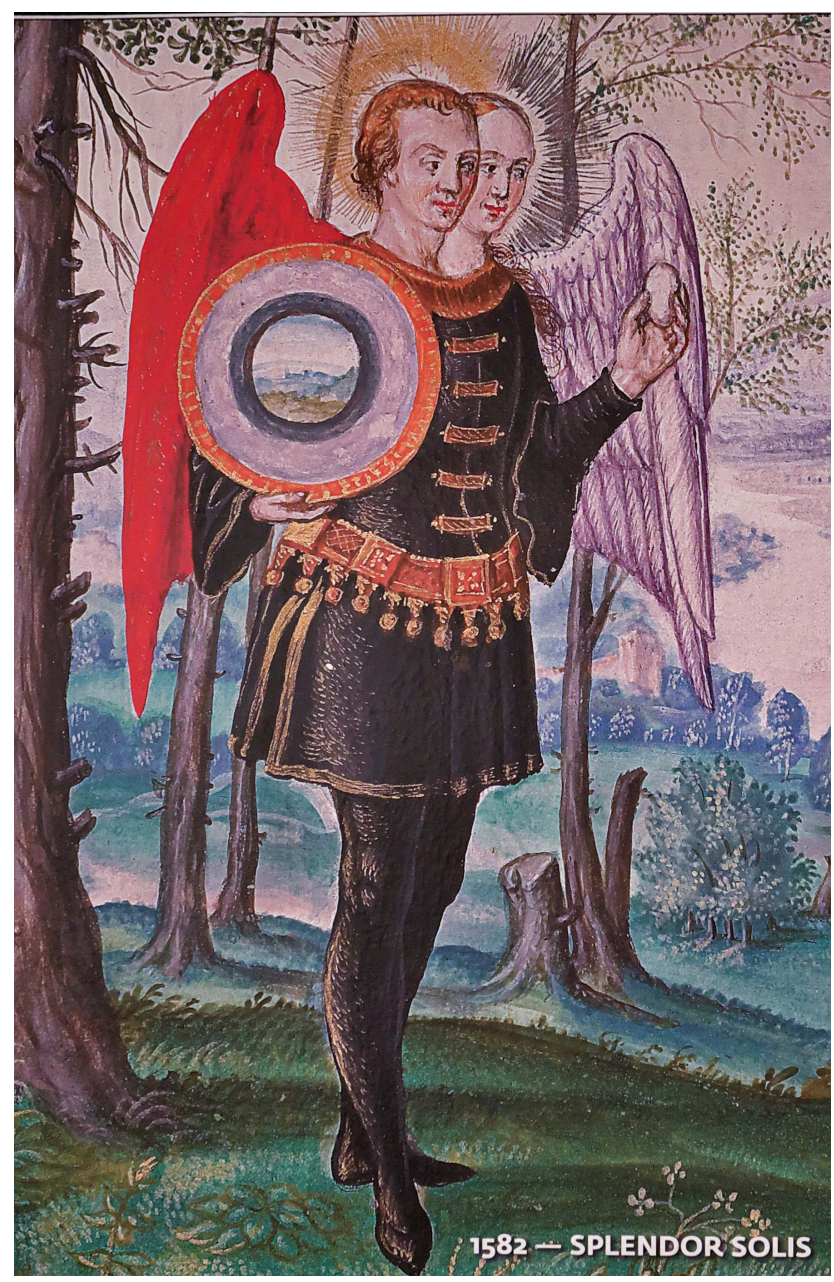

Figure 10. Rebis by Solomon Trismosis, 1852. Public domain 


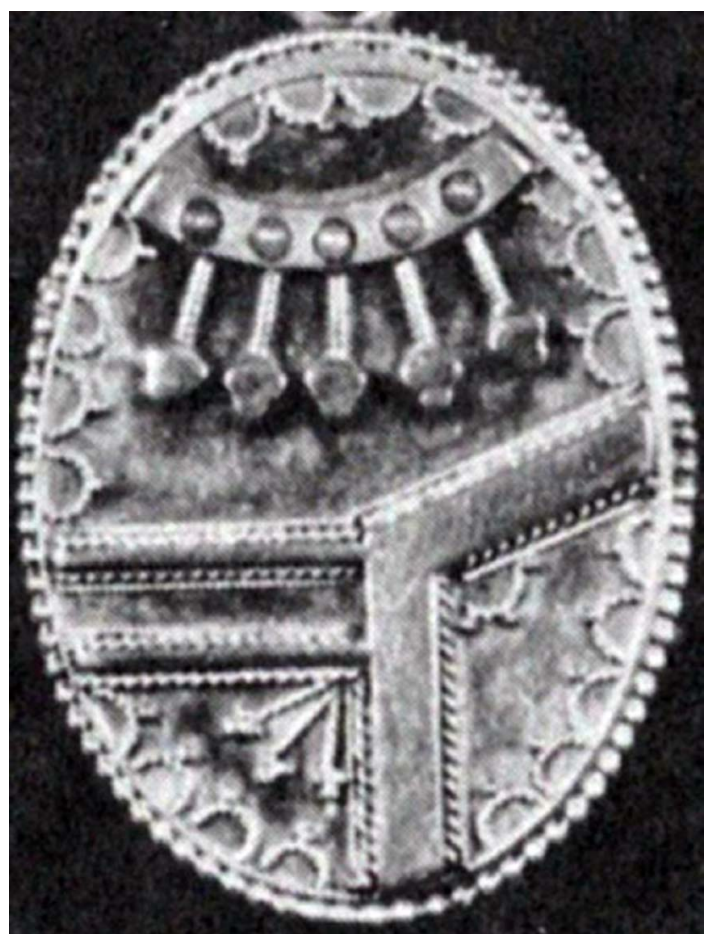

Figure 11. Joseph Smith's alchemical amulet (courtesy of Signature Books)

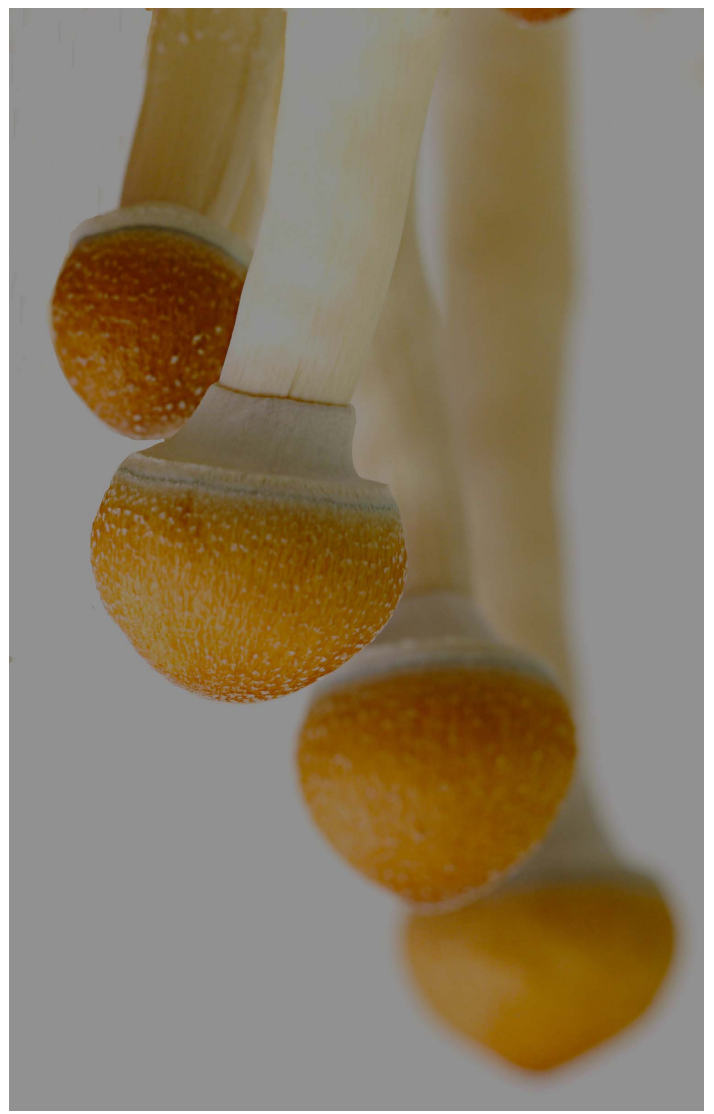

Figure 12. Inverted relatively young Psilocybe species mushroom (Shutterstock photo)

Faculty of Abrac was a well-known phrase linking magic and divinity. Medieval and early modern magic manuscripts in England used "Abrac" and "Abraca" as one

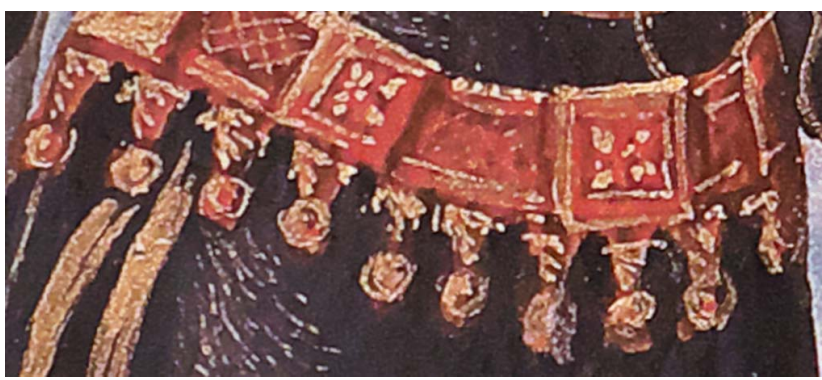

Figure 13. Enlarged belt on the Salomon Trismosin Rebis (adapted from Figure 10)

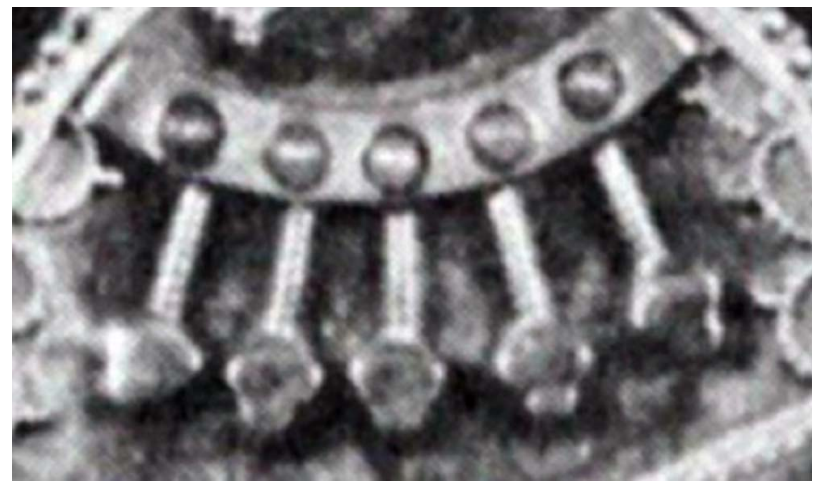

Figure 14. Enlarged belt on the Joseph Smith amulet (adapted from Figure 11)

of the names of God in conjurations. [And that] "Abraxas [was a] Gnostic name for God that had become associated with magic.” (pp. 68-67)

In America, as in Europe, speculative masonry subsumed many mysteries in the ancient world (Casey \& Gutierrez 2005, p. 222). There is evidence to suggest that these mysteries utilized entheogens including the Greek Eleusinian mysteries (Wasson, Ruck, \& Hofmann, 2008, pp. 2-7), the Demeter-Persephone cult (Ibid, pp. 12-15), and the Dionysiac mystery cults (Ibid, pp. 15-18). The Roman Phrygian rites for Magna Mater (Drummond, 2013, p. 46), the Mithraic cults of Persia (Ezdejini, 2016), and the mysteries surrounding the Egyptian gods Osiris and Isis (Berlant, 2005) are all suspected of entheogen use in their rites.

According to Chris Bennett (2018), the "imagery of the [Masonic] Lodge, was built with a set and setting that in many ways could be enhanced by the use of entheogens" (p. 681) and the idea that some "masonic drinks may be a remnant of early sacramental potions that contained psychoactive ingredients ... [has] been pondered for well over a century" (p. 693). For instance, Bennett quotes from an 1835 Masonic history by John Fellows who in rehearsing the entheogens of Ancient Egyptians, Pythagoreans, and Druids, "refers to a soporific cake of honey and medicated grain medicatis frugibus [i.e. drugged]) along with preparations of poppy and other psychoactive substances [with fellow Mason as] its target audience" (Ibid). Bennett then notes Fellow's informing the candidate that in drinking the potion offered to him during initiation, it is a eucharist by which "the real presence of the Saviour is manifest" (Ibid). 
In his book, Alchemically Stoned, the 33rd degree Mason P. D. Newman (2017) argues that features of Masonic ceremonies, architecture, and accouterments strongly suggest some Masonic lodges used entheogenic material from Acacia species known to contain the psychedelic dimethyltryptamine (DMT). Shannon (2008) and Nemu (2019; Editor's Note: see Nemu's article here) similarly argue for the Hebraic use of the entheogenic Acacia tree.

According to Mormon writer Jeffrey Bradshaw (2015), "In the ceremonies of the Royal Arch Degree of the York rite, candidates pass through a series of veils and eventually enter into the divine presence" (p. 162), but in the Nauvoo temple endowment, it "is not a mere representation but is the reality of coming into a heavenly presence" (p. 218). Mormon historian Andrew Ehat (1994) explains, "In temples, we have a staged representation of the step-bystep ascent into the presence of the Eternal while we are yet alive ... [and] "there should have been a change in us as there certainly was with Moses when he was caught up to celestial realms and saw and heard things unlawful to utter" (pp. 53-54, emphasis added). We argue that the "change" required to be "caught up to celestial realms" required the administration of an entheogen, a change that, like in Kirtland, would produce observable symptomatology. If this hypothesis is correct, an entheogenic endowment may have been the source of Smith's confidence that converts would in "reality" be "caught up to celestial realms." The secret that Smith needed converts to keep was the visible symptomology they would observe during the Nauvoo temple endowment.

\section{Policy of secrecy}

In an 1841 meeting, Joseph Smith explained a purpose of the lodge is to learn to keep secrets. Smith explained, "the reason we do not have the secrets of the Lord revealed unto us is because we do not keep them" (Roberts, 1908, p. 478) and later observed, "The secret of Masonry is to keep a secret" (Roberts, 1915, p. 59). What did Smith want to keep secret? Besides Smith's unusual marriage practice (Hales, 2015; Van Wagoner, 1985, 1989) and his kingdom building ambitions (Grow, Esplin, McGee, \& Mahas, 2016), we argue it was to keep secret administration of an entheogen in the endowment.

\section{Luman Walters, Occultist and eclectic physician}

Mormon scholar and historian Michael Quinn (1998) reviewed the historical record about Luman Walters (1789-1860), who was an accomplished physician, preacher, and magician. Through his travels and scientific training in France, Germany, and Italy, Walters became an "eclectic" physician whose practices involved occult techniques that included the administration of medicinal herbs he processed in his well-stocked laboratory. Walters was an exceptionally qualified mentor. During Joseph Smith's teen years and early twenties, Walters utilized his occult training as an astrologer and seer for treasure companies, one of which was a "fraternity" of rodsmen, with Joseph Sr. as one of the leading members. During this period, Walters was young Joseph's "constant companion and bosom friend" and given Smith's extraordinary level of intelligence, he readily received Walters' teachings and eventually exceeded his skills as a conjurer and scryer (Cole, 1831).

\section{Esoteric practice}

Walters used a seer stone, conjuration, animal sacrifice, and likely a hallucinogen to occasion "interview with the spirit, supposed to have the custody of [a particular] hidden treasure" (Quinn, 1998). It was Walters who "first suggested to Joseph the idea of finding a book." Occasionally, Walters could be found reading to a receptive audience from an "old book" in a language that only he could understand and prophesied that Joseph Jr. "was about to find ... a history of hidden treasures" and a "record of the former inhabitants of America" (Cole, 1831; Morgan, 2014).

Joseph Jr. was chosen as a treasure seer by the same company that had hired Walters, leaving him angry and resentful (Kane, 1995). Residents believed Walters' mantle fell on the young Joseph. While acting as a seer for this company, Smith announced that he found golden plates containing a history of Amerindian ancestors, from which he subsequently "translated" The Book of Mormon. Smith used a seer stone to translate, and we hypothesize an entheogen; the use of the latter is suggested by reports of his frequent "intoxication" or "altered" appearance while translating. Luman Walters and Joseph reconciled because Walters was later reported to be a "disciple" of Joseph Smith in Kirtland, Ohio, suggesting Walters' direct impact on Mormon visionary experience could extend into the early Kirtland period at least (Quinn, 1998, p. 131). Walters likely received his esoteric training, including alchemical-drug expertise while studying in Europe (see below). The esoteric physician's involvement in Mormonism was confirmed by Brigham Young, one of Joseph Smith's successors (Young, 1858). Joseph Smith's alchemical-masonic amulet suggests Walter's drug-alchemical influence in Smith's early career (see below).

\section{Medical practice}

Walters' medical practice fared much better than his seership duties. He secured his medical reputation by curing a child of severe "croup" after traditional physicians had, in despair, given up. Croup was "the common term for every affection of the windpipe," stridor that produced a highpitched crowing sound on exhalation. Porter (1826) notes that antiphlogistics (anti-inflammatories) were used by all physicians of the period, as were opium (Papaver somniferum) and Atropa belladonna and D. stramonium, both of which contain hallucinogenic anticholinergic alkaloids (Hartshorne, 1855).

Operating his laboratory, Walters could isolate the active anticholinergic component of the Datura plant as an extract or a tincture. He would know the appropriate doses to treat: respiratory diseases such as asthma, cough-variant asthma, and to relieve pain from sciatica, menstruation, and cancer (Benich \& Carek, 2011). Datura was well known, and "Indeed, so closely does it resemble belladonna, that even, in the intoxication which it produces, the same follies are committed." The effects of this plant are well-known in 
some parts of Europe, and the plant was vulgarly called "Herbe aux Sorciers" (Thomson, 1832) and was "commonly connected with witchcraft, death, and horror" (Folkard, 1884). Walters undoubtedly used anticholinergics such as A. belladonna, D. stramonium, and Hyoscyamus niger as treatments and knew of their use as visionary substances. He may have also known the antidepressant properties of anticholinergic-facilitated experience and used these medicines to treat melancholy (Drevets, Zarate, \& Furey, 2013). Further suggesting that Walters prescribed psychoactives is a statement in the following report in the Geneva (NY) Times, "In the olden days, roots, herbs and vegetables were considered highly essential as medicine for nervous disorders by a number of physicians. Among the early physicians to use these ingredients in his prescriptions for nervous disorders was Dr. Luman Walters, a noted physician and surgeon who practiced in the village of Gorham over a half-century ago" (Anon., 1929).

Walters would have brought from Europe the medical and occult books from which he taught and perhaps loaned to the Smiths. Anyone with access to The Magus, such as Walters and the Smiths did, would read recipes describing hallucinogenic anticholinergics, or "herbs of the spirits" that could be smoked, used orally, dermally, or intravaginally. Ceremonial magicians in both Europe and America used visionary substances. Dale Pendell notes that included in John Porta's book Natural Magick, published in 1558, " a number of recipes both for sleeping potions and madness potions, using stramonium (Datura), belladonna, and henbane. Natural Magick was an immediate best-seller" (Pendell, 2005 , p. 244). Weirus includes "nightshade" in his visionary formula. Although nightshade can be a generic term for members of the Solanaceae family, including the Solanum genus of food plants such as tomato, potato, and eggplant, it could also be a term for highly toxic Bittersweet (Solanum dulcamara), or woody nightshade, with purple and yellow flowers and red ovoid berries (Evens \& Stellpflug, 2012).

\section{Frederick G. Williams, Apothecary}

One early convert to Mormonism living in Kirtland was a second-generation German immigrant named Frederick G. Williams. Born in October 1787, Williams took up the practice of medicine around 1816 after the death of his sister-in-law during childbirth. Williams gravitated towards Thomsonianism medicine and was frequently called an "herbal" or "vegetable" doctor. However, Williams (2012) did not limit his practice to herbal medicine; his skill set included setting fractured bones, suturing wounds, and treating burns, cholera, venereal disease, and delivering newborns (Williams, 2012, pp. 10, 15, 159, 162, 167). If Williams followed Samuel Thomson's (1841) Materia Medica, which was in its 13th edition, he would have given enemas to assist with childbirth (p. 698), and if needed, given a tea consisting of raspberry leaves and "No. 2," the later signifying the class of medicinal stimulants found in London and Edinburgh Dispensatories (p. 115). Since 1822, ergot of rye was thought "to be the most efficacious remedy in cases of protracted labor and excessive hemorrhage" and by 1838 , was "was available in every dispensary in London" (Bauer, 1838, p.479).
Favoring herbs himself, Smith had great sympathy for this branch of medical practice. Soon after his induction into the religion, Smith appointed Williams to the office of Second Counselor to the Prophet, Smith's scribe, and printer for church publications. As a physician, Williams was "universally known through this country as an eminent and skillful man" saving Samuel Smith's wife in childbearing and reviving the newborn child (Williams, 1972). Fellow physicians living in Nauvoo used ergot in the obstetrical practices and we have no reason to believe that Williams' skills were any different.

\section{Indian Mission}

One aspect of Williams' involvement in early Mormonism was his mission journey to proselytize to the Native Americans from late 1830-1831. Joseph Smith revealed to Oliver Cowdery and three other Elders they were to commence their missionary efforts to the Lamanite, as Smith called Native Americans Indians (Smith, 1833, p. 68) and scout the location for a satellite "stake" (or congregation) to be organized in Missouri. During this journey, the missionaries met Williams, and he joined the group to meet with, and proselytize to, the Natives near modern Kansas City, Missouri, in a Native settlement known as Kaw Township. For a botanically centric physician, an opportunity to meet with the so-called "Lamanites" and intermingle knowledge of herb craft and mysticism with the people who had been using American plants for millennia would have been an exciting prospect. Dr. Williams' medical practice later reflects this newfound knowledge of "Indian medicine," as evidenced by multiple advertisements Williams published in the Quincy Whig from 1839 to 1842 (Williams, 2012, p. 169).

The overwhelming logistical constraints of supplying scores or hundreds of Mormons on multiple occasions with various plant medicines could have been satisfied by an experienced Thomsonian Botanical physician like Frederick G. Williams, with his herbarium. As evidence of their close fraternity, Joseph Smith named one of his children after Frederick G. Williams. Smith had a strong and previously unremarked tendency to draw physicians close to him and place them in positions of close confidence. Smith began his career as a seer with botanical physician Luman Walters as his mentor, and later made Frederick Williams one of his top two or three confidants. In the early 1830 s, Smith ordained him his counselor in the newly organized First Presidency. In the early $1840 \mathrm{~s}$, he made physician Willard Richards an apostle and his private secretary. Also, around the same time, he made physician John Cook Bennett a counselor in the First Presidency and arguably his right-hand man and closest companion in the early 1840 s.

\section{ENTHEOGENIC MATERIALS}

The availability of entheogenic material to the Smith family and their ability to process and utilize it are foundational to our thesis of an entheogenic early Mormonism. Sources of entheogens available to the Smith family and other herbalists interested in divination, visions, and spiritual ecstasies 
included D. stramonium, A. muscaria variation guessowii, Psilocybe ovoideocystidiata, and C. purpurea. Moreover, with established trade networks extending into southwestern Texas, Smith Joseph Smith potentially had access to two additional entheogens, Lophophora williamsii and Incilius alvarius.

\section{D. stramonium and $\boldsymbol{H}$. niger}

Two prominent members of the Solanaceae plant family were available in the areas the Smith family domiciled, D. stramonium (Jimson weed or Jamestown weed) and $H$. niger (Black henbane). The Drug Enforcement Administration (2013) reports datura plants growing wild, as ornamentals, and in herbal gardens throughout much of the United States from the northeastern states to Texas; and the USDA plant database shows both D. stramonium and $H$. niger growing in extensive areas across the entire Northeastern states and other areas in the country.

Both plants contain the tropane alkaloid deliriants atropine, hyoscyamine, and scopolamine and are among the oldest medicines known to humankind (Sweta \& Lakshmi, 2015); physicians used them since antiquity as effective medicinals in Eurasia (Alizadeh, Moshiri, Alizadeh, \& Balali-Mood, 2014), and early post-colonial America (Ashe, 1808; Coxe, 1827, pp. 209-210). Datura, for example, was used for its analgesic, antispasmodic, anti-inflammatory, and antihelmintic properties (Soni, Siddiqui, Dwivedi, \& Soni, 2012). Antithetically, 19th-century clinicians reported successfully treating a case of a chronic delusional state with a 10-day course of carefully prescribed D. stramonium (Sigmond, 1849).

Magico-religious practitioners also used hyoscyamine and scopolamine since antiquity (Muller, 1998), primarily to facilitate visions and ecstasies during divinatory and shamanic healing ceremonies, religious rituals, and witchcraft (Busia \& Heckels, 2006; Keller \& Kane, 1967). Anticholinergics were also used as an anesthetic by the Greek physician, Pediacus Dioscorides (c. 40 - 90 AD), and noted by the Roman encyclopedist, Aulus Celcus (c. $25 \mathrm{BC}-$ c. 50 AD). In the earliest attempts at general anesthesia, wine extractions of the bark of the root of mandrake, and the seeds of opium and henbane were used to cause "dead sleep" so the patient "not apprehend the pain" of surgery (Carter, 1996).

The properties of datura were also well-known among colonials living in 18th-century Boston (Meyers, 2011, p. 40). During the 1676 rebellion by Virginia settlers, "hungry [British] soldiers consumed the plant and then hallucinated for eleven days" (p. 58). This same symptomology will return in 1830-1831 Kirtland.

\section{P. ovoideocystidiata}

P. ovoideocystidiata (Figure 15) mushroom ranges from Rhode Island to Kentucky and is especially common in the Ohio River valley (Guzmán, Gaines, \& Ramírez-Guillén, 2007). These mushrooms are usually harvested from April to mid-June but sometimes persist into late September or early November and have a farinaceous or flour-like taste, possibly making ground-up mushroom concealable in bread.

Psilocybin-containing mushrooms have different pharmacology than A. muscaria and historically are a major

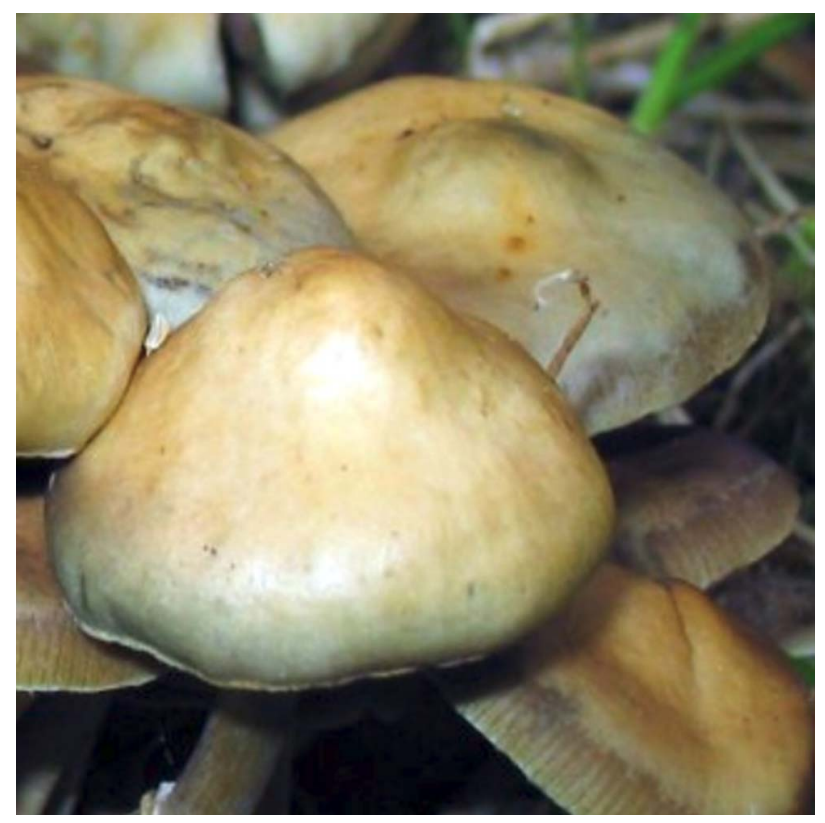

Figure 15. P. ovoideocystidiata (Shutterstock photo)

entheogen in cultures worldwide. When ingested, psilocybin content of these mushrooms is dephosphorylated into the psychoactive compound psilocin, explaining why these fungi "have been exploited for their psychotropic effects since prehistoric times" (Guzman, 2009). Psilocybe species mushrooms are best known for their entheogenic use in pre-Columbian Mexico, where they were used at least the last 2,000 years. Psilocybe mushroom use extends back to 6000 BP in Europe and to 7000 BP in Africa (Ruiz, Piper, \& Ruck, 2011).

\section{Amanita muscaria}

A. muscaria var. guessowii mushrooms, such as the one shown growing near Kirtland, Ohio in Figure 16, are widely distributed in the woodlands and forests of Northeastern America, where it is recognizable by its yellow to yelloworange cap with remnants of the universal veil forming white scales and a skirt about its stem (Ostry, Anderson, \& O'Brien, 2010). It fruits in enormous quantities, often attaining dinner-plate size, and can be found growing in a circle or "fairy ring" around its host tree. The fairy ring can be striking in appearance, especially as the mushroom matures and takes on a golden color, enhanced by the early morning or evening light (Heinrich, 2002, plate 36). The cap contains ibotenic acid and muscimol, with the more hallucinogenic and less toxic muscimol content increasing as the mushroom dries.

A. muscaria may be the oldest entheogen known with some believing its use began after the "last Ice Age in the northern Eurasian forest belt [and] spread north following the retreating polar ice cap, approximately 11,000 B.P." (HajicekDobberstein, 1995. p. 100) and used as an entheogen by Siberian shaman for millennia (Lee, Dukan, \& Milne, 2018). Further, Indo-European speaking groups developed "a vocabulary pertaining to its shamanic use" followed centuries later by the "priests of the Vedic culture [who] sang 


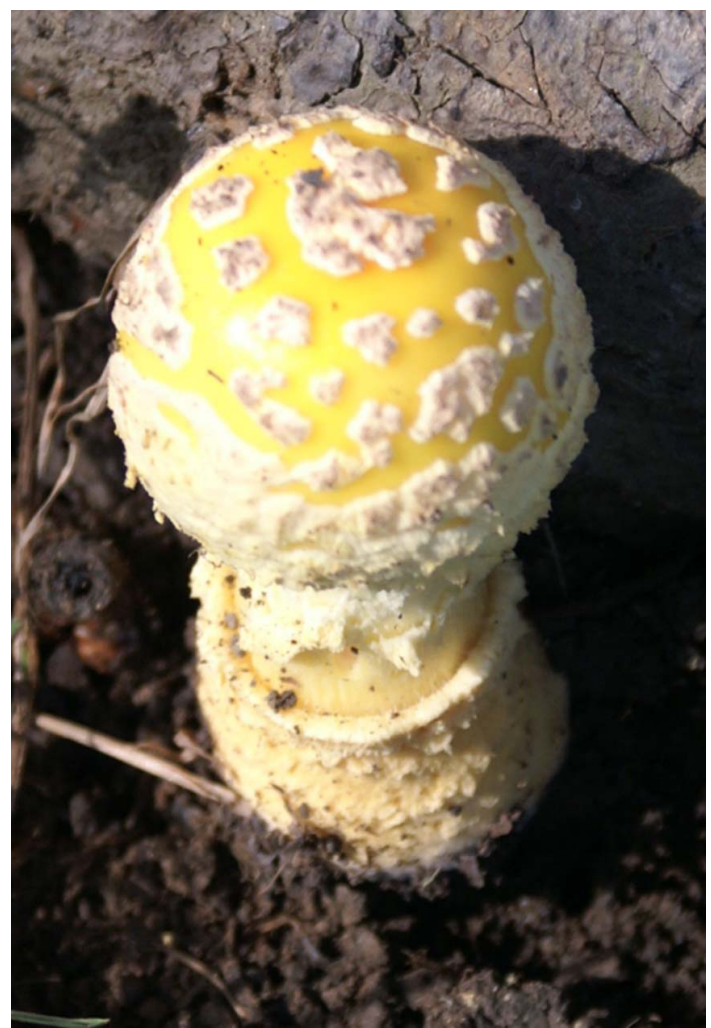

Figure 16. A. muscaria var. guessowii found just outside Kirtland, Ohio (photo by Robert Beckstead, 2007)

hymns in praise of Soma the god, the sacred plant and the sacred drink pressed from the plant" (Ibid). It appears from the 2nd to the 9th-century CE among "Buddhist adepts ... [who] may have been ingesting this mushroom" as an entheogen (Ibid). A. muscaria use appears in alchemy, Christianity, and among free and adept masons; we argue that it appears in the dreams and visions of the Joseph Smith family.

\section{C. purpurea (ergot and mushroom)}

The physicians Luman Walters, Frederic G. Williams, and John C. Bennett (see below) may have provided Joseph Smith with visionary ergot. In Figure 17, soft white sphacelia (tissue) is producing sugary or honey-tasting honeydew (Shelley, 1995). The darkly colored sclerotium in Figure 18, when mature, drops to the ground. When there is moisture, ergot on the ground germinates, forming mushroom-like fruiting bodies (stromas) with stipes and heads of various colors in Figure 19. The non-water-soluble ergopeptine alkaloids "were the agents responsible for the recurring plagues of ergotism known throughout European history" (Webster, Perrine, \& Ruck, 2000, p. 8). The same alkaloids were used by physicians since the 16th century to stimulate uterine contraction to hasten childbirth, to stop post-partum hemorrhage, or to induce abortion (Scarborough, 1971). Use of ergot for these purposes included 1840s Nauvoo, Illinois where it was available to Mormon physicians.

William Shelley (1995) argues that ergot use as an entheogen can be "traced through the Greco-Roman World, through the worship of Mithra and the Hebrew Scriptures into the activities of the early Christians and from there to the 'hidden tradition' of alchemy"' (Marshall, 1999).

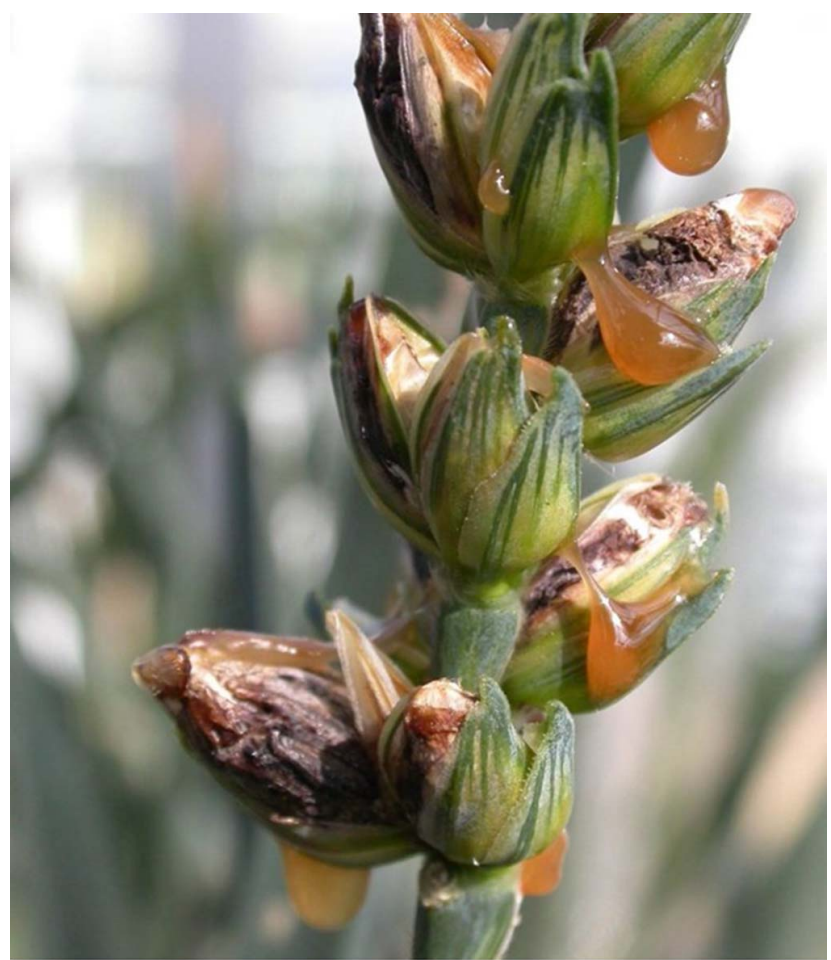

Figure 17. Sweet Honeydew stage of ergot on wheat development (photo by Crop Production Magazine, 2018)

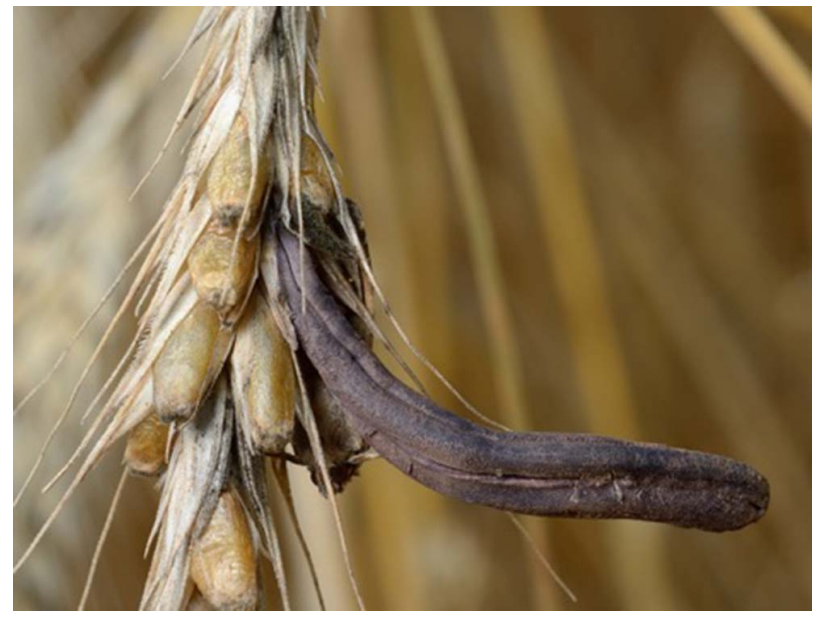

Figure 18. Ergot (C. purpurea) sclerotium on rye (photo by Dominique Jacquin. Shutterstock)

Water-soluble psychoactive alkaloids from C. purpurea (ergot) include ergonovine and methylergonovine (Webster et al., 2000, p. 2). These alkaloids are believed to constitute the kykeon elixir of the greater Greek Eleusinian mysteries (Wasson et al., 2008). Peter Webster argues that "Greek priests could easily have harvested enough ergot [0.5 kg] from the nearby barley fields [to serve] 1000 Eleusis participants" (Webster et al., 2000, p. 8).

"Hierophantic priests might well have discovered how to achieve partial hydrolysis of the most toxic alkaloids of $C$. purpurea, resulting in an extract of ergot containing a blend of psychedelic[s] ... eliminat[ing] the toxic ergopeptine alkaloids, converting them to psychoactive ergine and isoergine ... closely similar to the Aztec's ololiuqui" 


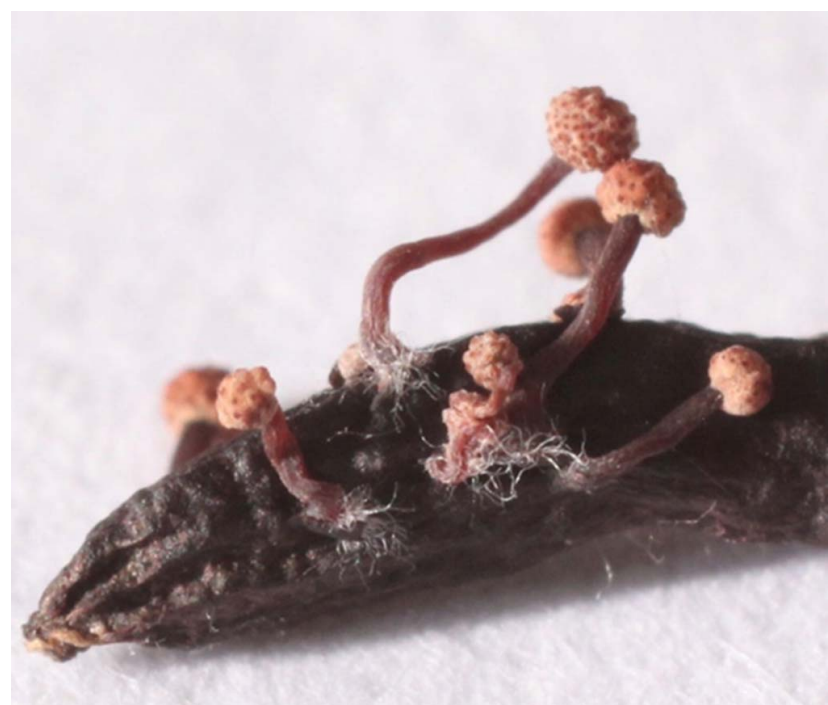

Figure 19. Stromata germinating on a sclerotium of C. purpurea (photo by KnarkKorven, 2011)

(Ibid, p. 7), LSD, or psilocybin (Wasson, Kramrish, Ott, \& Ruck, 1986).

The life cycle of ergot lends itself to allegory in esoteric Judeo-Christian as it does in spiritual alchemy and masonry. For instance, the manna which Moses said came from heaven tastes "like wafers [made] with honey" (Exodus 16:14, "KJV"), a description consistent with ergot's honeydew stage. While undetected ergot infects bread and causes disease, water-soluble alkaloids can be added to bread, making it an entheogenic Hebrew sacrament. Consistent with entheogenic use of ergot, Moses tells the tribes of Israel that manna is "the bread which the Lord hath given you to eat" (Exodus 16:15), a theme echoed in the Christian era when Jesus says here is the "bread of life" (John 6:30, "KJV").

Figure 20 shows frame from the $c a$. 1200 Great Canterbury Salter, in Canterbury, England, titled "God Creates Plants" showing God with four mushroom-appearing figures below him; all five figures have uplifted hands seeming to mirror each other. This medieval salter reveals esoteric Christianity's fascination with entheogenic mushrooms. In this figure, God appears to wear an A. muscaria cap showing its gill side down, while the left-most figure appears to be a stylized Psilocybe mushroom and the farright figure appears to represent the stromata of an ergot fungus sclerotium. The dark, purplish sclerotium in Figure 18 that has replaced a grain of rye will remain dormant for an extended time if harvested, or fall to the ground. The grounded sclerotium will eventually be moistened by rain or irrigation and produce stroma resembling tiny mushrooms in Figure 19, while Figure 21 is an enlargement of a stroma showing its yellowish-red stippled head comparable to the head of the rightmost mushroom figure in the salter frame.

A Mason and early Mormon convert, John C. Bennett, was a practicing physician and obstetrician. There is circumstantial evidence that Bennett, accused of administering "medicine" to induce abortion, was familiar with the medical uses of ergot (Hedges \& Smith, 2010). Luman Walters or Frederick G. Williams likely had the education and practical training to cultivate, harvest, and prepare the psychoactive materials associated with ergot for the Kirtland temple.

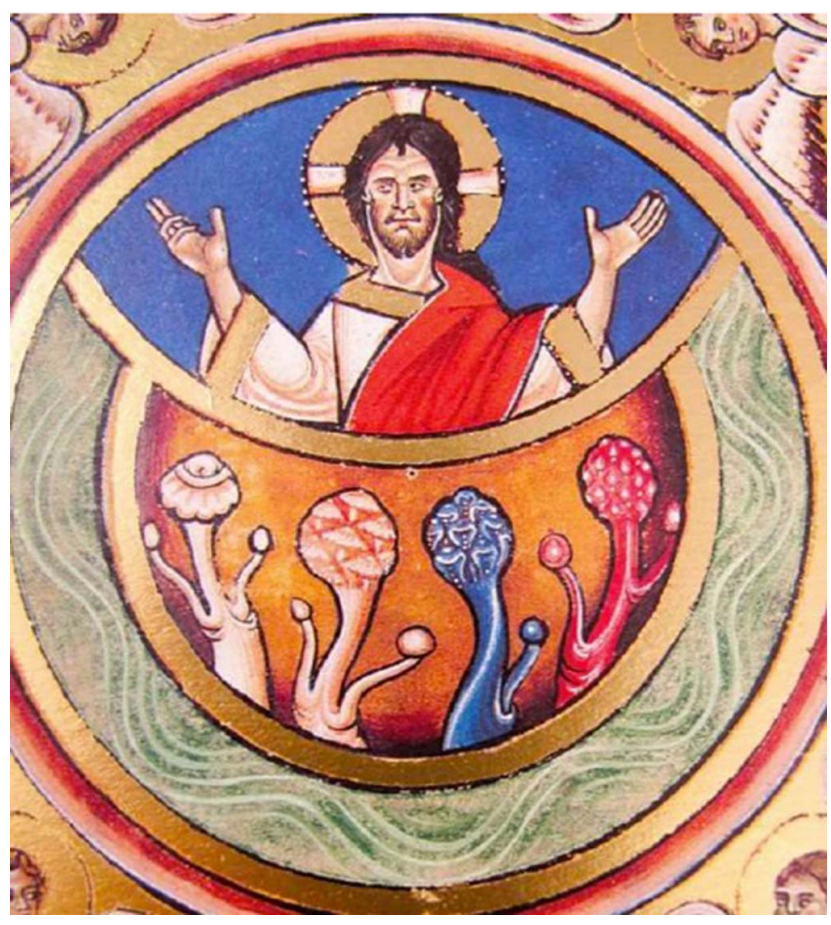

Figure 20. God Creates Plants, ca. 1200. Public domain

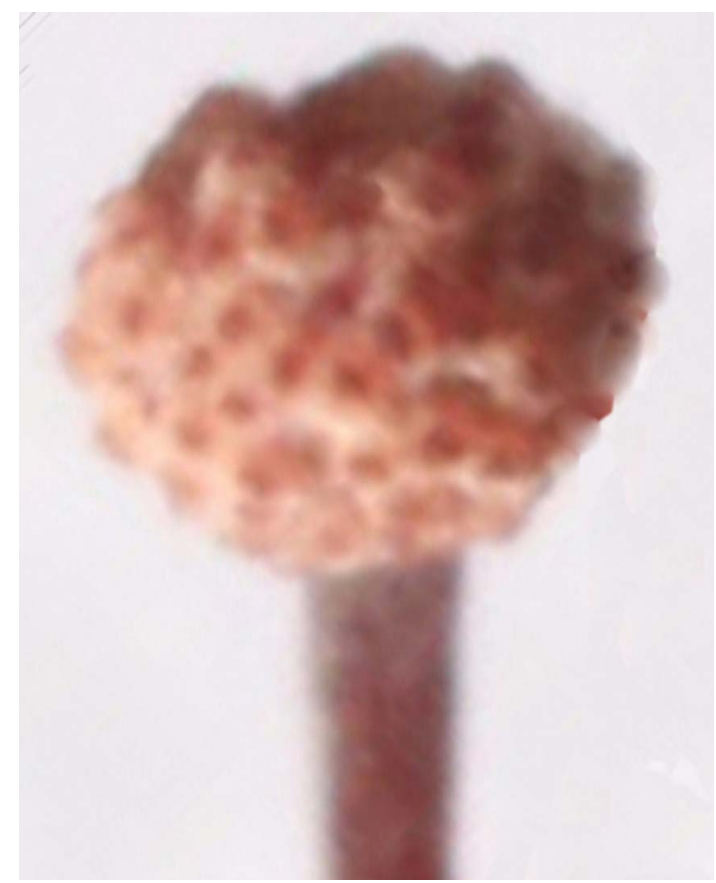

Figure 21. Enlarged ergot stroma (adapted from Figure 19)

Bennett would have been qualified to safely prepare visionary ergot as a ceremonial entheogen in the Nauvoo temple.

\section{L. williamsii (peyote)}

During the period of Indian Removal beginning in 1830, Native Americans living east of the Mississippi River passed through Nauvoo on their way to their seasonal hunting grounds. Potawatomi delegations, also often including members of the Fox and Sauk nations, visited Joseph 
Smith between April 18 and August 28 of 1843 (discussed below). The purpose of these negotiations is not altogether clear to historians. However, as we will see, the negotiations probably involved Joseph Smith giving valuable and sacred property to the Potawatomi without apparent gain to Smith in return. We suggest that Joseph Smith may have negotiated with Native Americans for the delivery of peyote to Nauvoo for the Nauvoo temple endowment.

Peyote (L. williamsii) in Figure 22 grows along the Mexican-Texas border and has been used in Native American magico-religious ceremonies for millennia (Bruhn, De Smet, El-Seedi, \& Beck, 2002). "Indians regard the [peyote] as a panacea in medicine, a source of inspiration. Moreover, [it is] the key which opens to him all the glories of another world" (Stewart, 1974, 1987). In aboriginal time, the peyote cult was among the Uto-Aztecan tribes (Slotkin, 1955, p. 203), and perhaps even earlier "in the Mesoamerican and Greater Southwest cultural superareas" (Ibid, p. 204), and among "tribes adjacent to those of the United States: Pima, Opata, Jumano, Lagunero, and Coahuilteco" (Ibid, pp. 206-207). The diffusion of peyotism northeastward occurred in stages beginning to the "Old Peyote Complex" of Mexico before the Spaniards arrived in the 16th century, eventually culminating in the Plains Indian Peyote Religion in the late 19th century (Slotkin, 1955, p. 28; Troike, 1962). The map in Figure 23 shows the location of the peyote beds (dark gray) and the Indian tribes (light gray) who were practicing peyotism before 1800 (Slotkin, 1955, p. 207). When Joseph Smith sent Lyman Wight to Texas to establish Mormon colonies, he would have been in contact with both the source of peyote and Native Americans expert in its use.

After the Spaniards took control of what is now Mexico in 1571, peyote cults were suppressed by priests of the Catholic Inquisition, who nearly eradicated peyote rituals. An Inquisition document of 1620 outlines Catholic opposition to the ancient Amerindian religion and its peyote sacrament:

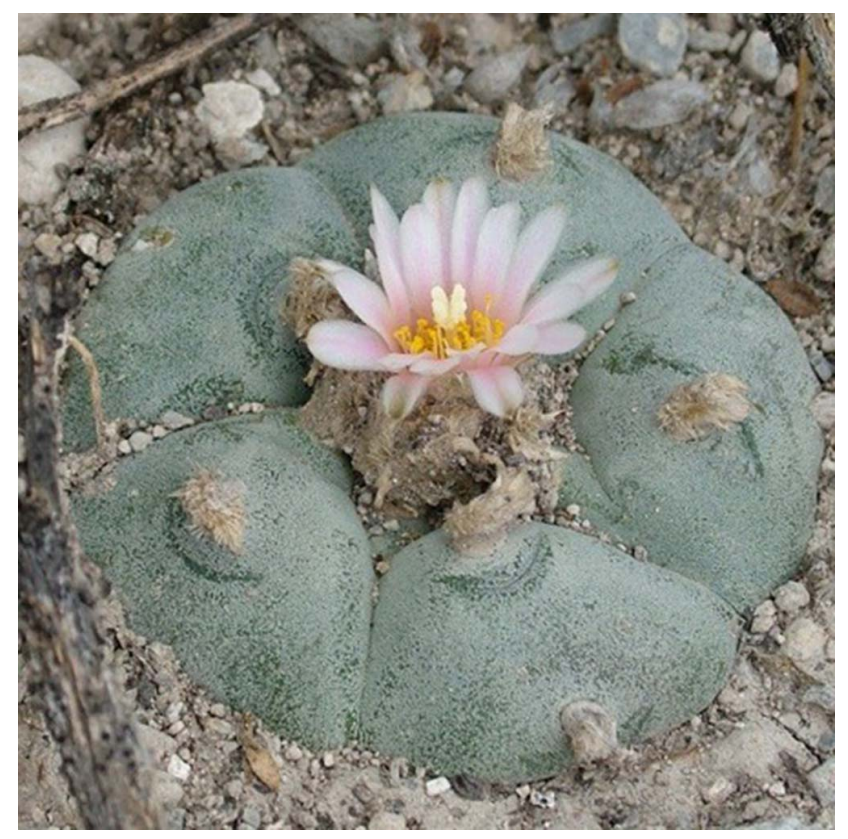

Figure 22. Peyote cactus (L. williamsii) (Shutterstock photo)

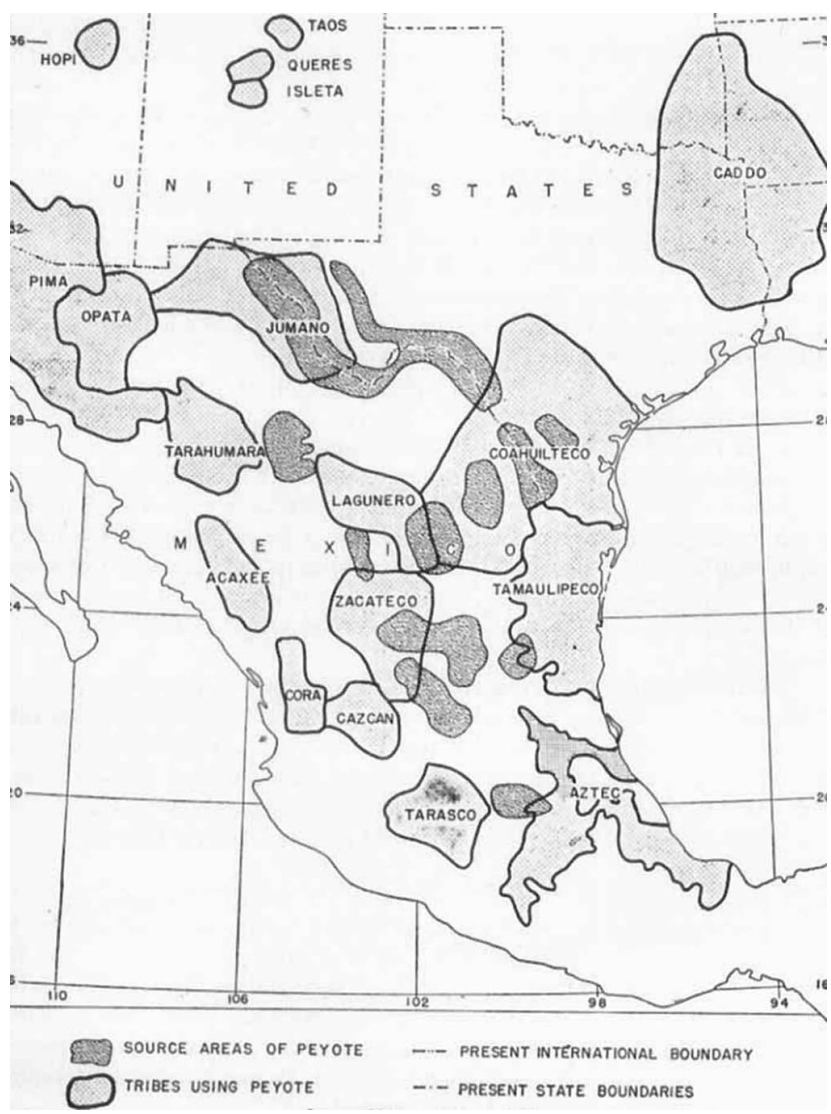

Figure 23. Tribal distribution of peyotism before 1800. Map by Allen K. Philbrick (Slotkin, 1955, p. 107)

“... peyote has been introduced into these provinces for the purposes of detecting thefts, of divining other happenings and of foretelling future events, it is an act of superstition, condemned-as opposed to the purity and integrity of our Holy Catholic faith. The fantasies suggest the intervention of the Devil, the real authority of this vice" (Rudgley, 1993, p. 75).

Peyote cult recovery first took place among the Huichol (discussed below) and Tarahumara tribes. Peyote use among Mescaleros and Lipan Apache likely had its origin in the late 18th century with "the Apache making one ritual complex from features selected from the totality of the Mexican and Spanish religious and ceremonial life they knew" (Stewart, 1948, pp. 35-36). Also, Åke Hultkrantz (1997, p. 31) argued there are "reasons to assume that Mexican tribal Peyote ritualism constituted the transition to the Plains Peyote rite, and thereby to the modern Peyote religion" with intermediates being the Comanche, Kiowa, and Kiowa Apache. Further, there is evidence of peyote use by Lipan Apache in the 1770s. It would be naive to believe that Plains Indians shaman, medicine men, or doctors would not have been interested in peyote long before the establishment of Peyote religion.

Why would Joseph Smith be interested in peyote that requires an overland journey of 1,300 miles through Missouri, Kansas, Oklahoma, and Indian Territory before arriving in the peyote fields? We suggest that Smith heard of "aspects of peyotism" and its visionary properties as information made its way east, until in 1835, there were "European [peyote] cactus fanciers" (Slotkin, 1955, p. 208). 
Typifying Native American's feelings about peyote, Comanchero war chief Quanah Parker once spoke of the advantage peyote offered Native American religion over those in the United States:

The white man goes into his church house and talks about Jesus, but the Indian goes into his tipi and talks to Jesus" ... [and the Indians received] "their inspiration from the Great Father, while the white man [received] his through the book they have." (Hagan, 1995, p. 56)

Joseph Smith, who had promised converts visions of God, would have been naturally interested in the ceremonial use of peyote for Mormon rituals. Below we discuss evidence he sought to obtain peyote.

\section{Incilius alvarius (Sonoran Desert toad)}

One of the most dramatic religious experiences found in the "Tree of Life" dream accounts reported by Joseph Sr. and recorded in The Book of Mormon by Joseph Jr. may be

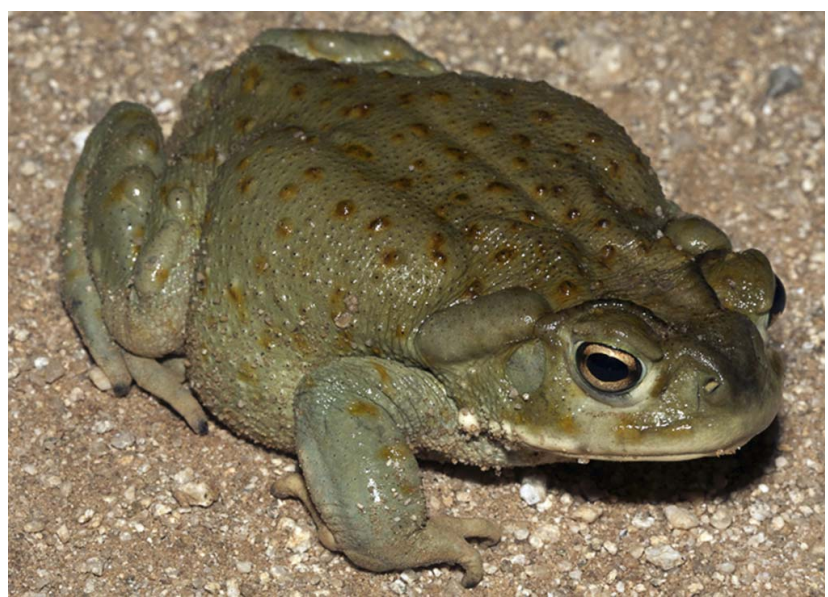

Figure 24. Sonoran Desert toad (I. alvarius) (photo by Todd Pierson, 2011). Creative Commons

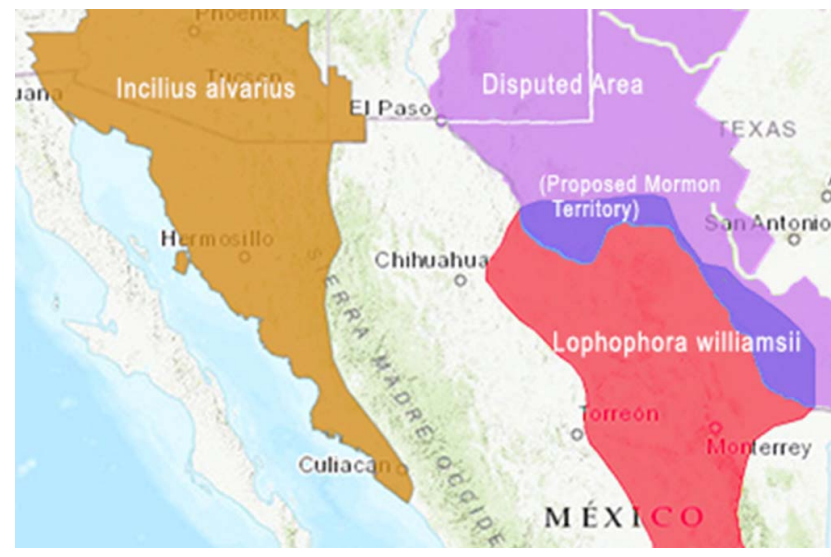

Figure 25. Distribution of I. alvarius in brown (Terry, 2017), L. williamsii in red (Hammerson \& Santos-Barrera, 2004), and the proposed Mormon territory in purple (see text). The area where $L$. williamsii overlaped with the proposed Mormon territory is in blue.

Distribution of I alvarius and L. williamsii adapted from the University of Texas Libraries at Austin facilitated by smoking parotid gland secretions of the Sonoran Desert toad (I. alvarius) shown in Figure 24 and found in the same general area as peyote (see Figures 23 and 25 below).

According to Lyttle, Goldstein, and Gartz (1996), "Bufo toad (and related genera) has held a place in humanity's archaic consciousness since time immemorial. The earliest representations of Bufo toads (and toads generally) go back thousands of years. The appearance of toad-based artifacts is prehistoric were portrayed in ancient pictographs, paintings, and sculpture" (p. 268). Secretions harvested from the parotid glands of $I$. alvarius are rich in highly entheogenic 5-MeODMT (Barsuglia et al. 2018; Griffiths, 2018). Evidence suggests that 5-MeO-DMT, harvested from I. alvarious, was an entheogen used by the Olmec, Mayan and especially the Aztec civilizations where "Aztec icons focus in great detail on the Bufo toad's parotid glands, which contain substances that may be trance inducing" (Lyttle et al., 1996, p. 269). The I. alvarius in Figure 24 bears a striking resemblance to preColumbian stone toad effigies such as the toad effigy with the Mayan Sun-God carved on its back from Northern Guatemala or Southeastern Mexico, in Figure 26, and the stone pipe toad effigy from the Ohio Hopewell Culture in Figure 27.

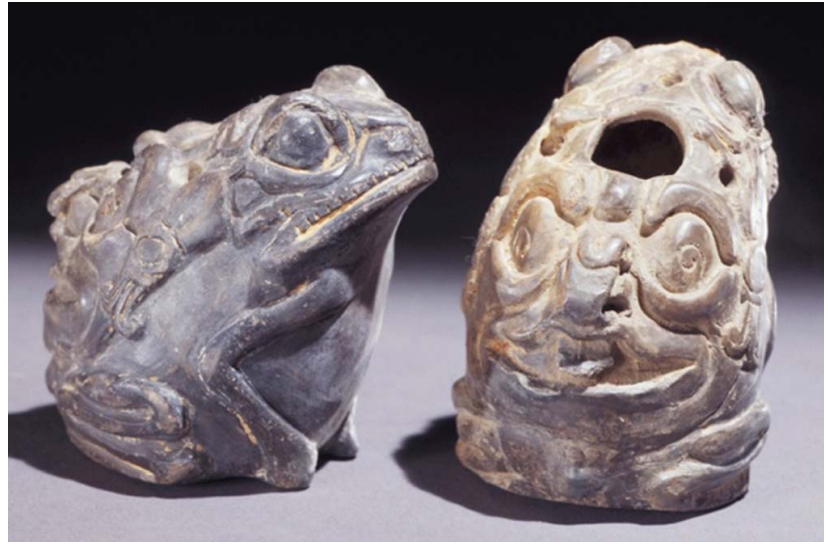

Figure 26. Toad-shaped Effigy container carrying Sun-God mask from Guatemala or Mexico (photo from Art of the Ancient Americas, Los Angeles County Museum of Art. Public Domain)

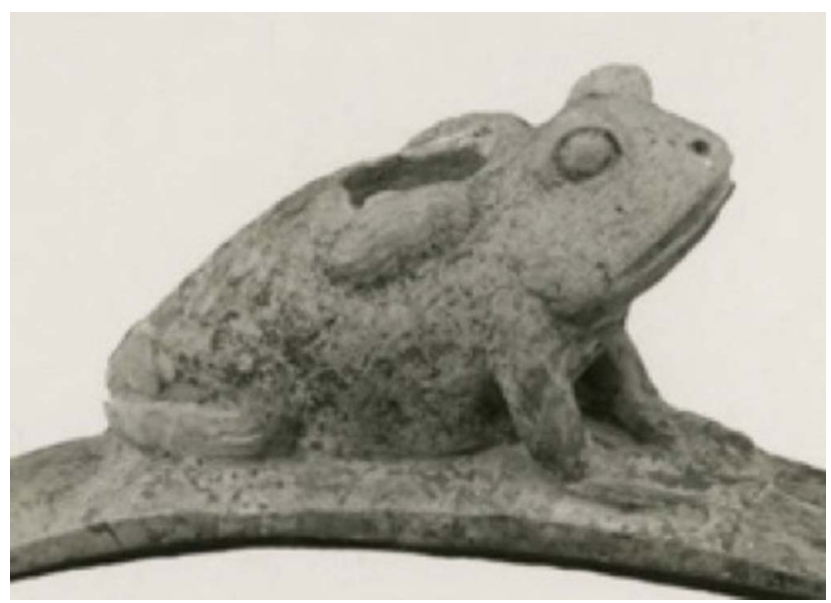

Figure 27. Stone toad of Hopewell culture origin (100 BC-400 AD). Ohio History Connection Archaeology Photograph Collection 
Early critics of Mormonism linked magical toads with Joseph Smith. For instance, a neighbor of the Smiths, Willard Chase, reported that in 1827, Joseph Smith's father related the following story:

Some years ago a spirit had appeared to Joseph, his son, in a vision, and informed him that in a certain place there was a record on plates of gold ... [and that] he must repair to the place where was deposited this manuscript... [Joseph Smith repaired to the place] opened the box, and in it saw the book, and ... something like a toad (Howe, 1834, p. 242)

The subsequent transformation of the toad described by Chase strongly suggests an entheogenic source for this vision.

Further, in 1830, the year Joseph Smith finished his "translation" of the "plates of gold," his occult mentor, Luman Walters reportedly possessed a stuffed toad (Quinn, 1998, p. 117), a common familiar of a conjurer (Ermacora, 2017). Walters, who traveled in Europe, would have known the toad's magical and possibly hallucinogenic properties. According to Lyttle et al. (1996), the more "purely psychedelic applications of the Bufo toad had to do with the so-called toad stone, supposedly found in the head [parotid gland?] of the Bufo toad ... In 1644 [France], Boetious de Boot, in his Parfait Joallier [Perfect Jeweler], described 'the toad stone' alleged 'to exist in the toads head ... another sure talisman for obtaining perfect Earthly happiness."

The twice mentioned "toad" during the production of The Book of Mormon suggests the remote possibility that Smith employed a toad entheogen in its writing. Further, the happiness mentioned by Boetious de Boot is a significant sequela of many early Mormon visions discussed below. For Joseph Smith to have used toad 5-MeO-DMT, it would have had to been smoked or snuffed. Further, I. alvarius entheogen would have had to be transported from Southwest Texas (Figure 25) along existing Indian trade routes into the American Northeast (Tanner, 1996, see map by Sanderson Associates). Peyote, found in Texas (Figure 25), retains its potency ( $2 \%$ mescaline) over thousands of years (Terry, Steelman, Guilderson, Dering, \& Rowe, 2006), while5-MeO-DMT retains its potency over a much shorter period. Although no literature indicated how long and at what temperatures, 5-MeO-DMT remains active, if it is like is cousin, N, N-dimethyltryptamine, its salts retain their potency significantly longer than when kept in solution. Presuming this entheogen remained active between harvesting, arrival in the Midwest, and use, a stuffed toad with 5-MeO-DMT could easily supply the needs of a magician or seer for a prolonged period or a small congregation of believers for a year. Further 5-MeO-DMT would be an attractive entheogen for Joseph Smith due to its immediate and profound antidepressant properties (Davis, So, Lancelotta, Barsuglia, \& Griffiths, 2018).

Had Joseph Smith known the features of entheogenic toad venom, he would have undoubtedly arranged for its procurement and transport to Nauvoo in the 1840s. Further, in 1844 , Joseph Smith instructed fellow Mormons to settle the region surrounding the Rio Grande River. One follower, Lyman Wight (referenced below) went to Midwestern Texas to form the Mormon colony of Zodiac (Langford \& Bandera, 2003), a site within easy traveling distance to both the peyote beds and the Sonoran Deseret Toad catchment area. Figure 25 also shows the area where the distribution of $L$. williamsii and Native American expertise in peyote sacraments and medicine overlapped with the proposed Mormon territory.

\section{SHAMANIC TRANSFORMATION}

We have discussed mentors for Joseph Smith, which we believe knew entheogens and employed them in his mentoring. Overwhelming childhood trauma suffered by Joseph Smith facilitated his formation as a shaman prophet of a successful new religion, enabling the use of entheogens to their maximum religious potential.

\section{Unimaginable childhood trauma}

Groesbeck (1990, 2004, 2005), a Jungian trained psychiatrist, has argued that the shamanic-healer archetype aptly describes Joseph Smith's personality structure. Groesbeck, who studied with a Huichol shaman, agreed with Mircea Eliade (1964) that the shaman's role and function depended on their techniques of facilitating ecstasy. According to Eliade, a shamanic healer's abilities in ecstasy or trance, to enter "into contact with divine or semidivine beings" (p. 84) and to "consort with the dead with impunity" (p. 214), generally resulted from severe trauma during early life. This shamanic complex and its archetypal pattern result from a severe illness early in life and strenuous ordeals (Groesbeck, 1975, 1989). Joseph endured such an ordeal at age 7 when stricken with life- and limb-threatening osteomyelitis secondary to typhoid fever (Adams, 2013; Morain, 1998, 2013; Wirthlin, 1981). In a horrific and prolonged ordeal, the young Joseph Smith (1833) suffered multiple exquisitely painful surgical procedures without the benefit of anesthesia or sedation. One might get a sense of what this 7-year-old boy must have endured in a revealing revelation:

I [God] command you [to] repent, lest I smite you ... and your sufferings be sore. How sore you know not! How exquisite you know not! Yea, how hard to bear you know not! (Smith, 1833, p. 23)

The appalling nature of young Joseph's surgeries, documented by physician LeRoy Wirthlin, is incomprehensible except to those who have experienced them (Wirthlin, 1981). William Morain, a surgeon with a Mormon background, describes how the terror of such painful surgical assaults creates dissociative injuries within a child's developing brain that become "an integral part of the psyche that can permeate all corners of [his] mind forever" (Morain, 2013). However, severe childhood trauma does not explain his ability to facilitate en masse visionary experience; and does not explain the anticholinergic symptoms associated with his own early visions and many early convert visions reported to have occurred between 1830 and 1831 as discussed below.

\section{JOSEPH SMITH JR.'S VISIONS}

Joseph Smith Jr. had visionary experiences in his spiritual quests that display several specific features. Analysis of 
these accounts and the features of his experiences provide data to support the hypothesis he deliberately employed entheogenic substances.

\section{0: The first vision}

At 14 (Smith, 1838) or 15 years of age (Smith, 1832), Joseph Smith Jr. embarked on a spiritual quest. Like the alchemical "philosophers" before him, one object of his quest was "wisdom" (Smith, 1838, 1843). Joseph Smith's later revelation "the Word of Wisdom" reflects the view that taking the proper things into one's body - avoiding addictants and using "every herb in the season thereof" would enable the seeker to "find wisdom and great treasures of knowledge, even hidden treasures" (D\&C 89). Before he went into the grove in 1820 or 1821 to obtain wisdom, already three powerful precedents directed Joseph to seek wisdom through what he ate. First, he had a prototype for his quest in the story of Adam and Eve, who acquired wisdom by what they ate (Genesis 3:6, 22, "KJV"). Next, the search for wisdom had also been modeled for him by the Christian alchemists and Freemasons, who sought wisdom through the philosopher's stone, the Bible's "white stone," and by partaking of the elixir, the "hidden manna" of the Book of Revelation, which also promised that "to him that overcometh" the gift to "eat of the tree of life" (Revelation 2:7, 17, "KJV"). Also, finally, the quest for wisdom was more immediately modeled for the young Joseph by the elder Joseph, his father, who had been instructed through prophetic dreams how he could gain wisdom. Here again, the model was that one could acquire wisdom by what one ate.

Joseph Smith's spiritual quest is a continuation of his father's - a quest for Christ's "primitive church" for temporal and spiritual salvation, and wisdom. Joseph Jr. reported that a quest for "wisdom" was his motivation for going to a grove of trees where, at the age of 15 , he experienced his first vision (Smith, 1839-1841, pp. 2-3). In what Lucy Mack Smith similarly called Joseph Smith Sr.'s "first vision," Joseph Sr. began a quest for wisdom and forgiveness of sins by journeying into a fallen wood. He was told, "eat," of certain edible materials found on a fallen tree, and informed, "[this] will make you wise, and give unto you wisdom and understanding" (Smith, L. M., 1853, p. 57). It would be remarkable if the younger Joseph's quest for "wisdom" were not informed by the visions of his father. Joseph Jr. should, therefore, have expected that to obtain wisdom, he also would need to "eat" something provided by God. However, where would he acquire the necessary entheogenic foods? Here again, his father's vision showed the way.

Joseph Jr. sought his visionary experience in the clearing in "early spring" (Smith, 1839-1841, p. 3), the precise time when plants would be sprouting and entheogenic mushrooms could begin to be harvested amid the dead timber. Joseph, a firm believer in providence, saw divine purposes in nature's provision of various herbs and perceived God's "hand in all things," the minute details of life (D\&C 59:21; 8,9:10-11; Bradley, 2019, pp. 186-188). After seeking a physical landscape for his own "first vision" quest for wisdom that actualized the dreamscape of his father's "first vision" wisdom quest, what did Joseph intend to do when he arrived if not to follow the commandment given to his father in his vision, to obtain wisdom?

Against the backdrop of the biblical Adam and Eve story, the Masonic-biblical promises of "hidden manna," and the visionary commandment to his father to acquire wisdom by eating what God placed on the dead timber, Joseph Jr. was primed to perceive entheogenic plants and mushrooms at the culminating moment of his search for wisdom as a providence auguring that he needed to eat to obtain wisdom and of what he needed to eat to become wise.

Another potential clue to what Joseph Jr. needed to eat to gain wisdom was the biblical description of it as the "hidden manna." The original biblical manna, appearing in the story of Moses's Exodus, was described in Joseph's King James Bible ("KJV") as round edible objects found on the ground in the morning (Exodus 16:13-15). If Smith expected the "hidden manna" to take a similar form, he would have found obvious candidates all around him in the spot where he sought wisdom, growing on and hidden under the fallen trees of his father's clearing.

Early in the spring morning, Joseph Jr. knelt under a canopy of oaks, birch, and hemlock, to petition God's forgiveness of his sins. The accounts of the ensuing vision compiled by Mormon writer Eldon Watson (1983, see also Harper, 2002, 2016) reveal the problematic mentation and peripheral symptoms secondary to the onset of what Burkhart (2004) identifies as anticholinergic hallucinogen intoxication. At the onset of his theophany, Joseph (cited in Watson, 1983) reported he:

- Saw all kinds of improper pictures;

- [Was] seized upon by some power which entirely overcame [him];

- [Was blinded as] thick darkness gathered around [him];

- His tongue ... cleaved to [the] roof [of his mouth] so that [he] could not speak;

- He heard a noise behind [him] like someone walking towards [him];

- He sprang upon [his] feet and looked round but saw no person.

- [Was] ready to sink into despair and abandon [himself] to destruction, not to an imaginary ruin but to the power of some actual being from the unseen world [with such] marvelous power as I had never ... felt in any being (see also Harper, 2012).

\section{Anticholinergic toxidrome}

Had Joseph been taken to a local physician of the period during the initial phase of intoxication, the diagnosis of poisoning with a member of the Solanaceae family, such as Black Henbane (H. niger) or D. stramonium would have easily been made ("Communications", 1811; Copland, Darwall, \& Conolly, 1826, pp. 422-423; Jonasson \& Afshari, 2016; Thornton, 1811, pp. 55-61; W, 1833). Similar clinical features can also present with poisoning by the $A$. muscaria mushroom (Burkhart, 2004, p. 691; Cahill, 2003; RolstonCregler, 2017). Ibotenic acid (pantherine and agarine) and muscimol are among the active components of $A$. muscaria, substances that with powerful effects on the central nervous 
system. Although tropanic alkaloids are not present, the signs and symptoms of poisoning with the fly agaric are called "mycoatropinic," and they resemble those produced by $D$. stramonium, A. belladonna, and $H$. niger (Satora, Pach, Butryn, Hydzik, \& Balicka- lusarczyk, 2005).

The symptoms Smith experienced related to those of the anticholinergic or mycoatropinic toxidrome were: hypertension and hyperthermia, agitated hallucinations, delirium and strange mental states, slurred speech, tremors, coma, and occasionally seizures, tachycardia and dysrhythmias, dry and flushed skin - especially the face-dilated pupils, mydriasis, and blurred vision, and dry mouth. These symptoms constitute one of five basic toxidromes (Omar, \& Foxworth, 2014). Features of the anticholinergic toxidrome in Joseph's accounts of his first vision include being rendered "blind as a bat" (mydriasis, blurred vision), "mad as a hatter" (altered mental status, delusional paranoia, and hallucinations), and "dry as a bone" (dry mucous membranes), and a duration of intoxication lasting several hours or more. Paralysis associated with D. stramonium is also reported (Anon., 1811).

Young Joseph either understood the sublethal, visionary dose or was lucky, since coma and death may ensue in severe poisonings of D. stramonium (Le Garff, Delannoy, Mesli, Hédouin, \& Tournel, 2016) and A. muscaria (MikaszewskaSokolewiczi, et al., 2016). From Eldon Watson's (1983) textural harmony of Joseph Smith's first vision, we learn that just as Joseph was anticipating ego dissolution and imminent death, a "light appeared to ... gradually descending towards him" until he was "surrounded by a brilliant light" creating "a peculiar sensation throughout his whole system" and causing "his mind" to be "caught away from the natural objects with which he was surrounded; and he was enwrapped in a heavenly vision." In the vision, Joseph's profound sense of guilt was assuaged as an angel appeared (the Lord) and assured him that his sins were forgiven. Then, "when I came to myself again," Joseph explained, "I found myself lying on [my] back looking up into Heaven ... without any strength ... [but with a] mind in a state of calmness and peace, indescribable." Joseph added, "my Soul was filled with love and for many days. I could rejoice with great Joy, and the Lord was with me."

Table 1 compares the relationship between Smith's symptomatology and those of the anticholinergic syndrome. Joseph Jr.'s description of his first vision is profoundly personal and unlikely to have been manufactured due to embarrassing symptoms diagnostic of anticholinergic intoxication he later attempted to hide or contextualize. Further confirming that Joseph was in a visibly physically altered condition after his initial recovery from the visionary state, he reports that upon his reentry into his family home, his mother asked him, "What is the matter?"

Table 1. Joseph Smith's first vision and related anticholinergic symptoms

Joseph Smith's symptoms
Category 1: Onset of
Blind as a bat ... thick darkness gathered around [him]
Dry as a bone. His tongue ... cleaved to [the] roof [of
his mouth] so that [he] could not speak
Face and skin color changes- initially flushed, then pale

Anticholinergic syndrome

anticholinergic syndrome
Pupils to dilate widely, inhabitation of accommodation of the eyes

Inhibition of salivary and bronchial secretion and sweating

Face and skin color changes- initially flushed, then pale

Bradycardia and decreasing blood pressure due to blocking of muscarinic M2 receptors on the postganglionic parasympathetic neurons

Category 2: Onset of central anticholinergic syndrome

Mad as a hatter. All kinds of improper pictures

Heard a noise behind [him] like someone walking

towards $[$ him]; ... sprang upon [his] feet and looked

round but saw no person

[Was] seized upon by some power which entirely overcame [him]

Was ready to sink into despair and abandon [himself] to destruction, not to an imaginary ruin

\section{Category 3: Anticholinergic visionary ecstasies and sequelae}

Surrounded by a brilliant light

His mind [was] caught away from the natural objects

with which he was surrounded. Was enwrapped in a heavenly vision

... an angel who had appeared (the Lord) informed him that his sins were forgiven

Hallucinations

Paranoia and delusion

Facial and body contortions, feeling bound

Fear associated with ego dissolution and/or actual death

Visions and ecstasies

Hallucinations

\footnotetext{
Category 4: After effects and anticholinergic-related mood elevation

I [lay] on [my] back looking up into Heaven ... with no

Post intoxication weakness and fatigue strength

A mind in a state of calmness and peace, indescribable

Soul was filled with love and for many days. I could

rejoice with great Joy and the Lord was with me

Desire to heal others

Peak experiences or afterglow phenomenon

Sustained mood elevation

Shamanic personality (see text)
} 
(Smith, L. M., 1853, p. 133). Similar symptoms also appeared during Mormon convert visionary experience when Joseph Smith founded his Church in 1830 (referenced below).

The positive symptoms associated with Joseph's vision also suggest the known antidepressant effects of scopolamine (from D. stramonium or Black Henbane) or possibly muscimol from Amanita muscaria. Scopolamine "produces rapid and significant symptom improvement in patients with depression" (Witkin et al., 2014), similar to the afterglow phenomenon of classic entheogens (Majić, Schmidt, \& Gallinat, 2015).

A feature of Smith's "first vision" experience that cries out for explanation is its stark tangibility and experienced veridicality. He emerged from his experience of the demonic and the divine convinced of the actuality of the beings he had encountered: "But exerting all my powers to call upon God to deliver me out of the power of this enemy which had seized upon me, and at the very moment when I was ready to sink into despair and abandon myself to destruction, not to an imaginary ruin but to the power of some actual being from the unseen world who had such a marvelous power as I had never before felt in any being ... I had actually seen a light and in the midst of that light I saw two personages, and they did, in reality, speak unto me" (Smith, 1839-1841, p. 4). Smith either found himself bound by an "actual being" and then "actually saw" a light, or there were neurophysiological changes in his brain and body that facilitated their perception. Even if Smith is understood to have encountered external spiritual forces, one would have to explain what physiological changes facilitated his ability to physically engage with entities that cannot usually be seen or felt. Entheogenic D. stramonium explains how Joseph Smith perceived his engagement with spiritual forces as an actual physical encounter.

A high dose of psilocybin would have provided the mindopening, cosmological, transformative, and disintegrating/ reintegrating aspects of the experience, while $D$. stramonium would have given the experience of another reality, initially in the grips of a terrifyingly, physically real evil being. Unbeknownst to Joseph Smith, as for the mythical Adam and Eve, eating the "forbidden fruit" entailed an experience of evil in tangible form (Satan/the serpent) to obtain wisdom - that is to experience the "deepest abyss" besides "commune with God" (Smith, 1977, p. 137). Smith also acted the part of an alchemist transmuting or "transfiguring" his physical state to enable himself to find wisdom through the visionary experience of both good and evil, Satan and God.

It is also possible that Joseph Smith used P. ovoideocystidiata or another species of psilocybin-containing mushroom, although this is less likely than an anticholinergic entheogen based solely on the symptomology. We mention the possibility of $P$. ovoideocystidiata use here because this mushroom can be found from Rhode Island to Kentucky and is especially prevalent in the Ohio River Valley (Allen, Gartz, Molter, \& Sihanonth, 2009; Guzmán et al., 2007), where it grows on wood debris, especially along rivers, streams, and wet valley areas such as the Sacred Grove. The Sacred Grove hosts a great variety of fungi, besides A. muscaria due to it residing in a small valley of seasonally wet and cooler terrain. On two visits to the Sacred Grove before the conception of an entheogenic origin of Mormonism, one author (RB) found abundant mushrooms of several varieties, including one

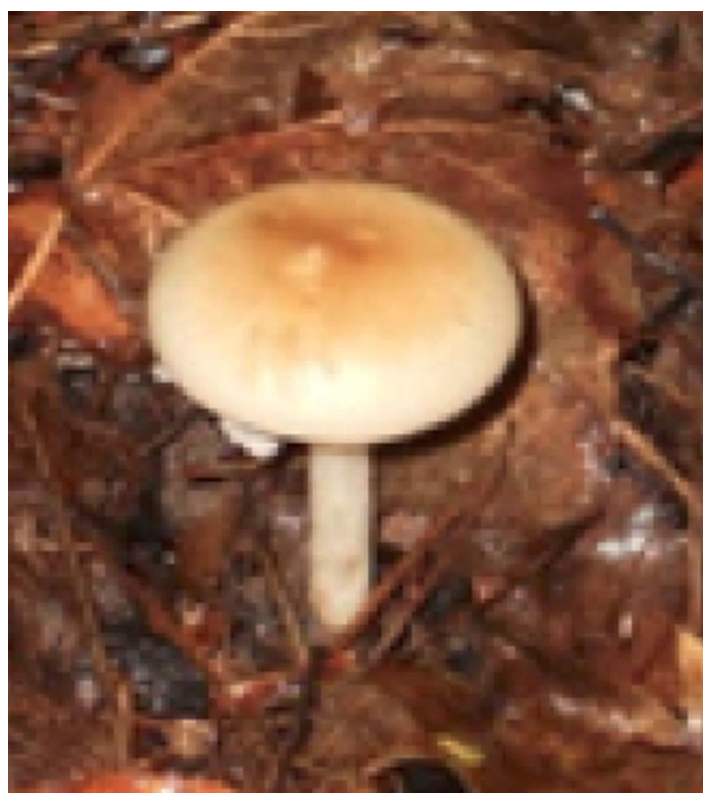

Figure 28. Mushroom found in Sacred Grove (photo by Robert Beckstead)

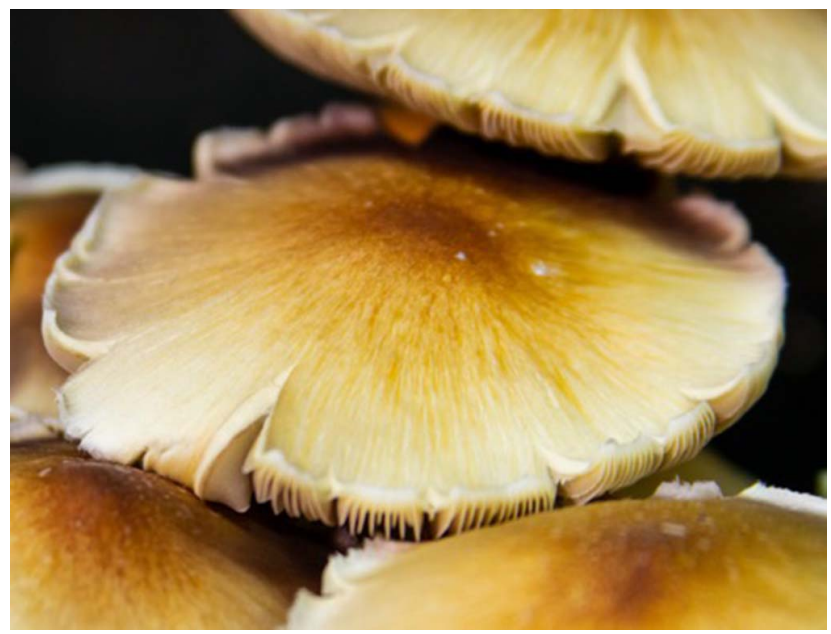

Figure 29. Psilocybe species (Shutterstock photo)

in Figure 28. The photographed mushroom in the sacred grove appears suspiciously like a Psilocybe species mushroom in Figure 29; unfortunately, no field-testing for the typical blue reaction to pressure was conducted.

\section{Entheogenic replication of Smith's first vision}

Many examples of entheogenic experiences are reported in peer-reviewed literature and on the internet that bear a striking similarity to those of Joseph Smith. For example, religious historian Huston Smith initiation into "ultimate reality" was occasioned by a psilocybin-containing mushroom. Huston reports:

What the day accomplished, ... was to enable me for the first time to experience the respective levels of the Chain [of Being], all the way to its top. The dominant effects of the experience were two: awe (which I had known conceptually as the distinctive religious emotion but had 
never before experienced so intensely) and certainty. There was no doubting that the Reality I experienced was ultimate. That conviction has remained. (2001, p. 126)

In the same year (1961), Huston ingested peyote cactus and reported: "I noted mounting tension in my body that turned into tremors in my legs ... I [began] experiencing ... the clear, unbroken Light. I was now seeing ... with the force of the sun, in comparison with which everyday experience reveals only flickering shadows in a dim cavern ... [I saw] worlds within worlds" (2000, p. 11). Smith concluded that using entheogenic substances can occasion an experience with a form indistinguishable from those of the experiences of religious mystics.

Heinrich (2002, pp. 201-203) ingested A. muscaria as the entheogenic facilitator and reported:

- I felt like I weighed thousands of pounds and could no longer sit up.

- [In] a great darkness and a great silence, the heavens opened above my head.

- The bliss I had experienced prior to this new revelation now paled to insignificance in an immensity of light that was also the purest love.

- The absolute profundity of the experience cannot be denied, neither can be adequately expressed, though one is moved to try.

Huston's and Heinrich's entheogenic reports reveal the core features of Smith's earlier vision: an experience of physical heaviness, visual darkness, an awe-inspiring light from above, a voice out of heaven, experience with the unfathomable Godhead and feelings of unspeakable joy.

\section{Joseph Smith's actual first vision}

His "actual first vision" and a vision of a divining instrument, a "seer stone," initiated Joseph Smith's career as a visionary scryer. Mormon historians connected this seer stone vision, in which Smith saw "a small stone... [which] became luminous, and dazzled his eyes, and after a short time it became as intense as the mid-day sun," with his theophanic "first vision," linking the visions conceptually and placing them in roughly the same time frame (Bradley, 2010; Purple, 1877).

Smith's understanding of his white seer stone as the white stone of Revelation 2:17 also connects it with the white stone of Hiram Abiff and, therefore, the "hidden manna" mentioned in the Masonic degrees and thought to have been administered in the more esoteric versions of those degrees.

It was from underneath of the acacia sprig, believed to be an entheogenic symbol in masonic lore, that Hiram Abiff's remains and "jewel" were reportedly excavated (Bernard, 1829). Conflating "jewel" and "white stone," Smith may have conceived of Hiram Abiff"s body and "white stone" being recovered together from under the tree. The acacia marking the burial site of Hiram Abiff's body and "jewel" is understood in freemasonry as a "tree of life" (referenced below).

Joseph Smith reported excavating under a tree to find his white stone, recalling the excavation of Hiram's white stone under the acacia tree. After recovering this stone, Joseph Smith placed it in the darkness of his hat, looked into it, and discovered that he had acquired "one of the attributes of
Deity, an All-Seeing Eye" (Bradley, 2010; Purple, 1877) reflecting another probable occasion on which he ate from an entheogenic plant. Joseph Smith, eating from such "tree of life" anticipated The Book of Mormon's descriptions of an entheogenic "tree of life," discussed below.

\section{Indian visions}

Joseph Smith's next vision in 1823 is notable for the postvision weakness and its ancestral Amerindian content. The many ancestral Amerindian tumuli found and excavated in New York and Ohio undoubtedly fascinated the young Joseph, as did the widely held belief that Amerindians were the remnants of Lost Tribes of Israel. However, as he had 3 years previously, Joseph's vision was preceded by fervently asking forgiveness of his sins. When the vision opened, a brilliant light appeared; and in the light, Joseph claimed that he saw an angel, identified as an ancestral Amerindian, with whom he spent the entire night. "I discovered a light appearing ... until the room was lighter than at noonday, when immediately a personage appeared at my bedside, standing in the air... his whole person was glorious beyond description, and his countenance truly like lightning. The room was exceedingly light... When I first looked upon him, I was afraid. [And he] said there was a book deposited, written upon gold plates, giving an account of the former inhabitants of this continent' (Smith, 1830, front piece). Following these visions, Joseph arose to work on the family farm but on meeting his father in the field, "found [his] strength so exhausted as to render [him] entirely unable" to labor.

\section{PSYCHEDELICS IN THE BOOK OF MORMON}

Several lines of evidence in The Book of Mormon suggest Joseph Smith's awareness of psychedelics and their effects. The Book of Mormon functioned as sacred scripture and acted as a psychopomp for early Mormon converts seeking direct and personal experience with God under the influence of entheogenic material. Consistent with this view, Mormon Jungian psychiatrist Groesbeck (2004) argues for The Book of Mormon as "symbolic history." We suggest that passages in The Book of Mormon and other early Mormon sacred writings guide spiritual experiences as outlined by Leary, Metzner, and Alpert (1964) in discussing the Tibetan Book of the Dead - to establish a setting for predisposing early Mormon converts to direct and personal experience with God through spiritual ecstasies. Another aspect of the set and setting of early Mormon visionary experience is Joseph Smith himself - as the archetypal shaman. Leary et al. (1964) emphasize the need for " $a$ trusted person ... to remind and refresh the memory of the voyager during the experience." Smith was that trusted person.

Herbs, although not frequently mentioned in The Book of Mormon, are highly endorsed as medicines explicitly and entheogenic substances implicitly. For instance, The Book of Mormon speaks of the "excellent qualities of the many plants and roots which God had prepared to remove the cause of diseases" (Smith, 1830, p. 353). We argue here that Smith, in The Book of Mormon, intended to reference not only the treatment of bodily diseases but also maladies of the soul. 
While traditional herbs may be useful for treating ailments relating to the body, it is the entheogenic herbs that lift the mood and relieve despair, as demonstrated after partaking of unusual fruit described in Joseph Sr.'s entheogenic dream discussed above and in The Book of Mormon tree of life allegory discussed below. Also, in The Book of Mormon, Smith associates the use of herbs with symptomatology such as

- death-like experience lasting days rather than hours,

- symptoms resulting in sensations of tongue swelling,

- sensations of motions,

- taste of light,

- enlightenment, and

- mood elevation.

These symptoms, in our view, demonstrate that Smith encoded his entheogenic knowledge encoded in The Book of Mormon.

\section{Death and rebirth symbology (ego death)}

Mormon historian Don Bradley (2019) interprets that Joseph Smith's first vision is an initiation or endowment transforming an unaccomplished young man from an improvised family into religious royalty as a seer and prophet. We argued here that Smith's first vision, facilitated by an entheogen, corresponds to similar royal entheogeninfused death and rebirth initiation rituals. Knight and Lomas (1996) explain:

The new king would have undergone 'death' by means of a potion administered by him to the high priest in the gathering of the inner group of the holders of the royal secrets. This drug would have been a hallucinogenic that slowly induced a catatonic state, leaving the new king, as inert as a corpse. (p. 145)

An entheogenic initiation of this nature would change the thoughts and feelings previously held by the new king. Two Book of Mormon narratives reflect entheogen-infused royal initiation rites discussed by Knight and Lomas. In the first narrative, after being chastised for unrighteousness,

[The King] fell unto the earth, as if he were dead ... for the space of two days ... under the power of God... and the light which did light up his mind ... had infused such joy into his soul (276-7) [and similarly, the Queen then arose and] ... cried ... O blessed Jesus... [clasping] her hands, being filled with joy. (pp. 278-279)

In the second narrative, the son of a Prophet King unprepared to succeed him on the throne is reprimanded by his father. In this account, the son reported:

I fell to the earth; and it was for the space of three days and three nights, that I could not open my mouth; neither had I the use of my limbs ... I [thought] that I could ... become extinct both soul and body... [after three days and three nights] I cried within my heart, 0 Jesus, thou Son of God, have mercy on me, ... and when I thought this, ... I was harrowed up by the memory of my sins no more. And 0, what joy, and what marvelous light I did behold; yea, my soul was filled with joy as exceeding as was my pain. (pp. 324-325)

These remarkable narratives in The Book of Mormon parallel the first-vision accounts given by Joseph Smith supporting the thesis that his first vision was an entheogen-infused initiation. In his first vision,

1. Smith felt profound guilt and shame associated with his sin (Smith, J., 1832, p. 6),

2. He was in mortal fear of "sudden destruction" (Smith, J., 1839-1841, p. 3),

3. When Smith came to himself, he "was sprawling on [his] back and it was some time before [his] strength returned" (Smith, J., 1842, p. 748).

4. Afterward, he had feelings of "calmness and peace, indescribable" (Pratt, 1840, p. 7).

We suggest that more than coincidence, Joseph Smith's first vision, The Book of Mormon death and rebirth accounts parallel Knight and Lomas' entheogen-infused royal initiation rite. It seems reasonable to conclude that Smith's experience and The Book of Mormon accounts were related to esotericism and entheogens.

\section{Synesthesia}

One feature of visionary experiences reported in The Book of Mormon, synesthesia (the stimulation of one sense modality provoking sensation in another) strongly suggests the effect of an ingested entheogen. In The Book of Mormon, Joseph informs the convert that after ingesting the seed of the fruit of the tree, they should expect it to feel "swelling" within the chest closely followed by "swelling motions." After the onset of the swelling motions, Smith informed converts to expect the appearance of light that "enlightens the understanding" so the "mind doth begin to expand," i.e., experiences the desired psychedelic properties of the seed. This mind expansion is accompanied, according to Smith, by the taste of light suggesting the phenomena of psychedelic associated synesthesia: "when you feel these swelling motions ... it beginneth to be delicious ... ye have tasted this light" (Smith, 1830, pp. 315-316).

Two examples will be most relevant here: Lehi's dream of the tree of life and Alma's parable of a seed that grows into a tree of life. Joseph Jr. inserts into The Book of Mormon a vision of an Edenic tree its fruit, and upon ingesting it, the profound experience of the love of Godnearly identical to his father's Edenic vision in 1811 (Smith, 1830, pp. 18-21). Another probable reference to synesthetic bodily symptoms in the text of The Book of Mormon appears in a parable by the prophet Alma comparing God's word to a seed. The parable describes the cultivation of a plant from seed, ultimately to a full-grown tree revealed to be, like Lehi's, "a tree of life" bearing fruit.

Now, we will compare the word unto a seed. Now, if ye give place, that a seed may be planted in your heart, behold, if it be a true seed, or a good seed, if ye do not cast it out by your unbelief, that ye will resist the Spirit of the Lord, behold, it will begin to swell within your 
breasts; and when you feel these swelling motions, ye will begin to say within yourselves-It must needs be that this is a good seed, or that the word is good, for it beginneth to enlarge my soul; yea, it beginneth to enlighten my understanding, yea, it beginneth to be delicious to me. (Smith, 1830, p. 315)

The effects of cultivating this seed expand the mind, enlarge the soul, stimulate the taste of light, and produce inexpressible joy and happiness. In these passages, Joseph Smith encapsulated the very meaning of the current meanings of "psychedelic" and "entheogen." More importantly, at least as far as Joseph Smith is concerned, the reader of The Book of Mormon is invited in this passage to experience the same psychedelic or entheogenic enlightenment, synesthesia, and transformation as he had.

\section{Mood elevation}

Descriptions of the visionary dreams of Joseph Smith's father, and his first vision, his Indian visions, and early Mormon visions in Kirtland Ohio (discussed below) manifest mood-elevating properties. The mood-elevating effects of entheogens are well established: eventually, they will be one modality of managing treatment-resistant depression (see articles in Winkelman \& Sessa, 2019). The antidepressant effects of psychedelic experience suggest motivational salience for entheogen use throughout history and specifically in the Smith family to facilitate visionary experience and as antidepressants. La Barre (1947) observed that Native American peyote use in religious confessionals provided a primitive form of psychotherapy. Similarly, the mood-elevating sequelae of Joseph Smith's use of entheogens in early Mormon rituals and confessionals was practical psychotherapy for early Mormons; and likely unconscious salience for conversion to Mormonism and convert resilience during the hardships of Mormon diasporas.

\section{Entheogenic ordinances}

In early Mormonism, converts anticipated visions and direct face-to-face communication with God, but only in the context of Church ordinances administered by Joseph Smith. In 1832, Joseph Smith explained:

And this greater priesthood administereth the gospel and holdeth the key of the mysteries of the kingdom, even the key of the knowledge of God.- Therefore, in the ordinances thereof, the power of godliness is manifest; and without the ordinance thereof, and the authority of the priesthood, the power of godliness is not manifest unto men in the flesh; for without this no man can see the face of God, even the Father, and live. (Smith, 1833, Section 4)

Importantly, visions and ecstasies in early Mormonism are associated with ordinances involving the serving of bread and wine sacraments, and anointings of bodies with anointings; while the expected visionary Nauvoo temple endowment also features oil anointings but adds plucking fruit from tree branches. In June, Joseph Smith (1839, pp. 17-18) told trusted leaders:

God hath not revealed anything to Joseph, but what He will make known unto ... the least Saint ... for the day must come when no man need say to his neighbor, 'Know ye the Lord; for all shall know ... [he] will have the personage of Jesus Christ to attend him ... and the visions of the heavens will be opened unto him, and the Lord will teach him face to face.

It is likely that models of Biblical visions, and esotericminded mentors guided Joseph Smith to ingest something crucial to his own visionary experience.

- Genesis 2:17 pointed to the need to eat the fruit of any tree in the garden to retain peace, happiness, and tranquility (possibly A. muscaria), but not the fruit of the tree of knowledge (possibly datura).

- Moses instructed Israel to eat manna that tasted like a wafer made with honey (Exodus 16:31).

- Ezekiel (3:1-3) eats a scroll that was as sweet as honey in Ezekiel 3:1, the consumption of a scroll or book tasted "as honey for sweetness."

- John, in association with his vision in Revelations 10:10, eats an entheogen that tastes sweet but in "belly [it] was bitter."

- Jesus said, "To him who conquers I will give some of the hidden manna, and I will give him a white stone" (Revelation 2:17, see also 10:9).

In each of these cases, the ingestion of some substance tasting bitter, sweet, or forbidden was transformative. Gastrointestinal upset is a feature of ergot alkaloids (Schiff, 2006), Psilocybe species, and A. muscaria mushroom ingestion (Beug, Shaw, \& Cochran, 2006). Also, Smith expounded on the Revelation of St. John, explaining that "the little book which was eaten by John, as mentioned in the 10th chapter of Revelation" is understood to be "an ordinance." In this statement, Joseph Smith informs converts that visions are associated with consuming a substance or the application of anointing oil during Mormon ordinance work.

\section{EARLY CONVERT VISIONS}

As a budding prophet, Joseph Smith's altered appearance was readily apparent to observers (see Sally Heller above), but with experience, his demeanor during visions did not so readily betray an altered state.

Early Mormon converts, as novice prophets themselves, would experience altered states similar to those reported by Joseph Smith in his early visions.

For instance, in an 1832 shared experience Joseph Smith and his first counselor, Sidney Rigdon alternately related what they saw in vision while others wrote the revelation down. As was the customary order of the priesthood at that time, Smith and Rigdon likely partook of the sacrament at the beginning of this meeting. After this vision, Sidney appeared pale and exhausted. 
As a budding prophet, Joseph Smith's altered appearance was readily apparent to observers (see Sally Heller above), but with experience, his demeanor during visions did not so readily betray an altered state. Early Mormon converts, as novice prophets themselves, would experience altered states similar to those reported by Joseph Smith. For instance, in an 1832 joint vision reported orally by both Joseph Smith and Sidney Rigdon each taking turns and witnessed by several others, likely after partaking of the sacrament that was the custom, Sidney appeared exhausted. An observer reported: "Joseph sat firmly and calmly all the time in the midst of a magnificent glory, but Sidney sat limp and pale, apparently as limber as a rag, observing which, Joseph remarked, smilingly, 'Sidney is not used to it as I am" (Dibble, 1892; for a description of this vision, see Smith, 1835, pp. 225-231; Woodward, 2012).

Joseph Smith's and Sidney Rigdon's account of this vision was added to the Latter-day Saint canon as Doctrine and Covenants, currently Section 76. This vision entailed a physical change, elsewhere called "transfiguration," a change that converts would experience in their own bodies in connection with priesthood ordinances, if they desired to see God and Heaven. According to Smith, such a transformation of the body was needed so that "while in the flesh, they may be able to bear his presence in the world of glory" (D\&C 76:117-118; Moses 1:11, 31). Smith taught that Mormon ordinances and "transfiguration" were prerequisite to visionary experience. Partaking of an entheogen would account for the physical symptoms experienced by Sidney Rigdon and other early Mormon converts and also account for the "transfiguration" phenomenon. Early Mormons were led to understand that distressing bodily symptoms following sacraments and anointing were nothing to fear but instead to eagerly anticipate.

Early Mormon converts prepared for entheogenic Church ordinances in several ways. Many of the most ardent early Mormon converts joined Mormonism after hearing of convert visions and after reading The Book of Mormon, which itself has multiple allusions to entheogenic experience. These allusions, we argue, prepared converts to experience similar entheogenic interactions with Heaven and divine beings. Among the significant exhortations Joseph Smith gave on this topic did not have so much to do with personal worthiness as it did by a willingness to participate in the ordinances and loyalty to the Church and himself. If a member remained loyal, Smith in effect guaranteed their personal and immediate success in accessing Heaven and angels and receiving revelation themselves.

Smith's promise that converts would see God and experience visions, dreams, and ecstasies would occur in receiving sacraments and endowments. The settings where sacraments were received were initially nature-based, followed by private homes; and later shifted to specially constructed temples incorporating mystical symbols, including symbols utilizing esoteric and masonic imagery. For instance, labyrinths, gonfalons, spirals, and squares within squares adorned the Kirtland temple. Even more mysterious, unquestionably alchemical-masonic symbols decorated the Nauvoo temple. Further, Joseph Smith himself was the trusted guide for ceremonies, prayers, and singing; and when necessary, Smith managed problematic entheogenic experiences. By following this entheogenic protocol, Joseph Smith facilitated an unprecedented number of "on demand" religious visions and ecstasies.

\section{Three witness' visions}

The type and quality of visionary experience among Mormon converts was similar to that experienced by Joseph Smith, including the replication of the troublesome symptomology reported by Smith. Converts receiving visions containing doctrine and commandments that contradicted that of Joseph Smith, however, were tightly controlled by him and non-binding on the Church (Smith, 1835, p. 181).

In July 1829, shortly after Joseph Smith completed his work on the text of The Book of Mormon, Oliver Cowdery, David Whitmer, and Martin Harris accompanied Joseph Smith in prayer and Cowdery, Whitmer, and Smith, and then separately Harris and Smith, experienced visions of an angel descending from Heaven and showing the golden plates and other artifacts associated with The Book of Mormon, a testimony they never recanted even when ridiculed.

However, considerable controversy raged in the 19th century and today about whether the witnesses saw the plates in a physical, sensory way (with "natural eyes") or in an altered, visionary state (with "spiritual eyes"). One witness, Martin Harris, equivocated on whether the experience was "natural" or "spiritual." Further light was shed on the experience by another witness, David Whitmer: "I have been asked if we saw those things with our natural eyes. Of course, they were our natural eyes. There is no doubt that our eyes were prepared for the sight, but they were our natural eyes nevertheless" (Vogel, 2003). Of particular interest to this discussion is David Whitmer's statement that: "our eyes were prepared for the sight." In 3 Nephi 28 found in The Book of Mormon, Joseph Smith's reveals that the physical body must change, or "transfigure" to see spiritual things or else they would die (Moses 1; 3 Nephi 28). From Whitmer's testimony, it appears that The Book of Mormon witnesses were informed by Joseph Smith either directly or in the form of The Book of Mormon passages that symptomology precedes visionary experience.

The Three Witnesses and Mormon converts alike were aware of the biblical precedent involving Adam and Eve eating the "forbidden fruit." Another precedent involved the practice of receiving communion, in which ordinary food and drink received an Apostolic blessing leading to those present at the visionary Christian Pentecost to appear intoxicated. The telling of Joseph Smith Sr's. entheogenic dreams and the entheogenic accounts in The Book of Mormon would also have provided yet another precedent. All of these precedents, and others discussed in this paper, placed in the immediate backdrop of their vision, provided "emotional immunization" from fear and embarrassment secondary to the troublesome entheogen-related physical and emotional symptomology preceding their visionary and ecstatic experience.

\section{0: New York visions}

Joseph Smith promised converts visions, but only in Mormon "ordinances" and in the presence of Church leaders. In the first conference of the Church held on June 9th of 1830 
in Fayette, New York, organizing his Church, Smith formalized the instructions to "oft" partake of the sacrament. Of this meeting, Joseph Smith wrote:

... we partook together of the emblems of the body and blood of our Lord Jesus Christ ... Much exhortation and instruction were given; and the Holy Ghost was poured out upon us in a miraculous manner many of our number prophesied, whilst others had the Heavens opened to their view, and were so overcome that we had to lay them on beds, or other convenient places: Among the rest was Brother Newel Knight who had to be placed on a bed, being unable to help himself. By his own account of the transaction, He could not understand why we should lay him on the bed, as he felt no sensibility of weakness. He felt his heart filled with love, with glory and pleasure unspeakable, and could discern all that was going on in the room, when all of a sudden, a vision of futurity burst upon him. He saw there represented, the great work which through my instrumentality was yet to be accomplished. He saw Heaven opened and beheld the Lord Jesus Christ, seated at the right hand of the majesty on high, and had it made plain to his understanding that the time would come when he would be admitted into his presence to enjoy his society for ever and ever. When their bodily strength was restored to these brethren, they shouted, "hosannas to God and the lamb" and rehearsed the glorious things which they had seen and felt, whilst they were yet in the Spirit. (Smith, 1843, pp. 41-42)

The relationship of the symptomology associated with this visionary experience highly suggests Joseph Smith surreptitious use of entheogenic material in the Mormon sacrament ordinance. Further, symptomology associated with Mormon visionary experience likely results in charges of medicating or doctoring the wine. Seeming to deflect this criticism onto those making the charges, Smith warned members in August 1830 they should not "partake" of wine "except it is made new among you" (Smith, 1835, p. 27). As he will do again in 1833, and in 1836 (see below), Joseph seems to suggest that any wine he administers during Mormon ordinances will be new wine, consecrated, and non-intoxicating.

\section{0-1831: Kirtland, Ohio, charges of intemperance}

When Joseph Smith arrived in Kirtland, Ohio in 1831, converts had experienced visionary sacraments similar to that witnessed in New York. How did these Mormons, having not met Joseph Smith, institute an entheogenic sacrament? Mark Staker (2009, pp. 19-26) in his "Hearken, O Ye People" contextualizes the episode in 19th-century African American worship practices and the enthusiasms of the Second Great Awakening. However, there are reasons to believe that "wild enthusiasms" associated with early Mormon visionary meetings were more than just such reflections. For instance, a medically trained school teacher, Jesse Moss, who knew the nature of religious enthusiasms, reported that Mormon enthusiasms far exceeded those of the Methodists. A more likely possibility for early Mormon wild enthusiasms is one of the four Mormon missionaries who visited Kirtland and departed before the onset of the
Mormon excesses described below. Mormon missionaries, including Frederick G. Williams (see above), stopped in Kirtland on their way to Independence, Missouri. In Kirtland, they converted most of Sidney Rigdon's Campbellite congregation, including Isaac Morley and Peter Kerr.

\section{Unusual manifestations}

In his book, Hearts Made Glad: The Charges of Intemperance. Against Joseph Smith, the Mormon Prophet, author Lamar Petersen noted during the early days of the Church there were "unusual spiritual manifestations" associated with the drinking of sacramental wine, behaviors of such a shocking nature it "impaired the image of the young Church among sober people" (Petersen, 1975, p. 79). According to Moss (1913), a medically trained school teacher in Kirtland, Ohio, offered testimony that Mormons,

took what was called the sacrament up at the [Isaac] Morley house. They were in the habit of turning everybody out of the door when they partook of the bread and wine, putting blankets up at the windows, shutting off the sight from without ... then [later] they opened the door and let us all come in again. [The] poor-house in Portage County, Ohio, where there were half a dozen insane and idiotic persons, was the best comparison of anything to the scene that night. And if I had had my cloak on, I would have stolen the wine and carried it home to see whether it was drugged or not. (p. 384)

William S. Smith, testifying after Moss, supported the recollections of Mr. Moss:

I have attended the meetings at Mr. Morley's... in the house I have seen young men and women seemingly unconscious, and the folks said they had lain so for two days and they were there on their beds, and nobody tried to prevent us looking at them, but we were not allowed to go into the room. (Ibid, p. 888)

On another occasion, Moss concluded that Mormon sacrament meetings "exceeded the wildest scene ever exhibited among the Methodists" and instead "became fully satisfied the wine was medicated," even attempting to secure a bottle for testing but was unsuccessful (Moss, 1878). Petersen also noted that "the catalepsy could, of course, have been induced without the aid of wine [but the scene was] reminiscent of the first conference of the Church a year earlier at Fayette, New York." That Moss indicated that Mormon enthusiasms exceeded that of the Methodists and lasting 24-48 hr, strongly supporting this conjecture of Smith including psychoactive substances in the sacraments.

Joseph Smith arrived in Kirtland, Ohio after the incidences discussed above but in time to preside over the June 6th, 1831 Elders conference. According to Levi Hancock (1858, p. 90) who was present as this meeting:

Joseph put his hands upon Harvey Whitlock and ordained him to the high Priesthood he [Whitlock] turned as black as [Lyman Wight] was white his fingers was set like Claws he went around the room and showed 
his hands and tried to speak his eyes were in the shape of Oval O's. Hyrum Smith said Joseph that is not God. Joseph said do not speak against this. (Ibid)

It is likely that Joseph Smith, had considerable experience with entheogens, is not concerned with the chaos they create, and is reluctant to attempt to intervene. However, Joseph's brother was not convinced:

I will not believe ... unless you inquire of God and owns it. [At this] Joseph bowed his head, and in a short time got up and commanded Satan to leave Harvey, laying his hands upon his head at the same time."... [Then] Copley, who weighed over two hundred pounds, somersaulted in the air and fell on his back over a bench. Wight cast Satan out of Copley, and Copley was calmed. The evil spirit, according to Hancock, was in and out of people all day and the greater part of the night. (Ibid)

Taken together, the events of the 1830 and 1831 conferences strongly suggest entheogenic influence and compares well with Joseph Smith's earlier entheogenic-facilitated early visions (Smith, 1830, pp. 276-267, 324-325).

\section{Negative publicity}

A letter to the editor of Palmyra Reflector, published in January 1831, accused Joseph Smith of legerdemain. Since this term referred then, as now, to "Sleight of hand; a deceptive performance which depends on dexterity of hand; a trick performed with such art and adroitness, that the manner or art eludes observation" (Webster, 1828), its use in this context may reflect ongoing accusations that Joseph Smith was manipulating the sacramental wine.

Sacramental wine was not the only possible carrier for an entheogen enhancing early Mormon sacramental experience. We have noted the entheogenic potential of ergotinfected rye, possibly mixed with the sacramental bread, like that which may have induced preternatural experiences in the life of Joseph Smith's great grandfather Samuel Smith. As we will see in discussing Mormonism's 1840s Nauvoo, Illinois period, ergot-infected rye was widely used as a medicinal remedy in Joseph Smith's day and may also have lent itself to more spiritual uses.

Complaints about Mormon enthusiasms drew the attention of the nation's newspapers. For instance, in the September 1831 edition of the Vermont Gazette (Bennington, Vermont), published a letter to the editor reporting: "Some [Church members] lie in trances a day or two and visit the unknown regions in the meantime; some are taken with a fit of terrible shaking which they say is the power of the Holy Ghost" (Kirkham, 1959). A trance lasting 24-48 hr is highly suggestive of $D$. stramonium intoxication (Bryson, 1996, p. 673; Wiebe, Sigurdson, \& Katz, 2008). The Independent Gazetteer (Taunton, Massachusetts) reported on January 11, 1833 that during Mormon meetings there would be "shoutings, wailing, fallings, contortions, trances, visions, speaking in unknown tongues and prophesying" (Morgan, n.d.). Also, Henry Caswell (1843, p. 63) wrote of "a pretended sacrament" associated with manifestations of power in early LDS meetings. A pretended sacrament, although not stated explicitly, suggests drugged wine. So vociferous were Mormon critics that local Church leaders became alarmed and complained to Joseph Smith of similar undisciplined scenes. Table 2 summarizes what was reported by church leaders.

Although Joseph Smith chastised Isaac Morley in whose house many of the sacrament meetings occurred, Smith failed to acknowledge their similarity to his own first 1820 vision of God, his 1823 visions of an angel and golden plates, and the 1829 scrying visions while translating The Book of Mormon. Similar problematic scenes beset meetings Smith conducted. At Kirtland sacrament meeting in 1831, Joseph Smith suggested imminent mass visions and promised Lyman Wight he would have a vision of Christ. Mormon historian, Richard Bushman, explains what happened next: "Wight turned stiff and white, exclaiming he had indeed viewed the Savior ... Joseph himself said, 'I now see God and Jesus Christ'... Then Harvey Whitlock ... turn as black as Lyman was white ... his fingers were set like claws. He went around the room and showed his hands and tried to speak, his eyes were the shape of ovals "O's"... [Then] Leman Copley, who weighed over two hundred pounds, somersaulted in the air and fell on his back over

Table 2. Comparison of converts undisciplined scenes and Joseph Smith's first vision

Church leader reports

George A. Smith (1867)

David Whitmer ("John Whitmer,

History," 1831-ca. 847)

Parley P. Pratt (Bushman, 2005, p. 151)

Joseph Smith's First Vision (from Table 1)
Undisciplined scenes

Unnatural distortions

Extravagant and wild ideas

Wielded the sword of Laban as expertly as a light dragoon

Acted like an Indian ... scalping

Slid on the floor with the rapidity of a serpent, sailing in boats to preach to the Lamanites

Swoons

Unseemly gestures

Cramps

Falling into ecstasies

Insanity

Bound hand and foot in chains as immovable as a stick of timber

Getting on the stumps of trees and shouting

Pursuing balls flying in the air

Running off a cliff, nearly being killed in pursuit of a floating scroll 
a bench ... [Similar behavior was manifested by] people all day and the greater part of the night" (Bushman, 2005, pp. 156-157). These experiences, likely following the administration of the sacrament with Joseph present, are difficult to explain absent some toxidrome, yet easy to explain in the presence of one, and are strikingly similar to those described in Smith's own first vision and those that took place in early Kirtland, possibly under the direction of Peter Kerr, a former slave known as "Black Pete" in early Mormon literature.

\section{Peter Kerr}

According to Mark Staker (2009), after the missionaries left Kirtland later in 1830, 55-year-old Peter Kerr ("Black Pete") acted as "a revelator" and "a chief man" to a small Mormon community in Kirtland, Ohio, until Joseph Smith arrived in early 1831 (pp. 77, 79). Kerr was raised by a mother whose religious tradition was the syncretic African-Muslim religious tradition of what is now the Ivory Coast. When enslaved, she lived along the Monongahela River in western Virginia where Peter was likely raised in an ecstatic religious fusion of African, Baptist, and Methodist ideas that included "interacting with the spirit world, dancing in fire, and speaking in tongues" (p. 11). It is therefore likely that Kerr had exposure to African folk magic, conjure, and root medicine and knowledge of D. stramonium.

According to Catherine Yronwode, "root doctoring" mixed African magical practices with American Indian herbal medicine. Further, "most medical herbs also have magical uses, so urban conjures were able to take advantage of the medical industry's commitment to herb purity and specificity" (2002). Among the visionary materials used by Native Americans was jimson weed or D. stramonium (see Schultes, 1975), a substance also used in African medicine (Hamby, 2004, pp. 39, 54).

According to Staker (2009, p. 34), Kerr was "among those brought into the Reformed Baptist movement in early 1828 " and not until late 1830, a period of nearly 3 years, that he converted to Mormonism and "was recognized as a "revelator' among them" (Ibid, p. 119). If Kerr was solely responsible for the entheogenic-infused enthusiasms in early Mormonism, why didn't the same enthusiasms appear after he joined the Reformed Baptists in 1828? It seems more likely that one of the missionaries noted that like Joseph Smith, Kerr was a "charismatic with a distinctive religious perspective" (Ibid, p. 3) and concluded he was the logical choice to minister to converts' spiritual needs. As Staker states, "Kirtland's religious enthusiasm was similar in so many ways to the religious world Black Pete knew that it is unlikely it developed as an independent experience" (Ibid, p. 171). It would have been surprising, given Kerr's background and the likely promptings of at least one Mormon missionary, had he not utilized $D$. stramonium in his visionary syncretism.

For several months, Kerr (like Joseph Smith would do later when he arrived in Kirtland) introduced converts to entheogenic facilitated visions and spiritual ecstasies bringing many into the nascent Church. Further, like Smith's use of datura, Kerr's administration of this anticholinergic entheogen was problematic, leading to an embarrassed Church and accusations of medicated wine.
In 1833, Joseph Smith blamed the enemies of the Church for the medicated wine. In an 1833 revelation, it was advised, "in consequence of evils and designs which do and will exist in the hearts of conspiring men in the last days ... your sacraments ... should be wine, yea pure wine of the grape of the vine of your own make" (Smith, 1835, pp. 207-208).

\section{Prejudice and secrecy}

Joseph Smith's surreptitious use of entheogenic material was a closely guarded secret for obvious reasons. Although the ingestion of such substances was not illegal in the 19th century, their use was discouraged by withering ridicule. In a telling passage of The Book of Mormon, Joseph psychologically prepared early converts for the ridicule they might face and primed them to embrace it. This persecution incorporated, into The Book of Mormon that associates an entheogenic tree and the hostility of his neighbors, "And after they had a tasted of the fruit, they were ashamed, because of those that were scoffing at them" (Smith, 1830, p. 20).

Smith even faced strong opposition from his family. In a family gathering: Joseph Sr. began to speak of the discovery and translation of The Book of Mormon. At this, [his cousin] Jesse grew very angry, and exclaimed, "If you say another word about that Book of Mormon, you shall not stay a minute longer in my house, and if I can't get you out any other way, I will hew you down with my broad ax" (Smith, L. M., 1853, pp. 154-156). Although Jesse's heart eventually softened and he reconciled with his cousin, such prejudice against the visionary, magico-religious practices of Joseph Smith Jr. required that he make considerable efforts to conceal his selective use of entheogens.

\section{3: Kirtland, Ohio School of the Prophets and the Mormon Pentecost}

In 1833 , visionary endowments associated with washings, anointings, and sacramental wine during sessions of the "School of the Prophets." For example, in a March 1833 meeting of high priests, "Bro Joseph ... [gave] a promise that the pure in heart that were present should see a heavenly vision ... after which the bread and wine was distributed by Bro Joseph after which many of the brethren saw a heavenly vision of the savior and concourses of angels and many other things" (Roberts, 1902). During this period, on-demand visions again suggest the administration of an entheogen. Mormon elder Zebedee Coltrin reported Joseph Smith confidently promising Coltrin and Oliver Cowdery, "Now brethren we will see some visions," after which Smith verbally guided them through a trip to heaven, where they saw Adam and Eve seated on a golden throne that looked like a celestial lighthouse (Anderson, D. S., 2018).

Between 1833 and 1836, we have no reported visions such as seen in New York or early Kirtland period. The embarrassment to the Church and various accusations surrounding Mormon visionary experience necessitated a change in venue. Smith would build a temple to house convert visions before the next series of reports of drugged wine would emerge. 
The spiritual outpouring associated with the dedication of the Kirtland Temple in March and April of 1836 was called the Mormon Pentecost, the equivalent to the early Christian Pentecost that was also accused of alcohol intoxication. Visionary experiences during this period are linked, we argue, to the administration of bread and wine sacraments and oil anointings. Although not exhaustive, these remembrances are pertinent to the question of entheogen-infused Mormon ordinances and visionary experience.

The Kirtland temple endowments created a sacred space decorated with labyrinths, gonfalons, spirals, and squares within squares (Howlett, 2014) and a prolonged ceremony that included a day of fasting and the "reenactment of the Passion narrative and Pentecost" (Olaiz, 2014) that included the washing of feet and anointing the head with holy oil. In the evening, the fast was broken with a communion of bread and wine as a "reenactment of the Last Supper" followed by a ceremony that "mimicked the high point of Christian redemption ... they stayed up all night ... a re-enactment of Gethsemane" (Ibid). In serving the wine, Joseph Smith explained, "the wine was consecrated, and would not make them drunk ... they began to prophesy, pronouncing blessings upon their friends" (Harris, 1841, p. 32).

With increasing confidence in his entheogenic sacraments, Joseph Smith enabled hundreds to received visions during the dedication ceremonies of the Kirtland temple, but only if willing to participate in the Mormon ordinances. Smith's exuberance, however, was tempered as the manifestations of anticholinergic toxidromal symptoms led, once again, to accusations of drugged wine. For instance, a Church member with the last name of McWhitney complained that the wine consumed in the temple ordinances was actually "mixed liquor" and that "the Mormon leaders intended to get the audience under [its] influence" so visions experienced were believed to be of "the Lord's doing" (1888, p. 135). John W. Gunnison interviewed the Church elders present at the 1836 Kirtland Pentecost and reported: "Wine was administered... that had been consecrated and declared by the Prophet to be harmless and not intoxicating. This ... produced unheard of effects, if we may credit the witnesses of these proceedings. Visions, tongues, trances, wallowings on the ground, shoutings, weeping, and laughing, the outpouring of prophecies ... these and other fantastic things were among 'the signs following' at Kirtland" (Gunnison, 1852, p. 107)

Even though descriptions of visions and ecstasies associated with entheogenic sacraments and anointings at the Kirtland temple were inspirational and stirring, problems developed almost immediately. Soon afterward accusations of adultery beset Joseph Smith as did challenges to his leadership, a Mormon war in Missouri, and the failure of the Kirtland Anti-Bank society. These catastrophes would occupy Smith's attention and prevent him from creating an environment suitable for entheogen administration. It would not be until the Smith had established the City of Nauvoo, formed the Nauvoo Legion to protect him and the Saints, and completed a new temple would he again promise mass visionary experience.

\section{2: NAUVOO TEMPLE}

In 1841, Joseph Smith laid the cornerstone of a new temple in Nauvoo, Illinois, and in May of 1842, Smith taught a lengthy Masonic-like initiation rite to trusted leaders. The purpose of the training was to prepare for the dedication of the temple (Smith, 1977, p. 237). Since the temple was not completed and likely not wishing to repeat the embarrassment associated with the open access to the Kirtland visionary period, there were no visions during this initial endowment, and there were none promised. However, the expected endowment planned for the completed Nauvoo would eclipse those of the Kirtland Pentecost. Smith explained,

I spent the day ... instructing them in the principles and order of the Priesthood, attending to washings, anointings, endowments ... by which anyone is enabled to ... come up and abide in the presence of the Eloheim ... [as] soon as they are prepared to receive, and a proper place is prepared to communicate them, even to the weakest of the Saints [see D\&C 89:3]; therefore let the Saints be diligent in building the Temple. (Smith, 1977, p. 237)

\section{The Edenic tree}

The organization and context of the anticipated Nauvoo endowment provide for the covert administration of entheogenic anointings and sacraments, although for this endowment, the sacrament included partaking of the fruit from the tree in the Garden of Eden. Following purifying ceremonies of washing and oil anointing, a "new name" was given to initiates, who were informed was connected with Christ's promise in Revelation 2:17 of a "white stone" (Van Dusen, 1847). Then, fruit representing the forbidden fruit of "the tree of knowledge of good and evil" was plucked from the tree and eaten by the initiate. The Nauvoo endowment would avoid the problems of mass entheogenic visionary experience by conducting initiates in small groups within the seclusion of the temple. Receiving this sacred food also fulfilled the other promise of Revelation 2:17 - that they would be given "to eat of the hidden manna." Their initiation followed both the pattern of alchemical freemasonry with its entheogenic elixir and philosopher's stone and the pattern set by Joseph Smith when he ate of "hidden manna" and acquired his "white stone." Following this, the initiates engaged in an interactive entheogenic journey through the fall of Adam and the redemption of man by Jesus Christ after which they would pass through a curtain into a beautifully decorated celestial room and the presence of God (Buerger, 2001; Hyde, 1857).

We argue that to fulfill his promise of coming into the presence of God in the Nauvoo temple, Joseph Smith would have offered:

1. An overall sense of the holy and a mindset of sacredness.

2. An impressive and uplifting multistoried edifice with esoteric symbols inside and out and multiple special purpose rooms. 
3. Trusted attendants to guide initiates through each aspect of the ceremony, to prompt attendees should they experience confusion and provide assurance if distress occurs, and

4. An entheogen that would not produce the indecorous symptoms and outside criticisms such as the Church experienced during the visionary Kirtland period.

After receiving the new name, an entheogenic anointing, and ingesting Edenic fruit, converts basked in emotional and physical safety designed to provide spiritual experiences of such consequence it would enhance the joy of living and provide comfort during periods of struggle.

\section{Nauvoo Entheogen}

The procurement of an entheogen for the Nauvoo temple would not be as easy as harvesting datura seeds found growing in the surrounding countryside and used as ornamentals in some gardens. Because of the Kirtland experience, datura as an entheogen would draw unwanted attention. And gathering enough entheogenic mushrooms for the rapidly increasing Church population, at time around 10,000, was not practical. However, several physicians in positions of Church leadership would have known about the medical use of ergot in obstetrics and could easily extract ergot's water-soluble entheogenic component. In Nauvoo, ergot was readily availability, easy to hide, and of high potency making it an ideal entheogen for burgeoning Church population. However, by 1842, two important physicians in the Mormonism, Luman Walters and John C. Bennett, became disaffected with Joseph Smith and a third, Frederick G. Williams died. Another physician, Williard Richards, may have been able fill these vacancies, but in 1843, the malpractice trial of doctor William Brinks may have persuaded Joseph that an ergot-derived entheogen could become very problematic.

A year before the 1843 trial, Dr. Brinks treated a female in labor suffering from severe pain and fever. When he treated her with ergot to hasten delivery, her womb "lacerated or ruptured" (Dinger, 2016, p. 85). In his defense, Dr. Brink explained, "I gave her ergot ... nothing but what any physician would do" (The Joseph Smith Papers, 1842-1844). However, Dr. Samuel Bennett, a traditional doctor, testified against Dr. Brink, stating that he "should not have administered ergot ... its effect on the uterus [is] to expel the contents of the uterus [or] to produce delivery," but ergot caused increased intrauterine pressure, rupture, and permanent disability (Dinger, 2016, p. 85.) The case was high drama and 3 months later, Joseph Smith meet with Native American leaders in what appear to be negotiations for a safer, more effective entheogen - peyote.

\section{PEYOTE ENTHEOGEN}

During the period of Indian Removal beginning in 1830, Native Americans living east of the Mississippi River passed through Nauvoo on their way to their seasonal hunting grounds. Potawatomi delegations, including members of the Fox and Sauk nations, visited Joseph Smith between April 18 and August 28 of 1843 (discussed below).
The purpose of these negotiations is not altogether clear to historians. However, as we will see, the negotiations probably involved Joseph Smith giving valuable and sacred property to the Potawatomi without apparent gain to Smith in return. We suggest that Joseph Smith negotiated with nearby Native Americans for the delivery of peyote to Nauvoo for the Nauvoo temple endowment.

\section{Quest for a new entheogen}

There were several groups of Native Americans living on the American Prairie in the early 19th century, any of which could have provided for the transport of peyote from South Texas. Joseph Smith has had dealings with the Prairie groups of the Potawatomi, Fox, Sauk, and Delaware (Lenape), with Smith sending missionaries to the Mahican, Sioux, and other Indian peoples residing in Wisconsin and Canada (Jensen, 2012; Mahas, 2017; Walker, 1993). Further, although few Indians joined Mormonism, there were "many among the Shawnees" who believed in Smith's mission (Byron, 1993).

\section{The Potawatomi}

The Potawatomi were an Algonquian-speaking Eastern Woodlands group related to the Ojibway, discussed in relation to $D$. stramonium and $A$. muscaria. However, with the Indian Removal Act of 1830, "the Potawatomi were removed in two groups: The Prairie and Forest Bands from northern Illinois and southern Wisconsin went to Council Bluffs in southwest Iowa, and the Potawatomi of the Woods (Michigan and Indian bands) relocated to eastern Kansas near Osawatomie" (Bassett, 2016).

Peyote "was used in ancient times in Mexico, spreading from the Rio Grande Valley and taking hold on the Plains [the American Prairie] as early as the 1840s" (White, 2011, p. 178). Peyotism existed among Native American shaman and medicine people for centuries and was likely used by Potawatomi and other Plains Indian shamans before they formally adopted the Peyote Religion in the 1890s (Stewart, 1987, p. 93). The Potawatomi passed through Nauvoo on their way to and from their hunting grounds in Iowa territory (Smith \& Edwards, 1972) and could have served as an early bridge between the Indians of the Southwest (e.g., Comanche-Osage) and Joseph Smith for the delivery of peyote to Illinois for the Nauvoo temple. Prairie Potawatomi began actively trading peyote imported from South Texas at least by 1870 (Schaefer, 2015) and perhaps even earlier (Howard, 1962).

In August 1841, a large group of Fox and Sauk Indians, including 100 chiefs, visited Nauvoo in 1841 (AppanooseBiography, n.d.) with their leader, Chief Keokuk, forming a personal relationship with Joseph Smith and his wife, Emma. Emma exchanged recipes for herbal medicines with the wife of Chief Keokuk (Newell \& Avery, 1994, p. 278). During the spring and summer of 1843, three delegations of Potawatomi traveled to Nauvoo primarily to ask Joseph Smith "for assistance and advice in their struggles with white Americans" and in April 1844, eleven Potawatomi Indians visited Smith again "seeking help to avoid losing their land" (Council of Fifty, 1844-1846). Joseph Smith had a significant number of Native American contacts during the 
Nauvoo period, any of which could have provided for the delivery of peyote to Nauvoo; we feel it was most likely with the Potawatomi.

Besides this encounter, there were additional meetings between Joseph Smith and the Potawatomi. According to LDS Church Historian Jay Todd (1968), in June 1843,

Several of the Potawatomi Chiefs called to see the Nauvoo House and Temple ... Nauvoo was a prominent spot for Indians and was called by them Quashquema ... [and] Indian burial grounds abounded in the area." However, not finding Joseph Smith present, the Potawatomi explained, "They were not free to talk, and did not wish to communicate their feelings until they could see the great Prophet." (Ibid)

They returned in July and told Smith, "We have talked with the Great Spirit, and ... the Great Spirit has told us that he had raised up a great Prophet ... We will now wait and hear your word."(Ibid) After Smith spoke, Smith had an ox killed for them and they were given fresh horses for their journey home. (Ibid)

During one of the several visits of Potawatomi to Nauvoo, Joseph possibly gave the Potawatomi captain a significant portion of the Egyptian papyri from which he "translated" a work of scripture said to have been written by the hand of the Biblical Abraham (Todd, 1969). These papyri were from a larger collection purchased by Joseph Smith in 1835 for $\$ 2,400$ (Gee, 2007; Remini, 2002, p. 105). The value of these papyri was significant since $\$ 2,400$ in 1835 represents nearly $\$ 70,000$ adjusted to 2019 value. It is a mystery why Smith would give away such valuable papyri when he anticipated showing them on display for a fee, and also anticipated translating the "Book of Joseph" from the same collection of papyri (Larsen, 1992). The gesture is striking.

Was Smith negotiating for access to Native entheogens? Such negotiation is suggested by the timing of these interactions with the Potawatomi, Fox, and Sauk, beginning within weeks of the discrediting of ergot in the Brink trial, by Smith's inordinate "gift" to these representatives, and by earlier exchanges of herbal information between the Smith family and the family of the local Sauk chief Keokuk. Acquiring Native American entheogens could have fueled a new and more profound spiritual Pentecost in the endowment to be given in the Nauvoo temple, scheduled for completion in $1845-1846$.

\section{Lyman Wight}

Joseph Smith's vision was for Mormon colonies to span the globe, with Independence, Missouri being the center of a worldwide kingdom of God. After the Mormon War of 1838, Smith moved the center of the kingdom to Nauvoo, Illinois but still sought to establish colonies adjacent to Indian Territory in areas such as California, Oregon, Minnesota, the Great Basin, and Texas (The Joseph Smith Papers, 1842-1844, pp. 55, 170, fns 46-47). Smith's emissaries also negotiated for the Neueces strip (Figure 30) in deep south Texas, an area extending from Corpus Christi down the coast to Brownsville, then westward between the Rio Neueces and the Rio Grande River.

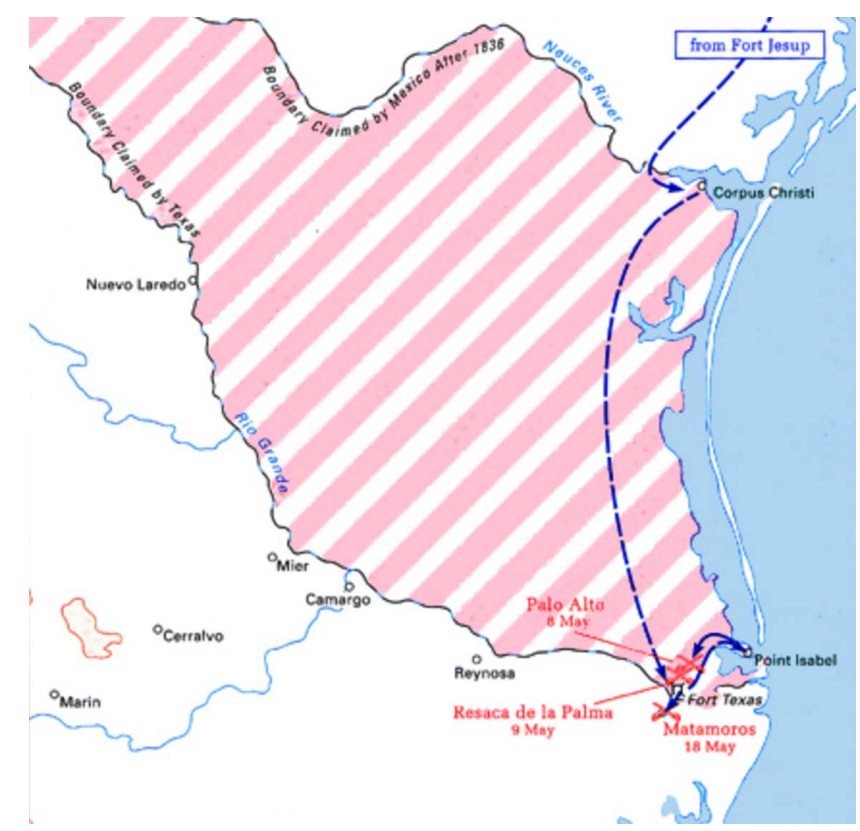

Figure 30. The Neueces strip shown in pink and white stripes. Adapted from the U.S. Army Campaigns of the Mexican War (Carney, n.d.). In Figure 25, the same area is shown in the purpleblue area.

Lyman Wight, having experienced an entheogenic vision of Christ as documented above, became a reliable friend of Joseph Smith and resolutely carried out his orders, including being part of a Mormon pinery colony in Wisconsin. Joseph Smith used such colonies, flung out from the Church's central hub at Nauvoo, to acquire resources for the main body of the Church. The Mormon colony in Wisconsin, between 1841 and spring 1845 , floated timber to Nauvoo amounting to " 1.5 million board feet of milled time, more than two hundred thousand shingles, and a large number of miscellaneous logs, barn board, and timbers" (Clark, 1997-1998, p. 67). In February 1844, Lyman Wight, in conversation with local Wisconsin Native Americans, concocted a plan to form a joint Mormon-Indian colony in Texas. Wight wrote to Smith requesting permission for himself and the Native Americans to travel to Texas to initiate such a colony (Figure 31). Smith agreed, and Wight was ordered "to take a small colony to Texas and make smooth and ready the path for a major migration of the L.D.S. church to Texas" (Banks, 1945; Johnson, 2006, p. 5). However, given the Mormon emphasis, since 1829, on building settlements near Native American lands, and given that the initial colony idea proposed by Wight was to be a Mormon-Indian colony, it seems highly probable, if not nearly inevitable, that Woodworth would have entered into contact with Native Americans there.

Joseph Smith aimed to establish colonies to procure resources for the body of the central hub of the Mormon community at Nauvoo. What resource was the planned Texas Mormon-Indian colony intended to provide? Texas was a keystone to peyotism; peyote grew in abundance in Southwest Texas, especially along the Texas-Mexico border and the Rio Grande River, with an active peyote trade that only abated in 1959 (Morgan \& Stewart, 1984). In this expedition, Joseph Smith may have attempted to plant a Mormon-Indian colony in the heart of peyote country, where 
his colony could harvest thousands of peyote buttons, just what the thousands of Nauvoo saints would need if peyote was the entheogen used in the completed Nauvoo temple.

Did Joseph Smith know he was planting his prospective colony where Mormon colonists could acquire peyote? Smith's evident use of entheogens, his need for them to replicate the Kirtland Pentecost, the timing of the Texas negotiations shortly after other potential entheogens and sources of entheogens faltered, his intention to involve Native Americans in his scheme, his pattern of planting colonies to supply resources from the local environment, and his choice of the peyote environs suggest to us his intention to use his Texas colony to supply peyote. In addition, tangible, artifactual evidence exists indicating that Joseph Smith knew and was interested in the peyote trade and had contacted a peyote trade network of Native Americans through intermediaries, or directly from the anticipated Texas Mormon colony, or both. A sacred stone found among Smith's belongings, which we will call "the peyote stone," is that artifactual evidence.

\section{Joseph Smith's Peyote Stone}

Among Joseph Smith's possessions during his death was a finely tooled sandy-colored seer stone (Figure 32), unlike

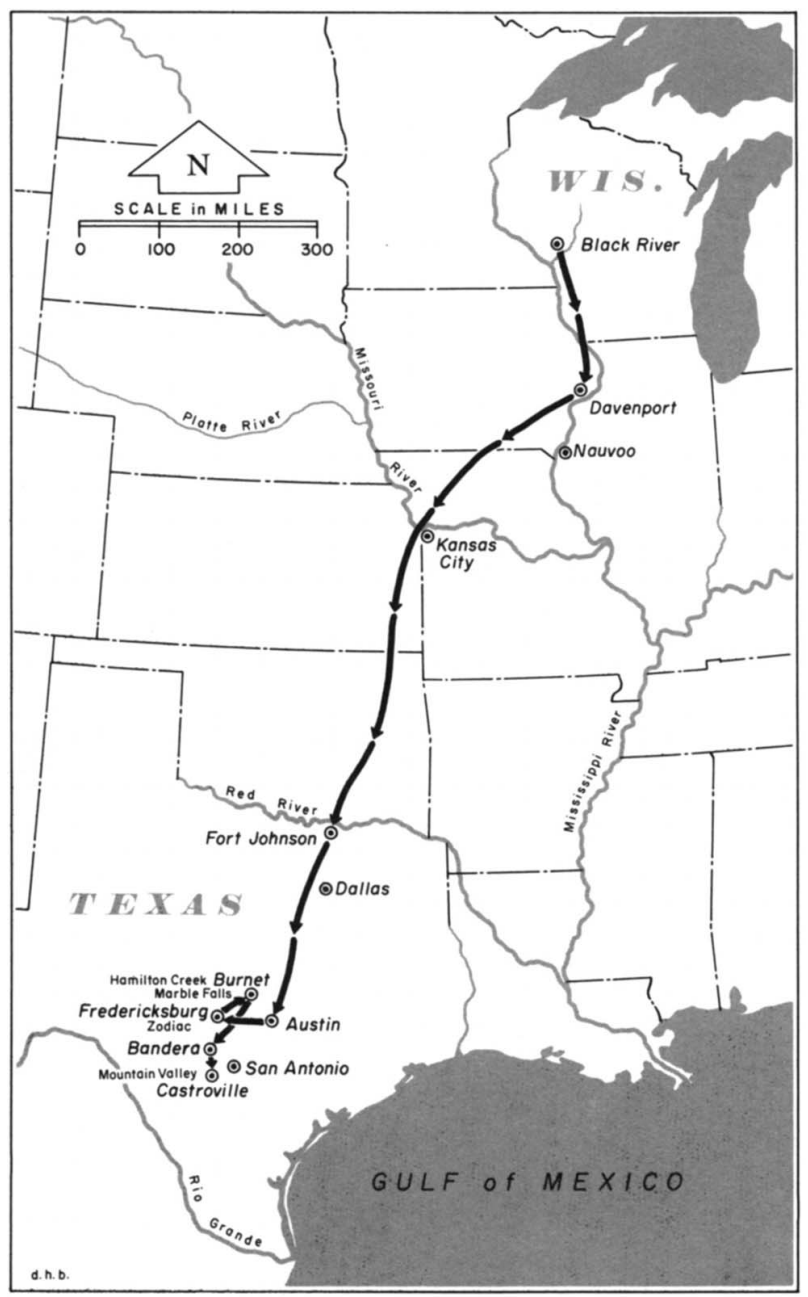

Figure 31. Route and locations of the Wight Colony in Texas, 1845-1858 by Davis Bitton (1969) any other he used for scrying (Quinn, 1998, pp. 246-247, Figure 10). The stone is smooth in texture with a hole through the center surrounded by eight smaller indentations of alternating sizes where the central flower and tuffs of the peyote button have been cored out. It is comparable to the eight-lobed peyote button in Figure 33. The coin-like ridged circular edge of Smith's stone not seen on the peyote button signifies the visionary nature of peyote. The alternating sizes

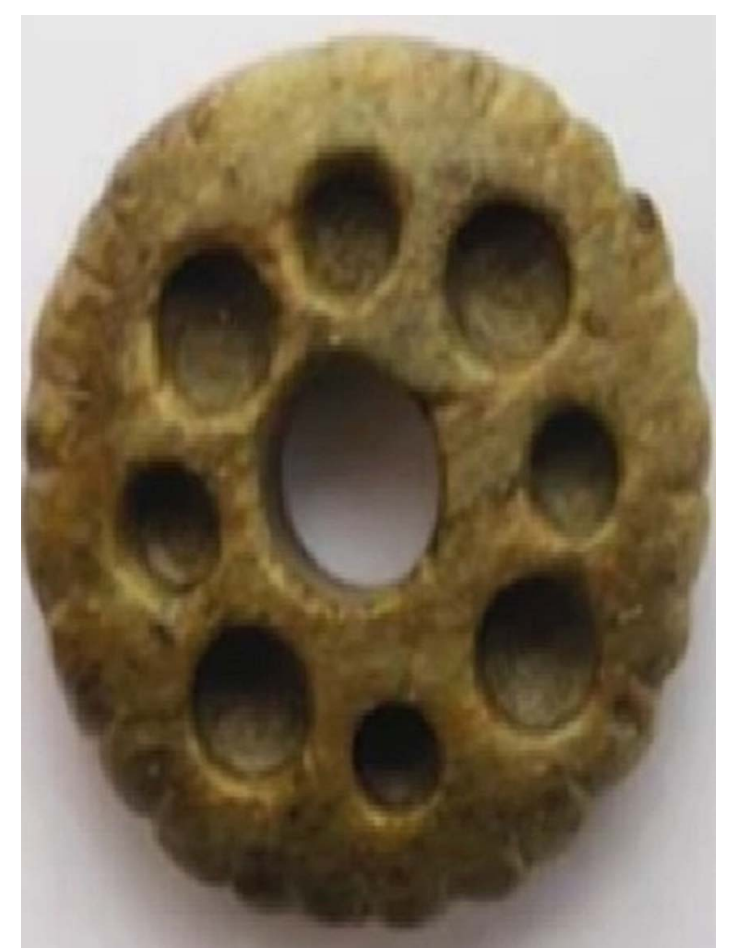

Figure 32. Joseph Smith's peyote stone (image from Quinn, 1998, Figure 10, colored version. Copyright: Signature Books)

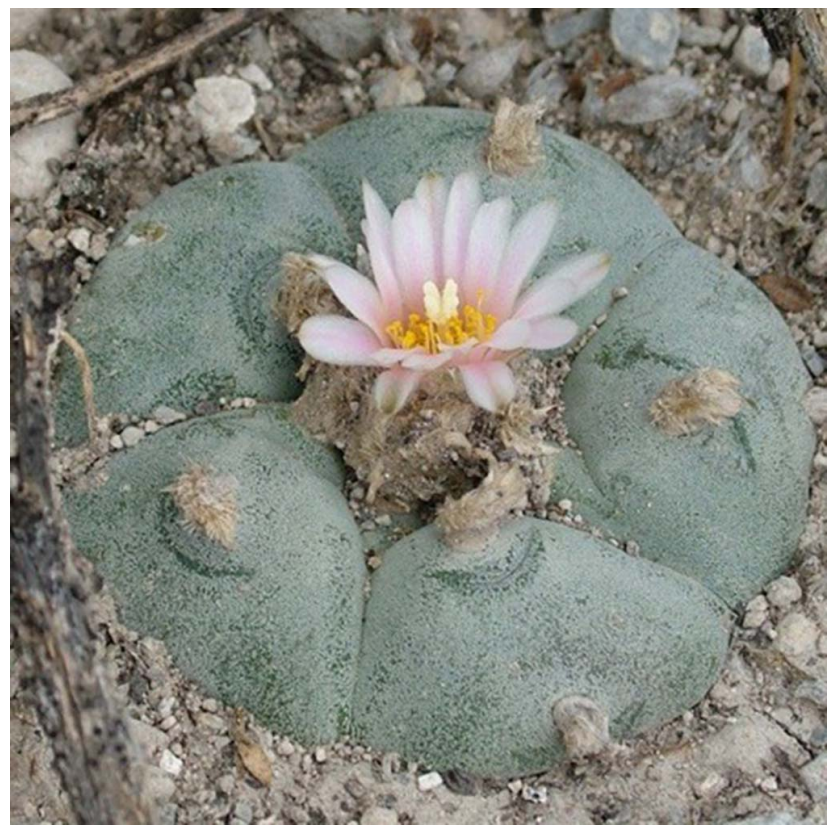

Figure 33. Eight-lobed peyote cactus reduced sized photo. Shutterstock 


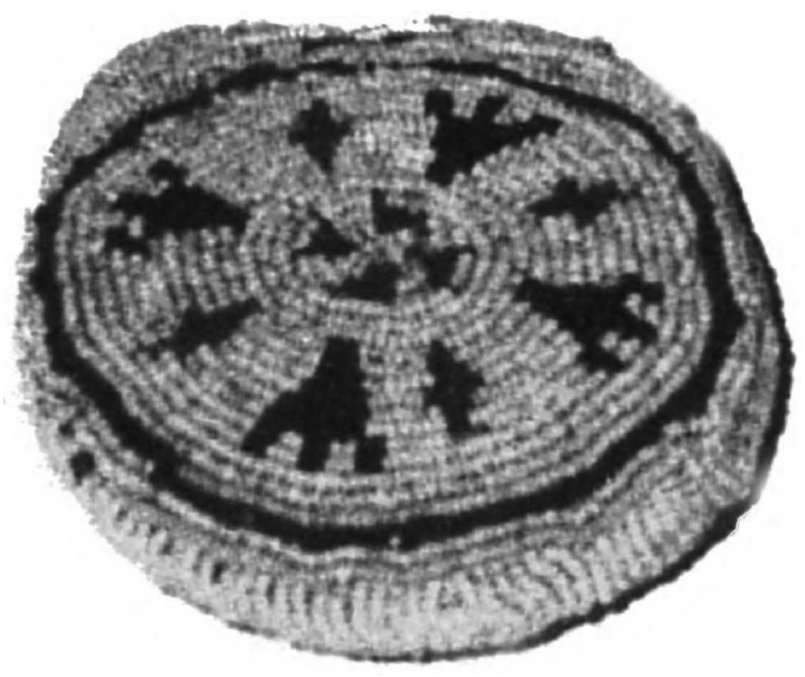

Figure 34. Eight-lobed peyote pouch (image from the Plains Indian Museum in Cody, Wyoming)

of the indentations on this stone are somewhat similar to the peyote button and are comparable to the alternating size of the tufts in Figure 33, an eight-lobed Plains Indian peyote pouch (Figure 34) currently displayed in the Plains Indian Museum in Cody, Wyoming (see Hultkrantz, 1997, p. 6).

The nomadic aboriginal peoples of the American Plains included the Lipan Apache, Tonkawa, Comanche, Kiowa, Otto, Osage, Arapaho, Sioux, and Pawnee, bordered on the northeast by the Ojibway, Potawatomi, Sauk, and Fox. Most of these groups were relocated, westward into Plains Indian territory following the Indian Removal Act of 1830 and interacted with Joseph Smith (Walker, 1993, pp. 6-7). For instance, by the $1840 \mathrm{~s}$, the Potawatomi had been resettled west of Nauvoo, Illinois, within the cultural boundaries of the Plains Indian groups, providing an opportunity for the transmission of information about peyote to Joseph Smith.

According to Omer Steward (1974), "The Lipan Apache Indians in the vicinity of Laredo, 1760 to 1850 s, learned of the properties of Peyote and the ritual for its use from Coahuiltecan-speaking Carrizo and Tonkawa and in turn taught Peyotism to the Comanche and Kiowa" (p. 211), their northern allies by 1830 (p. 215). A possible route for the spread of peyotism toward the northeast from Texas proposed by Steward (pp. 215-216) and included in the report by R. A. Smith (1961) states, "The demand for Mexican livestock, captives, and plunder increased after American commissioners made treaties of amity and trade with the Indians of the South Plains in the 1830s. The Comanche and Kiowa consequently stepped up their predatory raids below the Rio Grande ... Their deepest penetrations of Mexico put the Indians at points a thousand miles straight south of their home range in Kansas and Oklahoma ... One can suspect the warriors might also have learned about and experimented with the little spineless cactus, peyote, which grew in the area."

The intricate patterning on Joseph Smith's peyote stone in Figure 32 above may be a Native American stone gorget such as the stone in Figure 35 belonging to David Whitmer

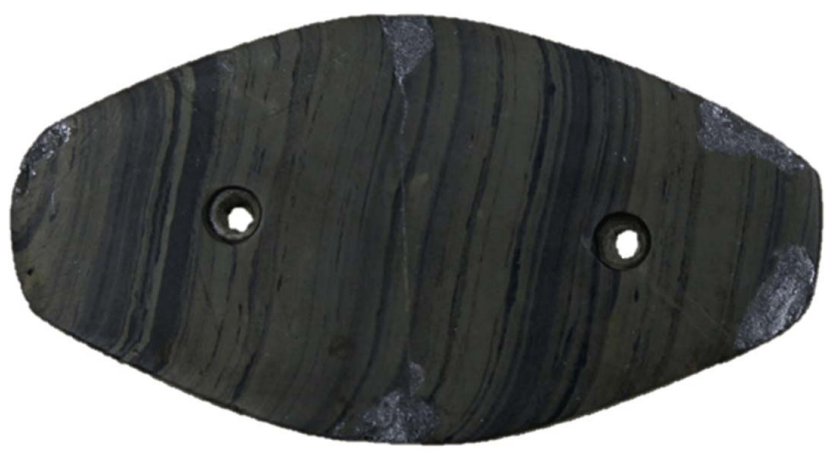

Figure 35. Gorget seers stone belonging to David Whitmer (courtesy: Signature Books)

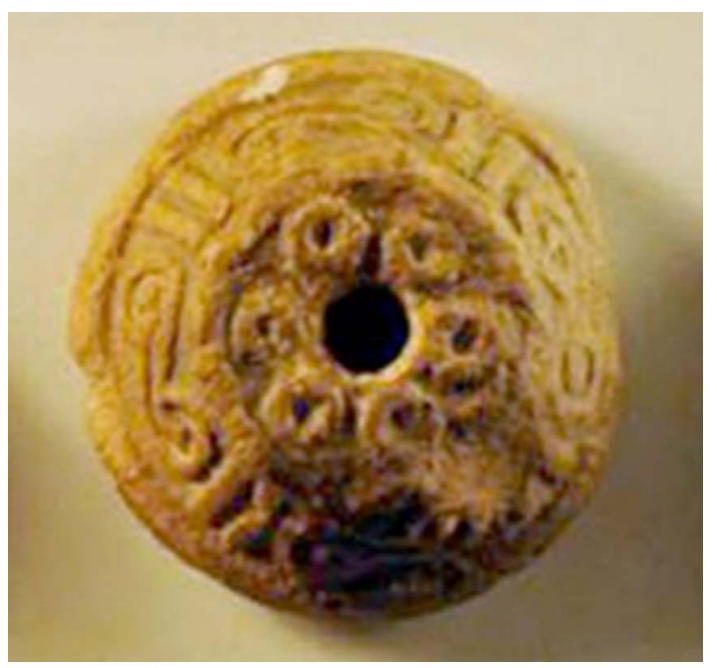

Figure 36. Pre-Columbian Aztec stone spindle whorl (photo by Christophe Helmke)

one of the three witnesses to the angel and golden plate and used as a seer stone. Native American gorgets, worn around the neck as signs of goodwill or an indication of status, and Smith's peyote stone, although of Native American origin, is not typical of a Native American gorget. Instead, it is similar to the pre-Columbian stone whorl from Mixtec, Mexico, shown in Figure 36. Joseph Smith's stone appears to be a Native American visionary peyote stone effigy. Similarly made pre-Columbian visionary stone effigies appear to represent the I. alvarus toad in Figures 35 and 36. Further, the Native Americans of the Lower Pecos region of southwest Texas have a history of ritual peyote use and the manufacture peyote effigies extending back 5,000 years (Powell, 2017; Terry et al., 2006).

Peyote has tufts of "hair" on each of its lobes and a central flower that if removed, leave a corresponding number of depressions. Native art, such as the peyote pouch in Figure 31 depicts peyote by the several circular depressions or tufts, often five or eight, surrounding a central circle or hole. The representation can further be stylized in native art by showing the tufts or depressions as alternating in size around the button as in Figure 32. An examination of Joseph Smith's stone shows precisely this same stylization. The stone consists of a central circle 
surrounded by eight circular depressions arranged in an alternating pattern of large-small-large.

Joseph Smith's peyote stone in Figure 32 above bears a striking resemblance to Figures 37-39 (frames from a video produced by DiezyMedia in 2007). In Figure 37, the transfixed, partially transformed shaman is holding a smooth-edged cactus, but in Figure 38, the shaman's eye is wide open, and reflecting a partial transformed eightlobed peyote button that had five lobes in Figure 37. In Figure 39, the consumed peyote button has further undergone entheogenic transformation amidst "spiritual light" pouring from its scalloped edges. In comparison, a reduced image of Joseph Smith's peyote in Figure 40 favorably compares to the visionary portrayal of the Huichol peyote button reflected in the shamans eye in Figure 41. Figure 41 shows the shaman in spirit and endowed with new powers.

While ownership of the peyote stone transferred to his heirs after his death, how this curious stone came to Joseph

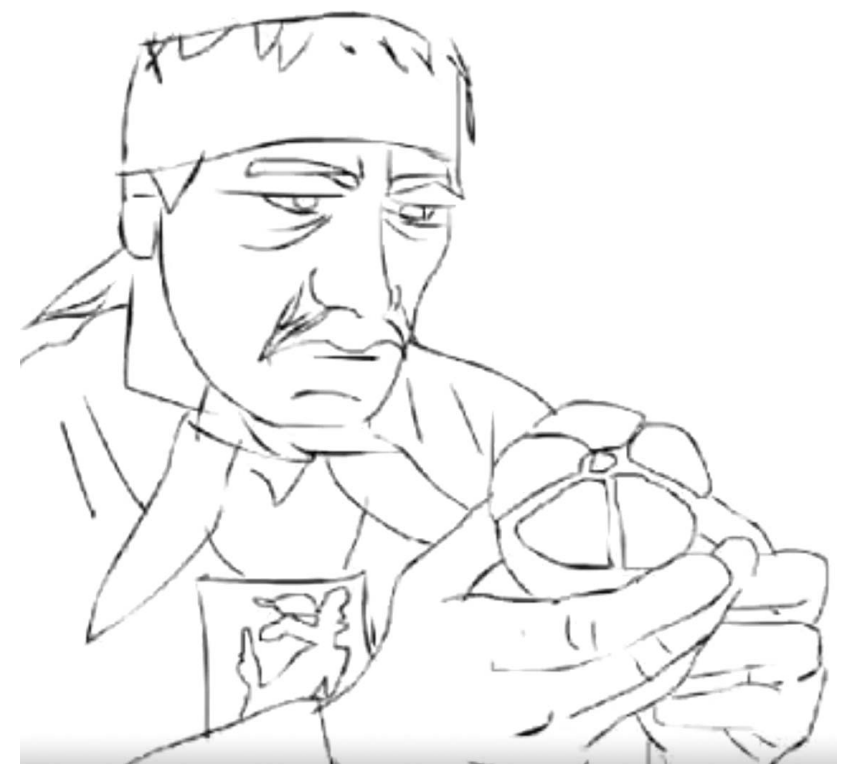

Figure 37. Huichol shaman transfixed as he looks on a five-lobe peyote cactus. DiezyMedia (2007)

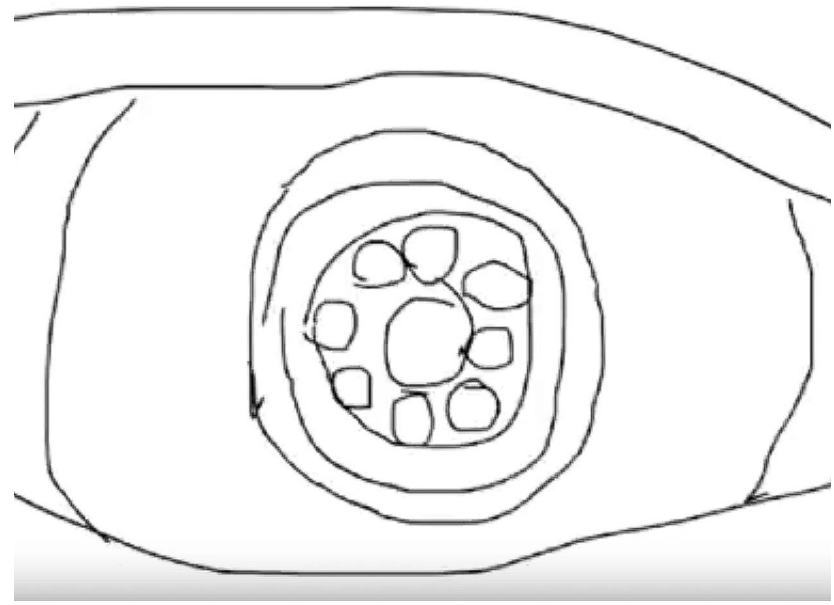

Figure 38. Partially transformed five to eight-lobed button is reflected in shaman's eye. DiezyMedia (2007)
Smith is unknown. Quinn (1998, pp. 246-247) speculated this stone, which was one of the seer stones Brigham Young had mentioned Joseph finding at Nauvoo on the banks of the Mississippi. However, considering the information above, it is likely a tooled stone that was handtooled by a Native American familiar with peyote. Joseph Smith owned other hand-tooled Native American stones used for divination, as other early Mormons did, each one tooled by a Native American (Quinn, 1998, p. 247).

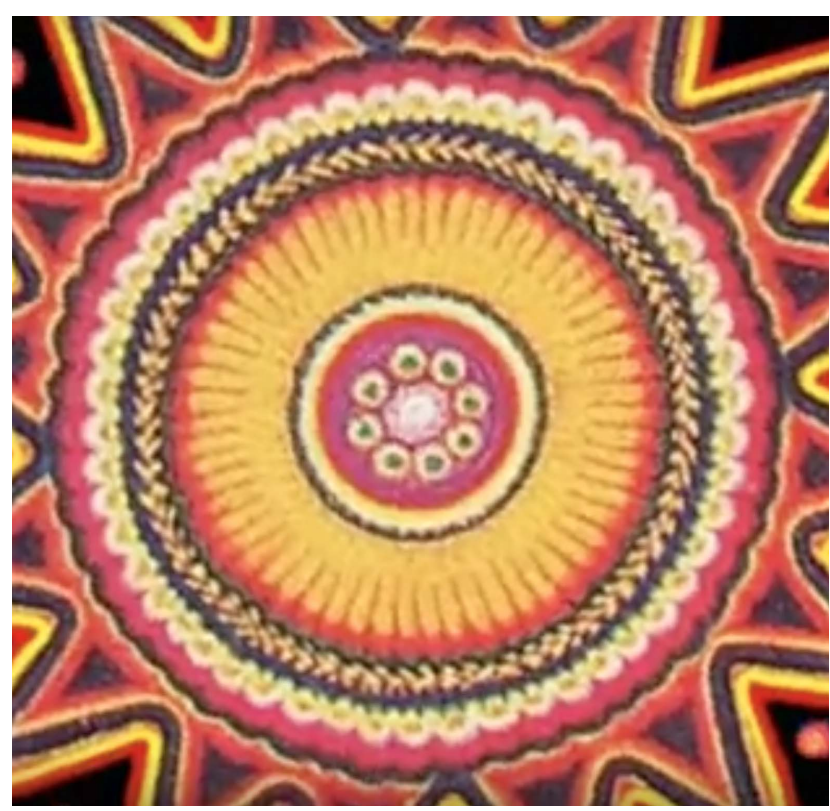

Figure 39. Fully transformed eight-lobed peyote button appears illuminating a new world. DiezyMedia (2007)

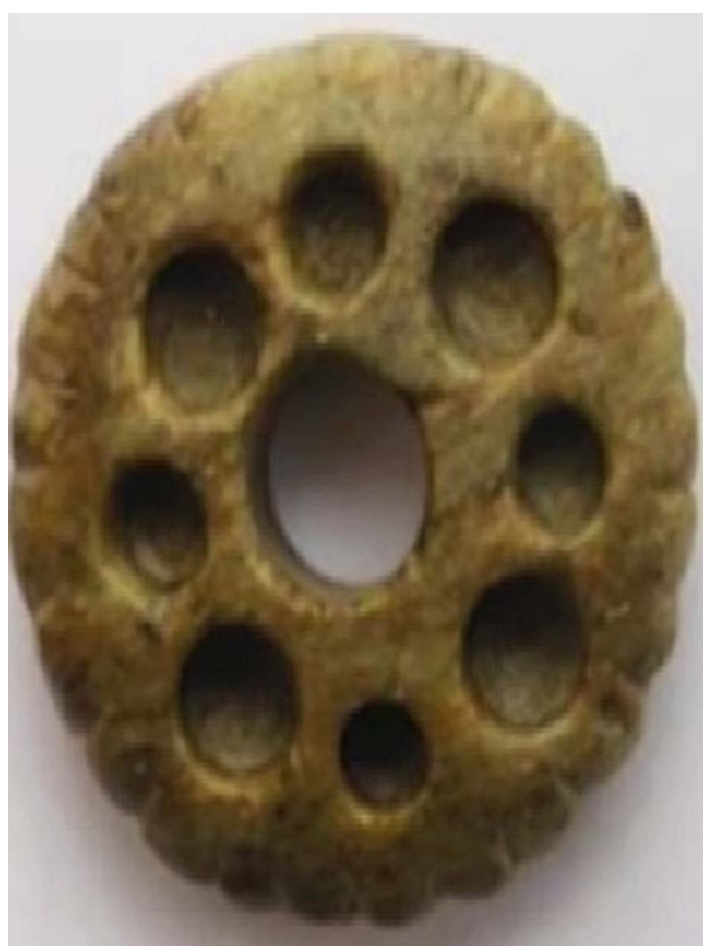

Figure 40. Joseph Smith's visionary peyote stone reduced in size for comparison (adapted from Figure 35) 


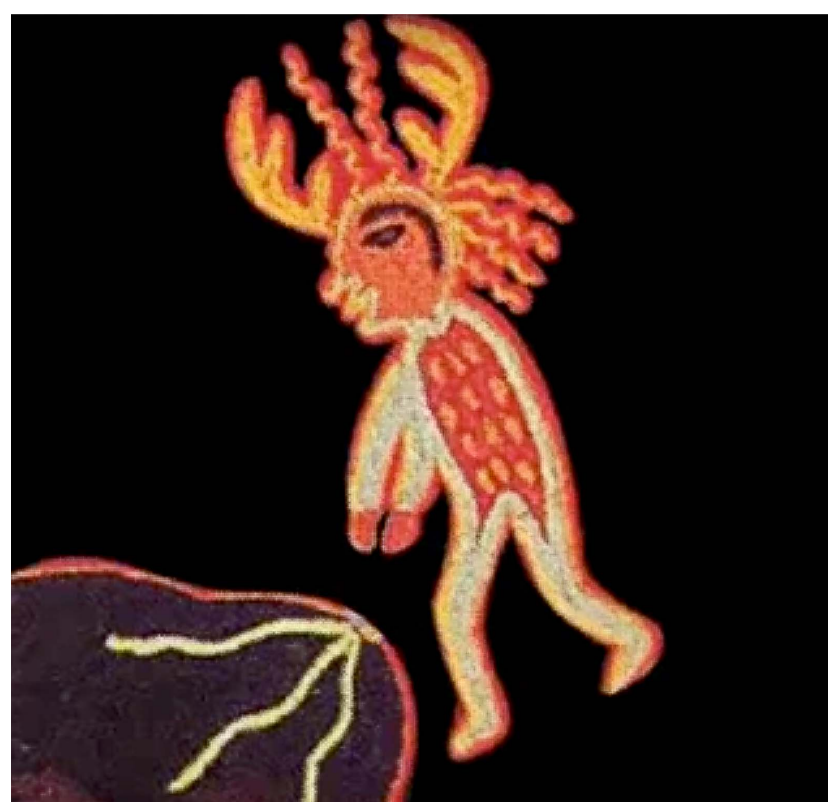

Figure 41. Huichol shaman in vision with new powers. DiezyMedia (2007)

For instance, the Whitmer family, followers of Joseph Smith from the 1820s, used two hand-tooled Native American gorgets with holes bored into them as seer stones (Quinn, 1998, Figures 11-13). Further, research conducted on these stones by Mormon scholars aside from Quinn has uniformly identified them as tooled by Native Americans (Ashurst-McGee, 2000, p. 165; Murphy \& Baca, 2016, p. 707). The peyote stone broadly resembles Native American gorgets but has a more intricate representation carved into it, and compares well to Native American representation of peyote.

\section{Lyman Wight, Mission to Texas}

Joseph Smith's vision was for Mormon colonies to span the globe, with Independence, Missouri being the western hub a worldwide kingdom of God, Jerusalem being the eastern hub. After the Mormon War of 1838, Smith moved the center of the kingdom to Nauvoo, Illinois along with his converts; simultaneously, he attempted to establish colonies adjacent to Indian territory in areas such as California, Oregon, Minnesota, the Great Basin, and Texas (The Joseph Smith Papers, 1842-1844, pp. 55, 170, fns 46-47). The purposes of these colonies were twofold: (a) expand the Kingdom of God until it filled the earth and (b) provide a place where, if another Moron War were to break out, the Mormons could find protection.

How did Joseph Smith acquire a peyote stone? Given that peyote was grown at the Texas-Mexican border, and Joseph Smith sent a scouting-and-negotiating team to south Texas to establish a Mormon-Indian colony on the Rio Grande, it represents one of two possible modes by which the peyote stone traveled from the hands of a peyotist in Texas to those of Joseph Smith in Nauvoo, Illinois. In 1844, Smith sent a Mormon expedition to persuade Sam Huston to allot lands then disputed by the Texans and the Mexicans. These lands included the entire Neueces strip (Figure 30) extending from
Corpus Christi down the gulf coast to Brownsville, then westward between the Rio Neueces and the Rio Grande Rivers encompassing the northern reaches of peyote inhabitation.

Just weeks after the Texas expedition party's return, Smith tasked Lyman Wight to establish a Texas colony, gave him a seer stone, and told him he would need this stone to receive revelation pertaining to his colonization work (Johnson, 2006, pp. 30-31). The stone Smith gave Wight was a seer stone, but not the peyote stone he retained until his death.

With the single exception of giving Oliver Cowdery his brown seer stone in 1829 , Smith is not reported to have given anyone else such a stone until he gave this one to Wight in April 1844. This unique action on Smith's part and its timing are both readily explainable if the negotiating party delivered the peyote stone to Smith in Nauvoo.

Also noteworthy is that Joseph Smith gave Lyman Wight not just any seer stone but specifically a white stone. We have noted above that the "white stone" has a place in Joseph Smith's biography, biblical interpretation, and theology. Drawing on Jesus' promise in Revelation 2:17 ("KJV"), the young Joseph Smith had searched for a "white stone" to use in scrying. This biblical promise of receiving a "white stone" also included the promise of receiving "the hidden manna to eat," a promised gift that appears to have materialized for Smith as A. muscaria mushrooms or datura in the family's "sacred grove."

Since Smith's own experience of becoming a seer included obtaining a "white stone" used to find entheogenic "hidden manna," Smith's bestowal to Wight would have been only a halfway-boon had he stopped there. Joseph Smith's instructions to Lyman Wight on how to be a seer on the same pattern as Smith would have included instructions on using "hidden manna" as an entheogen to facilitate Wight's experience of second sight.

Some researchers have concluded that the "manna" in Judeo-Christian scripture was a psychoactive variously identified as a water-soluble extract of ergot (Merkur, 2000 ) and the $A$. muscaria mushroom, also known to some as the white stone. (Allegro, 1970; Irvin, 2009). Such a reading was known in early Christianity judging by the number of works of art featuring the A. muscaria and psilocybin-containing mushroom (Brown \& Brown, 2016; Merkur, 2014; Rush, 2011). Joseph Smith, if he had not learned it from a mentor, had his own experience with entheogens, which would have led him conclude that entheogens were used in Judeo-Christian religion. It would be reasonable to believe that Joseph Smith would want to transmit his entheogenic knowledge to a trusted friend who had successfully ingested entheogens. Lyman Wight had responded well to the administration of an entheogen in 1831 when he "turned white" and "saw the Savior" (Hancock, 1858, p. 90) and remained a loyal friend to Joseph Smith even after Smith's death. It seems apparent that Wight's experience and loyalty resulted in Smith's gift of a white stone to locate entheogens in Texas. Apparently successful, Wight would have visions of Smith himself, years after the latter's death (Blythe, 2014; see also Johnson, 2006). Wight could easily carry 20,000 peyote buttons weighing 60 pounds to Joseph Smith in Nauvoo. 


\section{THE END OF VISIONARY MORMONISM}

The end of visionary and ecstatic Mormon can be causally associated with the death of Joseph Smith. Only a few of the many Mormon schisms that successors organized proved to be visionary. Those are visionary Mormon-Native American syncretisms that use peyote as an entheogen. Only one of Smith's descendants is reported to have used entheogens to facilitate spiritual growth and wished to introduce it as a general form of religious worship.

\section{Death of Joseph Smith}

Friction between Mormonism and their Missouri neighbors increased to the breaking point, and war broke out with Joseph Smith barely escaping with his life and the body of Mormons moving north in Illinois (Baugh, 2000). After fleeing Missouri, Smith established a new city that he called Nauvoo, the Beautiful along the eastern banks of the Mississippi River. Anticipating continued contention with non-Mormons, Smith formed a theocracy with political and military branches (Hansen, 1960, 1967). After Mormons deserters published an inflammatory first issue of the Nauvoo Expositor, Joseph Smith as the mayor of Nauvoo and general of the Nauvoo Legion ordered the destruction of the press.

\section{Schismatic Mormonism}

Within a century following the death of Joseph Smith, Mormonism splintered into over 200 schisms that collectively boast worldwide membership of over 16 million. The largest Mormon denominations are The Church of Jesus Christ of Latter-day Saints, The Community of Christ (formerly the Reorganized Church of Jesus Christ of Latter Day Saints), and groups collectively called Fundamentalist Mormons who still practice polygamy (Shields, 1982).

The leaders of these schisms each claim to be the legitimate heir to Joseph Smith, and prophet leader of their only true Church. Each schism attempts to maintain Mormonism as it was under Joseph Smith's leadership, including teaching his doctrine, believing his revelations, build temples, and performing his ordinances. For instance, in 1846, Brigham Young conducted temple endowments in the Nauvoo temple, as he understood Joseph Smith intended, including oil anointing, and raisins plucked from an Edenic tree (Buerger, 2001). However, to the disappointment of many, no religious visions or spiritual ecstasies were reported.

\section{Return of the Egyptian Papyri}

In winter 1846 as Brigham Young led the first contingent of Mormon's westward out of Illinois and across the Mississippi River and into Iowa where they camped. While there, a Potawatomi Captain inexplicably presented Brigham Young with "two sheets of the Book of Abraham [papyri]; also, a letter from their 'Father' Joseph Smith, dated 1843, and a map of their land by W.W. Phelps" (Todd, 1968, p. 40). Had Joseph Smith arranged for the Potawatomi captain to deliver peyote to Nauvoo and exchanged a peyote stone for Egyptian papyri as a token of their bargain, then the return of the papyri following Smith death solves the mystery.

\section{Successors' negative views of visionary symptomology}

Joseph Smith told early converts to expect somatologyassociated religious visions and spiritual ecstasies. To prepare converts for the entheogen-facilitated spiritual manifestations and associated symptomology, Joseph Smith (1839, pp. 18-19) explained:

It is more powerful in expanding the mind, enlightening the understanding, and storing the intellect with present knowledge, of a man who is of the literal seed of Abraham, than one that is a Gentile though it may not have half as much visual effect upon his body; for as the Holy Ghost falls upon one of the literal seed of Abraham, it is calm and serene; and his whole soul and body are only exercised by the pure spirit of intelligence; while the effect of the Holy Ghost upon a Gentile, is to purge out the old blood, and make him actually of the seed of Abraham. That man that has none of the blood of Abraham (naturally) must have a new creation by the Holy Ghost.

Therefore, stark was the difference between the many visions reported in early Mormonism and lack of similar reported after Joseph Smith's death, which distressed members inquired of their leaders. Mormon Apostle George A. Smith responded to these concerns in an 1867 discourse in Salt Lake City:

The question has often arisen among us, why it is that we do not see more angels, have more visions, [and] do not see greater and more manifestations of power? (Smith, 1867 , p. 10)

What followed is revealing. Apostle Smith recalled that in 1836, a filled Kirtland temple with over four hundred men of the priesthood, most of whom witnessed,

great manifestations of power, such as speaking in tongues, seeing visions, administration of angels. Many individuals bore testimony that they saw angels, and David Whitmer bore testimony that, he saw three angels passing up the south aisle, and there came a shock on the house like the sound of a mighty rushing wind, and almost every man in the house arose, and hundreds of them were speaking in tongues, prophesying or declaring visions, almost with one voice. (Ibid)

Then, Apostle Smith diminished the value of these experiences when he noted that,

A number of them who manifested the greatest gifts, and had the greatest manifestations have fallen out by the way side, you look around among us and they are not here .... But where you find men who have turned away, and have got terribly afflicted with self-conceit, you will find those, who, on that occasion and similar occasions, received great and powerful manifestations, and when 
the spirit came on them it seemed to distort the countenance, and caused them to make tremendous efforts in some instances. (Ibid)

Reflected in George A.'s next remarks is the post-Joseph Smith Mormon attitude regarding public religious manifestations and spiritual ecstasies. Speaking favorably of nonvisionary post-Smith "revelation" by inspiration, George A. spoke of faithful converts,

who received the knowledge of the things of God by the power of his spirit, and sought not after signs and wonders, and when the spirit rested upon them seemed to produce no visible demonstration. (Ibid)

George A. Smith knew there was a significant change in convert's visionary and ecstatic experience following the death of Joseph Smith. Direct and personal experience with angels and God gave way to revelation described as inspirational manifestations. As discussed above, in every case involving entheogen use in early Mormonism, a change in mental and emotional state was apparent to non-intoxicated observers both inside and outside the Church. That cessation of observable symptomology associated with post-Joseph Smith spiritual experience and the lack of visions and ecstasies reported by his successors provide persuasive evidence that Joseph Smith made use of entheogens. Even more noticeable are the many contemporary reports of entheogen-facilitated visions and ecstasies echoing those of Joseph Smith and early of Mormon converts.

The cessation of convert and leadership visionary and ecstatic experience following the death of Joseph Smith may partly inform the observation of Sterling Professor of Humanities at Yale University, Harold Bloom (2007) when he observed, "I am puzzled by the current Salt Lake City hierarchy. If there is any spiritual continuity between [Joseph] Smith and Gordon B. Hinckley [a Prophet and Utah successor to Joseph Smith], I am unable to see it. No disrespect is intended by that observation." If "placebo sacraments" replaced those infused with entheogens in early Mormonism, the spiritual discontinuity between Joseph Smith and his successors noted by Hard Bloom is readily accounted for and easily explainable.

\section{ENTHEOGENIC SUCCESSORS}

More than any other American religion, Mormonism has spawned several forays into entheogenic sacraments. We start with Joseph Smith's grandson, Frederick G. Smith.

\section{Frederick M. Smith}

The evidence reviewed above that Joseph Smith kept a Native American peyote stone as a sacred possession, attempted to locate a colony in peyote country, and intended to offer his followers peyote in the temple to facilitate their experience of God puts us in a better position to now to address a question we raised early in the paper. Like his grandfather Joseph Smith, Frederick M. Smith (1875-1946) manifested a precocious openness to entheogens, particularly peyote. As shown by Emma's letters and oral transmission of information to her children and grandchildren about the entheogenic-potent herbs jimson (datura) and lobelia, information about entheogens was passed on from Joseph Smith Jr's generation not through his Church but within his family. Joseph's family was also heirs to his hand-tooled seer stone in a peyote button. After his death, the stone remained in possession of his widow Emma, who passed it on to her second husband, Lewis Bidamon. The stone eventually came into the possession of Lewis's illegitimate son Charles Bidamon.

Frederick G. Smith, born in 1874, is likely to have seen the stone as a child and would have known it by reputation at the least. As the stone passed beyond the Smith family and eventually to collector Wilford C. Wood, any oral lore passed along with the stone within the Smith family failed to be transmitted with it further, and the stone was known only as one of Joseph Smith's seer stones, with no other information about its provenance or significance. However, just because the stone's representational significance was unknown to those who later sold and bought, it does not mean this significance was unknown to the Smith family.

Joseph Smith family's cross-generational legacy of a peyote stone and oral traditions about entheogenic herbs, and possibly about the stone itself, makes it unsurprising that Frederick M. Smith would have been exceptionally open to using entheogens, including peyote. Joseph Smith's revelations were the "bed-rock" of Mormonism and Frederick "wanted to understand the [revelatory] process," a subject he explored in The Higher Powers of Man (1918), with an entire chapter devoted "to the wonders of peyote" (Tommasini, 1997, p. 83). In this work, Frederick discussed the usefulness of peyote as an aid to spiritual development, reverberating his previous entheogenic experiences, experiences "he did not dare to chronicle" (Tommasini, 1997, p. 83). Frederick wrote, "Ecstasy has played an important role in human affairs, particularly the religious, and it is scarcely stating the matter fairly to hold that it is always associated with the pathological. Ecstasy is the central experience of religious experience usually associated with mysticism" (Smith, 1918).

Frederick learned "the rituals and powers of peyote" while pursuing his $\mathrm{PhD}$ in psychology. When Frederick visited Texas on vacation, "he observed Native American Indians who ate [peyote] ... [and] Catholic converts, who [drank it as a tea] for communion" (Tommasini, 1997, p. 83). Frederick believed the use of peyote in a spiritual setting was not a violation either of the spirit or the letter of his grandfather, Joseph Smith's 1833 dietary revelation known as the "word of wisdom" (Smith, 1833, pp. 207-208). "Frederick did not believe that peyote was technically, a drug. To him it was a natural substance, an ancient means to tap one's inner power derived from hallucinogenic cactus [as Frederick put it, is] "neither injurious nor habit-forming"' (Tommasini, 1997, p. 83).

Frederick introduced peyote to Virgil Tomson (18961989), an American composer who played a significant role in creating an "American Sound" in classical music. Smith gave Virgil "five bumpy little buttons less than an inch across and hard as wood and suggested that he chew them up before he went to bed" (Ibid). Virgil described his experience: "The effect, full visions complete in color and 
texture as a stage set, began slowly to appear before my closed or open eyes. Then came more rapidly ... Each one, moreover, had a meaning [and] could have been published with a title; and their symbolisms or subjects ... constituted a view of life not only picturesque and vast, but just as clearly all mine and all true" (Tommasini, 1997, p. 84).

Virgil introduced S. Foster Damon, an academic and poet specializing in the mystic William Black, and "who reported on the similarity of Blake's art to Peyote visions" (Piper, 2016). Frederick, Virgil, Damon, and others belonged to a "Harvard psychedelic circle" who were engaged in the exploration of peyote spirituality (Piper, 2016). Damon was profoundly affected by his peyote experiences and subsequently penned articles titled, The Evidence for Literal Transmutation and Symbols of Alchemy (Ibid). In Symbols of Alchemy, Damon (1922) argues that "To the alchemists, 'Gold,' the most perfect in the metalline world, stood for Man, the perfect product of creation" and to "to make gold,' actually meant to make (or materialize) a human being" (p. 79). Damon also discussed "The Elixir of Life" stating it was called such "because of the way it [by a chemical process] manifested itself ... since by its means, the afterworld could be reached." Further, "each alchemist used a new term [for the Elixir] every time he could think of one" (p. 81). Damon argued that Alchemists kept their secret by means of symbols and "frankly confessed that they deliberately confused their symbols" because it "was a matter of life and death for these men to keep their secret: one hint, and they with all their colleagues would have been massacred" (Ibid, 79, emphasis added). We have argued that Joseph Smith's intentionally obscured entheogen for the same reason.

Frederick Smith represents a rare confluence of many factors discussed in this paper. He was the patrilineal grandson of Joseph Smith, the prophet of the Reorganized Mormon church (1915-1946), a classically trained psychologist, and his doctoral thesis extensively discussed and advocated for using the entheogen peyote in religious settings. And if Frederick Smith's engagement with psychedelics and the "Harvard psychedelic circle" (Piper, 2016) reverberated in family traditions of his grandfather Joseph Smith's engagement with psychedelics, then Joseph Smith may himself have exerted an indirect but positive influence on the unfolding of psychedelic culture in the United States. One might think such was the case since the next "Harvard psychedelic circle" included Timothy Leary, Ram Dass, Huston Smith, and Andrew Weil who played a significant role ushering in a "New Age" for America (Lattin, 2011).

Contemporary scripture in the Community of Christ establishes Joseph Smith's original, historic goal of universal prophethood as one of the faith's immediate priorities. Revelations issued by Community of Christ prophet presidents Grant McMurray and Stephen Veazey and accepted by the Church into its Doctrine and Covenants (Community of Christ, 2007) who proclaim that participants in the Community of Christ are called "to be a prophetic people" and to "live prophetically" (Section 162:2c, 8c; 164:1). With its heritage of two early prophets who used and promoted entheogens as a potent means for living out this age-old vision, the Community of Christ is perhaps uniquely positioned among restorationist and liberal Christian denominations to leverage entheogens to become "a prophetic people" as Joseph Smith envisioned.

\section{Oto Church of the First-Born and the Native American Church (NAC)}

The Mormon-Indian-peyote syncretisms began in 1914 with the incorporation the Oto Church of the First-Born, the predecessor to the Native American Church (Rigal-Cellard, 1995). According to Weston La Barre (1938), early Plains Indian peyote "rites diffuse [ed] from the Kiowa-Comanche ... [to] the Oto Church of the First-born ... and its successor, the Native American Church." In their Churches, the Oto met to see the "faces of their dead relatives" and the Osage met "to see the face of Jesus" (Ibid).

The Oto Church of the First-born was found by Jonathan Koshiway (La Barre, 1938), the first Native American syncretism to seek legal incorporation. Koshiway was a missionary for the Reorganized Church of Jesus Christ of Latter Day Saint, now the Community of Christ and later "met with Kiowa and Arapaho to found the Native American Church" (Rigal-Cellard, 2004).

The Oto Church of the Firstborn likely represents Koshiway familiarity with the Mormon concept of the "Church of the Firstborn," and its visionary nature as described in Mormon scripture. Joseph Smith (1844) explained that Mormon's who were faithful and obtained the ordinances,

have the privilege of receiving the mysteries of the kingdom of heaven, to have the heavens opened unto them, to commune with the general assembly and Church of the Firstborn, and to enjoy the communion and presence of God the Father, and Jesus the mediator of the new covenant" (pp. 101-102; also see Collier, 1977).

Probably, Koshiway viewed peyote as the key to commune with the heavenly Church described by Joseph Smith.

\section{The Peyote Way Church of God}

The next Mormon-Native American-peyote syncretism, The Peyote Way Church of God (PWCG), was founded by Reverend Immanuel Pardeahtan Trujillo in 1979 and is based in Willcox, Arizona (Rigal-Cellard, 2004). In 1948, before founding the PWCG, Rev. Trujillo (50\% San Carlos Apache) joined the NAC. However, Trujillo became dissatisfied with the NAC because it limits membership and peyote sacrament to "genuine Natives" who can prove at least 25\% American Indian ancestry, and their spouses regardless of race. Trujillo's objection arose when, "William Russell, Apache Roadman for the NAC. Rev. Russell and Rev. Eugene Yoakum. .. [taught] Trujillo about the Spirit Walk and instilled in him the non-racist nature of the Holy Sacrament Peyote" (Peyote Way Church of God, n.d.).

Preferring not to limit peyote sacraments to Native Americans, Trujillo left the NAC in 1966. The PWCG "strictly adheres to the creeds of the L.D.S. Church" (Rigal-Cellard, 2004). According to Rigal-Cellard, "Anne 
Zapf, the President of the Church from 1985 to 1993, became a Mormon while in college and helped Trujillo settle the Church and ... a fairly high number of Natives of the region belong to the L.D.S. Church" (Ibid). Shields (1982, p. 221) goes further stating the PWCG descends from Joseph Smith's Mormonism. The PWCG believes that Joseph Smith's "Word of Wisdom" (D\&C 89) provides for their peyote sacrament (Murphy, 1994a, 1994b). Furthermore, the bylaws of the PWCG published in 1981 permit it to: "To grow, obtain, steward, protect and defend the Holy Psychedelic Sacrament of Peyote and its religious use; and to regulate the distribution of this Holy Psychedelic Sacrament to other members of this and other churches that use a psychedelic as their Holy Sacrament."

In its mission to offer peyote sacraments to non-Native Americans, the PWCG ran into legal difficulties. In 1991, one leader, Brother Bill Stites, was arrested by federal officers for felony possession of peyote found in his car (Rigal-Cellard, 2004). The legal challenges to the NAC offering peyote sacraments to non-Native Americans faced by the PWCG would bleed into the legal woes of the next Mormon-Native American-peyote syncretism, the Oklevueha NAC (ONAC).

\section{James Warren "Flaming Eagle" Mooney}

James Warren Mooney, a former Mormon, is the founder of the controversial ONAC that openly provides peyote ceremonies for people without Native American descent. Mooney reports being told in 1988 by Oklevueha Chief and Medicine Woman Little Dove he was a descendant of both Osceola, the Seminole Indian chief, and the famed ethnologist James Mooney (1861-1921); these genealogical attributions would become a center of controversy.

James Warren Mooney, then a Mormon and successful businessman, was given to understand that he was called to carry Native American plant medicine to non-Indians, the particulars of which he was instructed to decide for himself (L. B. Buford, personal communication, May 6, 2019). In 1994, after a lengthy period of training with various Native American medicine people including Guadalupe Rio de la Cruz, a Huichol Medicine woman, Mooney, conducted NAC peyote sacrament ceremonies without regard to race. In 1997, Mooney founded the ONAC and in 2000 was excommunicated from the Church of Jesus Christ of Latterday Saints.

In 2001, Mooney's home and new Church was raided by local law enforcement officials. In these places of worship, according to Mooney, they seized peyote amounting to over thirty pounds, representing about 10,000 dried peyote buttons. Mooney and his wife, arraigned on charges of "a dozen counts of drug trafficking and one count of racketeering," faced life in prison (Gehrke, 2001). The State of Utah contended that Mooney was not covered by the Federal Religious Peyote Exemption (21 C.F.R. $§ ~ 1307.3$ ) because he was not of Native American descent, nor a member of a federally recognized tribe. The trial resulted in James' and his wife Linda's conviction on multiple felony counts related to what was alleged to be a criminal enterprise based on distributing peyote within the context of their religious services. In 2003, the Mooney's appealed the trial court's decision to the Utah Supreme Court who: "Reverse [d] the trial court's decision... the federal regulation does not restrict the exemption to members of federally recognized tribes. We therefore rule that the exemption is available to all members of the Native American Church" (State of Utah, 2004).

Following this decision, the Utah District Attorney attempted to convince the federal government to prosecute James and Linda on similar charges related to peyote sacrament. The question in the government's case against James Mooney was his claimed Native American descent. Unexpectedly, government-certified genetic testing revealed Mooney's ethnicity: 58\% European, 35\% Native American, and 9\% Sub-Saharan African. (Certificate of Ancestry, 2005). After 6 months of investigation by United States Federal Attorneys and Federal Investigators, the case against James Mooney resolved when the Mooneys entered into a plea agreement. In conversation with one of the authors, Mooney believes that ONAC worldwide membership top well over 10,000 .

\section{CONCLUSIONS}

In this paper, we have reviewed the historical and psychopharmacological data that Joseph Smith employed entheogens in religious ordinances, facilitating many early Mormon visions and ecstasies. Gaining proficiency over time, Smith dealt with troublesome entheogen-related symptomology and "difficult trips" by encoding them, along with entheogenic visions and ecstasies, in his published teachings and revelations. The reproduction of biblical prophetic and apostolic experience and the antidepressant effects of entheogens in early Mormonism contributes to an understanding of Joseph Smith's charisma and the spectacular rise of his Church - it continues to do so if only in story. If organized religion is to relevant in our post-modern, Internet-informed, and ecopsychologically sensitive world, it must come to grips with what cognitive and neuroscience have to say about religious experience as natural phenomena and entheogens as near-universal facilitators of that experience.

Acknowledgements: The authors would like to thank Cindy Winkelman for her work in completing and formatting references, and Michael Winkelman for his tireless assistance and mentoring. They would also like to thank historian Don Bradley who provided extensive research on Joseph Smith's first vision, possible origins of the peyote stone, activities as an herbalist, and entheogenic Freemasonry; and his son Don Bradley Jr. who offered insight into Joseph Smith Sr.'s possible identification of entheogens with the Bible's "forbidden fruit" and "tree of life." They would also like to acknowledge the vast amount of historical data covering the Joseph Smith period that has been published as electronic transcriptions and photocopies of original documents by the Church of Jesus Christ of Latter-day Saints and the historical documents published by the Community of Christ. To their credit, these two Churches have placed on the Internet, both appealing and troublesome aspects of their foundation, making the combined collection 
an invaluable resource to researchers in religious studies. Collectively, these publications are well situated to provide valuable insights into religions with visionary and ecstatic origins, and whose historical data is relatively sparse.

Conflict of interest: The authors have no conflicting interest in writing and publishing this paper.

\section{REFERENCES}

Adams, V. M. (2013). Joseph Smith's boyhood surgery: Mercy during a "desperate siege." The Ensign of the Church of Jesus Christ of Latter-Day Saints, 43(6), 66-69. Retrieved from https:// www.churchofjesuschrist.org/study/ensign/2013/06/joseph-smithsboyhood-surgery-mercy-during-a-desperate-siege?lang=eng

Agrippa, H. C. (1801). The magus, or celestial intelligencer; being a complete system of occult philosophy, in three books. London, UK: Lackington, Allen, and Co.

Albanese, C. L. (2005). Nature religion in the United States. In B. Taylor (Ed.), Encyclopedia of religion and nature (Vol. 2, pp. 1175-1185). London, UK: Continuum.

Alizadeh, A., Moshiri, M., Alizadeh, J., \& Balali-Mood, M. (2014). Black henbane and its toxicity: A descriptive review. Avicenna Journal of Phytomedicine, 4(5), 297-311. doi:10.22038/ ajp. 2014.3187

Allegro, J. M. (1970). The sacred mushroom and the cross: A study of the nature and origins of Christianity within the fertility cults of the ancient Near East. New York, NY: Doubleday \& Co.

Allen, J. W., Gartz, J., Molter, D., \& Sihanonth, P. (2009). Psilocybe ovoideocystidiata: A new bluing species (Agricales) from Ohio, Pennsylvania and West Virginia. Ethnomycological Journals: Sacred Mushrooms Studies, 12, 75-86. Retrieved from https:// www.researchgate.net/publication/235436020_The_Occurrence_ Cultivation_and_Chemistry_of_Psilocybe_ovoideocystidiata_a new_Bluing_Species_Agaricales_from_Ohio_Pennsylvania_and West_VirginiaByAllen_John_W_Gartz_Jochen_Molter_Dan_ and_Prakitsin_Sih

Alrashedy, N. A., \& Molina, J. (2016). The ethnobotany of psychoactive plant use: A phylogenetic perspective. PeerJ, 4, e2546. doi:10.7717/peerj.2546

Anderson, D. S. (2018). Salt Lake School of the prophets, 1867-1883. Salt Lake City, UT: Signature Books.

Anderson, K. R. (1996). Joseph Smith's Kirtland: Eyewitness accounts. Salt Lake City, UT: Deseret Book Company.

Anderson, K. R. (2012). The Savior in Kirtland: Personal accounts of divine manifestations. Salt Lake City, UT: Deseret Book.

Anderson, L. F. (Ed.). (2001). Lucy's book: A critical edition of Lucy Mack Smith's family memoir. Salt Lake City, UT: Signature Books.

Anon. (1811). Communications relative to the Datura Stramonium, or Thorn-Apple as a cure or relief of asthma (p. 86). London, UK: Richard Phillips.

Anon. (1929, July 26). Doctor of olden days used herb remedies. Geneva Daily Times, New York, p. 6. Retrieved from http://www. fullerconsideration.com/images/Geneva_NY_Daily-Luman.png

Appanoose-Biography. (n.d.). Joseph Smith papers. Retrieved from https://www.josephsmithpapers.org/person/appanoose? highlight=Appanoose
Ashe, T. (1808). Travels in America performed in 1806. London, UK: William Sawyer \& Co.

Ashurst-McGee, M. R. (2000). A pathway to prophethood: Joseph Smith Junior as rodsman, village seer, and Judeo-Christian prophet (MA thesis). Utah State University, Logan, UT. Retrieved from https://digitalcommons.usu.edu/cgi/viewcontent. cgi?article $=7976 \&$ context $=$ etd

Bailey, R. T. (1952). Emma Hale: Wife of the Prophet Joseph Smith (MS thesis). Brigham Young University, Provo, UT. Retrieved from https://scholarsarchive.byu.edu/cgi/viewcontent. cgi?article $=5493 \&$ context $=$ etd

Banks, C. S. (1945). The Mormon Migration into Texas. The Southwestern Historical Quarterly, 49(2), 233-244. Retrieved from https://www.jstor.org/stable/30237238

Barrett, F. (1801). The magus, or celestial intelligencer: Being a complete system of occult philosophy. London, UK: Lackington, Allen, \& Co. Retrieved from https://archive.org/details/ b22006795/page/n16

Barsuglia, J., Davis, A. K., Palmer, R., Lancelotta, R., WindhamHerman, A. M., Peterson, K., \& Griffiths, R. R. (2018). Intensity of mystical experiences occasioned by 5-MeO-DMT and comparison with a prior Psilocybin study. Frontiers in Psychology, 9(2459), 1-6. doi:10.3389/fpsyg.2018.02459

Bassett, B. (2016). Newton County: Another time, another place. The Newcomer, 22(1), 9-15. Retrieved from http://ingenweb. org/innewton/newcomer/Winter\%202016\%20digital.pdf

Bauer, F. (1838). On ergot of rye. Transactions of the Linnean Society of London, 8, 475-482. doi:10.1111/j.1095-8339. 1838.tb00195.x

Baugh, A. (2000). A call to arms: The 1838 Mormon defense of Northern Missouri, dissertations in Latter-day Saint history. Provo, UT: Joseph Fielding Smith Institute for Latter-day Saint History and BYU Studies

Benich, J. J., \& Carek, J. (2011). Evaluation of the patient with chronic cough. American Family Physician, 84(8), 887-892. Retrieved from aafp.org/afp/2011/1015/p887.html

Bennett, C. (2018). Liber 420: Cannabis, magickal herbs and the occult. Walterville, OR: Trine Day.

Berlant, S. R. (2005). The entheomycological origin of Egyptian crowns and the esoteric underpinnings of Egyptian religion. Journal of Ethnopharmacology, 102(2), 275-288. doi:10.1016/j.jep.2005.07.028

Bernard, D. (1829). Light on Masonry: A collection of all the most important documents on the subject of speculative Free Masonry. Utica, NY: William Williams. Retrieved from http:// hdl.handle.net/2027/hvd.32044024149429

Beug, M. W., Shaw, M., \& Cochran, K. W. (2006). Thirty-plus years of mushroom poisoning: Summary of the approximately 2, 000 reports in the NAMA case registry. McIlvainea, 16(2), 47-68. Retrieved from https://namyco.org/docs/Poisonings30year.pdf

Bidamon (Smith), E. (1867). Emma Smith Bidamon letter to Joseph Smith III. Community of Christ Archives.

Bigelow, J. (1817). American medical botany of the native medicinal plants of the United States. U.S. Commission of fish and fisheries (Vol. 1). Boston, MA: Cummings and Hilliard.

Bitton, D. (1969). Mormons in Texas: The Ill-Fated Lyman Wight Colony. 1844-1858. Arizona and the West, 11(1), 5-26. Retrieved from https://www.jstor.org/stable/40167489

Bloom, H. (2007). Perspectivism and Joseph Smith. Sunstone Magazine, 145, 18-19. Retrieved from https://www. sunstonemagazine.com/pdf/145-18-19.pdf 
Blythe, C. J. (2014). "Would to God, brethren, I could tell you who I am!': Nineteenth-Century Mormonisms and the Apotheosis of Joseph Smith. Nova Religio: The Journal of Alternative and Emergent Religions, 18(2), 5-27. doi:10.1525/nr.2014.18.2.5

Bradley, D. (2010). Acquiring an all-Seeing eye: Joseph Smith's first vision as seer initiation and ritual apotheosis. Unpublished Manuscript copy in possession of author RB.

Bradley, D. (2019, August, 7). Joseph Smith's First Vision as Endowment and Epitome of the Gospel of Jesus Christ. Paper presented at Fair Conference Proceedings, Salt Lake City, UT.

Bradshaw, J. M. (2015). Freemasonry and the origins of modern temple ordinances. Interpreter: A Journal of Mormon Scripture, 15, 159-237. Retrieved from https://journal.interpreterfoundation. org/freemasonry-and-the-origins-of-modern-temple-ordinances/

Breslaw, E. G. (1996). Tituba: Reluctant witch of Salem, devilish Indians and Puritan fantasies. New York, NY: New York University Press.

Brooke, J. L. (1996). The refiner's fire: The making of Mormon cosmology, 1644-1844. Cambridge, UK: Cambridge University Press.

Brown, J. B., \& Brown, J. M. (2016). The psychedelic gospels: The secret history of hallucinogens in Christianity. Rochester, VT: Park Street Press.

Bruhn, J. G., De Smet, A., El-Seedi, H. R., \& Beck, O. (2002). Mescaline use for 5700 years. The Lancet, 359(9320), 1866. doi:10.1016/S0140-6736(02)08701-9

Bryson, D. (1996). Comprehensive review in toxicology for emergency clinicians. Washington, DC: Taylor \& Francis.

Buerger, D. J. (2001). The development of the Mormon temple endowment ceremony. Dialogue: A Journal of Mormon Thought, 34(1-2), 75-122. Retrieved from https://www. dialoguejournal.com/wp-content/uploads/sbi/articles/Dialogue_ V34N0102_87.pdf

Bunker, G. L., \& Bitton, D. (1975). Mesmerism and Mormonism. Brigham Young University Studies, 15(2), 146-170. Retrieved from https://scholarsarchive.byu.edu/cgi/viewcontent.cgi?article= $1677 \&$ context=byusq

Burkhart, K. K. (2004). The anticholinergic patient. In R. C. Dart (Ed.), Medical toxicology (3rd ed., pp. 51-54). Philadelphia, PA: Lippincott.

Bushman, R. L. (2005). Joseph Smith: Rough stone rolling. New York, NY: Alfred A. Knopf.

Bushman, R. W. (2006). The first vision as out-of-body experience and what that means about the first vision (rev.). Washington, DC: Sunstone Symposium.

Busia, K., \& Heckels, F. (2006). Jimsonweed: History, perceptions, traditional uses, and potential therapeutic benefits of the genus Datura. HerbalGram the Quarterly Journal of the American Botanical Council, 69, 40-50. Retrieved from http://cms. herbalgram.org/herbalgram/issue69/article2930.html?ts=156548 788\&signature $=88 \mathrm{ddb} 192 \mathrm{~b} 08 \mathrm{c} 91 \mathrm{fb} 3 \mathrm{e} 874470 \mathrm{ed} 6340 \mathrm{be}$

Byron, R. M. (1993). Joseph Smith and the Lamanites. In S. E. Black \& C. D. Tate, Jr. (Eds.), Joseph Smith: The prophet, the man (pp. 187-202). Provo, UT: Religious Studies Center, Brigham Young University.

Cahill, J. (2003). Updates in emergency medicine. New York, NY: Springer.

Caporael, L. R. (1976). Ergotism: The Satan loosed in Salem? Science, 192(4234), 21-26. doi:10.1126/science.769159

Carney, S. A. (n.d.). Guns along the Rio Grande: Palo Alto and Resaca de la Palma: In the U. S. Army Campaigns of the
Mexican War. Retrieved from https://history.army.mil/ brochures/Resaca de la Palma/Palo Alto.htm

Carter, A. J. (1996). Narcosis and nightshade. British Medical Journal, 313(7072), 1630-1632. doi:10.1136/bmj.313.7072.1630

Casey, E., \& Gutierrez, C. (2005). From Eleusis to America: Masonry and the modern mysteries. In C. Gutierrez (Ed.), The "occult" in nineteenth-century America (pp. 215-244). Aurora, CO: The Davies Group.

Caswell, H. (1843). The prophet of the nineteenth century. London, UK: J.G.F. \& J. Rivington.

Certificate of Ancestry. (2005). Test sample no. S070309. Salt Lake City, UT: DNA Print Genomics. Blood drawn under the supervision of federal law enforcement. Copy in possession of the author signed by James Sorenson, Laboratory Supervisor.

Clark, D. L. (1997-1998). The Mormons of the Wisconsin Territory: 1835-1848. Brigham Young University Studies Quarterly, 37(2), 57-85. Retrieved from https://scholarsarchive.byu.edu/ cgi/viewcontent.cgi?article $=3213$ \& context; $=$ byusq

Cole, A. (1831, February 28). Gold Bible, No. 5. Palmyra, NY: The Reflector. Retrieved from http://www.sidneyrigdon.com/ dbroadhu/NY/wayn1830.htm

Collier, F. C. (1977). The Church of the firstborn and the holy order of God. Doctrine of the Priesthood (Vol. 1, p. 4). Salt Lake City, UT: Collier's Publishing Co.

Communications. (1811). Communications relative to the Datura Stramonium, or Thorn-Apple as a cure or relief of asthma. London, UK: Richard Phillips.

Community of Christ. (2007) Book of doctrine and covenants. Community of Christ. Independence, MO: Herald Publishing House.

Compton, T. (1997). In sacred loneliness: The plural wives of Joseph Smith. Salt Lake City, UT: Signature Books.

Converse, R. N. (1996). The Tremper Mound Pipes. Ohio Archaeologist, 46(1), 27-28. Retrieved from https://kb.osu.edu/ bitstream/handle/1811/55920/OHIO_ARCHAEOLOGIST_46_ 1_WINTER_1996.pdf?sequence=1\&isAllowed;=y

Copland, J., Darwall, J., \& Conolly, J. (1826). The London medical repository and review (Vol. 3). London, UK: Thomas and George Underwood.

Council of Fifty. (1844-1846). Record of the council of fifty or Kingdom of God, minutes and other records, 3 vols.; handwriting of William Clayton. Church History Library: Church of Jesus Christ of Latter-day Saints. Retrieved from https:// www.josephsmithpapers.org/paper-summary/council-of-fiftyminutes-march-1844-january-1846-volume-1-10-march-18441-march-1845/9\#source-note

Coxe, J. R. (1827). The American dispensatory (7th ed.). Philadelphia, PA: H. C. Carey \& I. Lea.

Crop Production Magazine. (2018, June). Ergot alkaloids under the spotlight. Retrieved from http://www.cpm-magazine.co.uk/ wp-content/uploads/2018/06/ErgotJun18.pdf

Curtis, L. (1892). Recollections of the prophet Joseph Smith. Juvenile Instructor, 27(12), 385-386. Retrieved from https://scottwoodward.org/josephsmith_miracles_raisingwilliam huntingtonfromdead.html

Dahl, L. E., \& Cannon, D. Q. (Eds.). (1997). Encyclopedia of Joseph Smith's teachings. Salt Lake City, UT: Bookcraft.

Damon, S. F. (1922). Symbols of alchemy. Occult Review, 36(2), 77-85. Retrieved from http://www.iapsop.com/archive/materials/ occult_review/occult_review_v36_n2_aug_1922.pdf 
Dannaway, F. R., Piper, A., \& Webster, P. (2006). Bread of heaven or wines of light: Entheogenic legacies and esoteric cosmologies. Journal of Psychoactive Drugs, 38(4), 493-503. doi: 10.1080/02791072.2006.10400588

Davis, A. K., So, S., Lancelotta, R., Barsuglia, J., \& Griffiths, R. R. (2018). The epidemiology of 5-methoxy-N, N-dimethyltryptamine (5-MeO-DMT) use: Benefits, consequences, patterns of use, subjective effects, and reasons for consumption. Journal of Psychopharmacology, 32(7), 779-792. doi:10.1177/0269881 118769063

deCypher. (2008, November 15). Re: Datura Stramonium and Cannabis Indica ... An unholy matrimony of blood, fire, and death. Retrieved from https://www.shroomery.org/forums/ showflat.php/Number/9482564

Dibble. (1892). Recollections of the prophet Joseph Smith. The Juvenile Instructor, 27(10), 303-304. Retrieved from https:// ia800503.us.archive.org/25/items/juvenileinstruct2710geor/ juvenileinstruct2710geor.pdf

DiezyMedia. (2007). Huichol, the Mystical Journey: An animation of a painting by Mariano Valadez Navarro. Found in Lozoya, X. (2003). The plants of the soul: Pre-hispanic hallucinogens. Mexican Archeology, 10(59), 58-63. Images from animation. Retrieved from https://www.youtube.com/watch? $\mathrm{v}=\mathrm{Tf} 4 \mathrm{H} 8 \mathrm{sS} 6 \mathrm{~F} 9 \mathrm{c}$

Dinger, S. C. (2016). The doctors in this region don't know much: Medicine and obstetrics in Mormon Nauvoo. Journal of Mormon History, 42(4), 51-68. doi:10.5406/jmormhist.42.4.0051

Doblin, R. (1991). Pahnke's "Good Friday experiment": A longterm follow-up and methodological critique. The Journal of Transpersonal Psychology, 23(1), 1-28. Retrieved from http:// www.atpweb.org/jtparchive/trps-23-91-01-001.pdf

Drevets, W. C., Zarate, C. A., \& Furey, M. L. (2013). Antidepressant effects of the muscarinic cholinergic receptor antagonist scopolamine: A review. Biological Psychiatry, 73(12), 1156-1163. doi:10.1016/j.biopsych.2012.09.031

Drug Enforcement Administration. (2013). Jimson weed (Datura stramonium). Retrieved from https:/www.deadiversion. usdoj.gov/drug_chem_info/jimson_w.pdf

Drummond, J. G. (2013). Mystery cults in Roman Britain (MA thesis). Southampton, UK: University of Southampton.

Dunn, S. C. (2002). Automaticity and the dictation of The Book of Mormon. In D. Vogel \& B. Metcalf (Eds.), American apocrypha: Essays on The Book of Mormon (pp. 17-46). Salt Lake City, UT: Signature Books.

Durham, R. C. (1974). Is there no help for the widow's son? Presented as the presidential address of the Mormon history association, Nauvoo, IL. Retrieved from https://archive.org/ stream/IsThereNoHelpForTheWidow/Is+There+No+Help+ For+The+Widow_djvu.txt

Ehat, A. F. (1994). 'Who shall ascend into the hill of the Lord?' Sesquicentennial reflections of a sacred day: 4 May 1842. In D. W. Parry (Ed.), Temples of the ancient world (Chapter 3). Salt Lake City, UT: Deseret.

Eliade, M. (1964). Shamanism: Archaic techniques of ecstasy. London, UK: Routledge \& Kegan Paul.

Ermacora, D. (2017). The comparative milk-suckling reptile. Anthropozoologica, 52(1), 59-81. doi:10.5252/az2017n1a6

Erying, H. (1989). The faith of a scientist. Salt Lake City, UT: Deseret Book.

Escohotado, A. (2012). The general history of drugs (p. 73). Valparaiso, Chile: Graffiti Militante Press.
Essential. (n.d.). The essential guide to Datura: (Jimsonweed, Devil's weed, Devil's trumpet, Moonflower, Toloache. Retrieved from https://thethirdwave.co/psychedelics/datura

Evens, Z. N., \& Stellpflug, S. J. (2012). Holiday plants with toxic misconceptions. Western Journal of Emergency Medicine, 13(6), 538-542. doi:10.5811/westjem.2012.8.12572

Ezdejini, A. (2016). Controversial A Vestan compounds relating to the fire cult. Theory and Practice in Language Studies, 6(10), 1996-2001. doi:10.17507/tpls.0610.15

Fillerup, R. (1996). Early Mormon vision \& near-death experiences (Revised from August 22, 1990 presentation). Salt Lake City, UT: Sunstone Symposium.

Folkard, R. (1884). Plant lore, legends, and lyrics: Embracing the myths, traditions, superstitions, and folk-lore of the plant kingdom (p. 566). London, UK: S. Low, Marston, Searle, and Rivington.

Foster, L. (2005). The psychology of prophetic charisma: New approaches to understanding Joseph Smith and the development of charismatic leadership. Dialogue: A Journal of Mormon Thought, 36(4), 1-14. Retrieved from https://www. dialoguejournal.com/wp-content/uploads/sbi/articles/Dialogue_ V36N04_21.pdf

Fuller, R. C. (2008). Spirituality in the flesh: Bodily sources of religious experience. Oxford, UK: Oxford University Press.

Gee, J. (2007). New light on the Joseph Smith papyri. FARMS Review, 19(2), 245-259. Retrieved from https://scholarsarchive. byu.edu/msr/vol19/iss $2 / 20$

Gehrke, R. (2001, January 9). Peyote pariah' faces legal, religion woes. Deseret News. Retrieved from https://www.deseretnews. com/article/818235/Peyote-pariah-faces-legal-religion-woes. html

Geraty, L. F. L. (2015). Berserk for Berserkir: Introducing combat trauma to the compendium of theories on the Norse Berserker. Reykjavík, Iceland: University of Iceland.

Goodman, J. (1993). Tobacco in history: The cultures of dependence. New York, NY: Routledge.

Griffiths, R. R. (2018). Intensity of mystical experiences occasioned by $5-\mathrm{MeO}-\mathrm{DMT}$ and comparison with a prior psilocybin study. Frontiers in Psychology, 9(2459), 1-6. doi:10.3389/ fpsyg.2018.02459

Griffiths, R. R., Hurwitz, E. S., Davis, A. K., Johnson, M. S., \& Jesse, R. (2019). Survey of subjective "God encounter experiences": Comparisons among naturally occurring and those occasioned by the classic psychedelics psilocybin, LSD, ayahuasca, or DMT. PLoS One, 23(4), e0214377. doi:10.1371/ journal.pone. 0214377

Griffiths, R. R., Richards, W. A., McCann, U., \& Jesse, R. (2006). Psilocybin can occasion mystical-type experiences having substantial, sustained personal meaning and spiritual significance. Psychopharmacology, 187(3), 268-283. doi:10.1007/ s00213-006-0457-5

Groesbeck, C. J. (1975). The archetypal image of the wounded healer. Journal of Analytical Psychology, 20(2), 122-145. doi:10.1111/j.1465-5922.1975.00122.x

Groesbeck, C. J. (1988). The Smiths and their dreams and visions: A psycho-historical study of the first Mormon family. Sunstone Magazine, 3, 22-29. Retrieved from https://www.sunstonemagazine.com/wp-content/uploads/sbi/articles/064-21-29.pdf

Groesbeck, C. J. (1989). C. G. Jung and the shaman's vision. Journal of Analytical Psychology, 34(3), 255-275. doi:10.1111/j.14655922.1989.00255.x 
Groesbeck, C. J. (1990). Audio recording retrieved from https:// www.sunstonemagazine.com/joseph-smith-and-the-translationof-the-book-of-mormon-a-huchol-indian-parallel/

Groesbeck, C. J. (2004). The Book of Mormon as symbolic history: A new perspective on its place in history and religion. Sunstone Magazine, 3, 35-45. Retrieved from https:// www.sunstonemagazine.com/wp-content/uploads/sbi/articles/ $131 \% 2035-45 . p d f$

Groesbeck, C. J. (2005). Joseph Smith and the shaman's vision: A forgotten paradigm for the life of the Mormon prophet. Salt Lake City, UT: Sunstone Symposium. Retrieved from https:// www.sunstonemagazine.com/joseph-smith-the-shamans-visiona-forgotten-paradigm-for-the-life-of-the-mormon-prophet/

Grow, M. J., Esplin, R. K., McGee, M. A., \& Mahas, J. D. (Ed.) (2016). Administrative records, Council of Fifty, Minutes, March 1844-January 1846, Matthew J. Grow edition. Salt Lake City, UT: Church Historian's Press.

Gunnison, J. W. (1852). The Mormons, or, Latter-Day Saints, in the Valley of The Great Salt Lake: A history of their rise and progress, peculiar doctrines, present conditions, and prospects. Philadelphia, PA: Lippincott, Grambo \& Co.

Guzman, G. (2009). The hallucinogenic mushrooms: diversity, traditions, use and abuse with special reference to the genus Psilocybe. In J. K. Misra \& S. K. Deshmukh (Eds.), Fungi from different environments (pp. 256-277). Enfield, NH: Science Publishers.

Guzmán, G., Gaines, R. V., \& Ramírez-Guillén, F. (2007). New species of hallucinogenic psilocybin in eastern U.S.A. International Journal of Medicinal Mushrooms, 9, 75-77. doi:10.1615/IntJMedMushr.v9.i1.90

Hagan, W. (1995). Quanah Parker, Comanche Chief. Norman, OK: University of Oklahoma Press.

Hajicek-Dobberstein, S. (1995). Soma siddhas and alchemical enlightenment: Psychedelic mushrooms in Buddhist tradition. Journal of Ethnopharmacology, 48(2), 99-118. doi:10.1016/ 0378-8741(95)01292-L

Hales, B. C., \& Hales, L. H. (2015). Joseph Smith's Polygamy: Toward a better understanding. Sandy, UT: Greg Kofford Books.

Haller, J. S., Jr. (2000). The people's doctors: Samuel Thomson and the American botanical movement, 1790-1860. Carbondale, IL: Southern Illinois University Press.

Hamby, E. B. (2004). The roots of healing: Archaeological and historical investigations of African-American herbal medicine (Unpublished doctoral dissertation). Tennessee Research and Creative Exchange, University of Tennessee, Knoxville, Tennessee. Retrieved from https://trace.tennessee.edu/utk_ graddiss/4543/

Hamel, B., \& Chiltoskey, M. U. (1975). Cherokee plants and their uses: A 400-year history. Sylva, NC: Herald Publishing Co.

Hammerson, G., \& Santos-Barrera, G. (2004). Incilius alvarius. The IUCN red list of threatened species. Retrieved from http://dx.doi.org/10.2305/IUCN.UK.2004.RLTS.T54567A111 52901.en

Hancock, L. (1858). Autobiography (1803-1836) copied from his own journal by Clara E. H. Lloyd, great-grand daughter. Retrieved from http://www.ourlittlecircle.com/journals/ lhancock.pdf

Hansen, K. (1960). The political kingdom of God as a cause for Mormon-Gentile conflict. Brigham Young University Studies, 2, 241-260. Retrieved from https://www.jstor.org/stable/ 43044910
Hansen, K. (1967). Quest for empire: The political kingdom of god and the council of fifty in Mormon history. East Lansing, MI: Michigan State University Press.

Harper, S. C. (2012). Joseph Smith's first vision: A guide to the historical accounts. Salt Lake City, UT: Deseret Book. Retrieved from https://history.churchofjesuschrist.org/article/firstvision-accounts-synthesis?lang=eng

Harper, S. C. (2016). The first vision, a narrative from Joseph Smith's own accounts. Retrieved from https://history. churchofjesuschrist.org/article/first-vision-accounts-synthesis? lang=eng.

Harris, W. (1841). Mormonism portrayed. Warsaw, Poland: Sharp \& Gamble.

Hartshorne, H. (1855). On the nature and treatment of cholera. In G. A. Wilson \& R. A. Lewis (Eds.), The stethoscope: Monthly journal of medicine and the collateral sciences (Vol. 5, pp. 438-440). Richmond, VA: Ritchie and Dunnavant.

Hedges, A. H., \& Smith, A. D. (2010). Joseph Smith, John C. Bennett, and the extradition attempt. In R. N. Holzapfel \& K. Jackson (Eds.), Joseph Smith, the Prophet and Seer (pp. 437-466). Provo, UT: Religious Studies Center, Brigham Young University.

Heinerman, J. (1975). Joseph Smith and herbal medicine: A brief study of the botanical arts in Mormonism. Manti, UT: Mountain Valley Publishers.

Heinrich, C. (2002). Magic mushrooms in religion and alchemy. Rochester, VT: Park Street Press.

Holstege, P., \& Borek, H. A. (2012). Toxidromes. Critical Care Clinics, 28(4), 479-498. doi:10.1016/j.ccc.2012.07.008

Howard, J. (1962). Potawatomi mescalism and its relationship to the diffusion of the peyote cult. Plains Anthropologist, 7(16), 125-135. doi:10.1080/2052546.1962.11908289

Howe, E. D. (1834). Mormonism unvailed or, a faithful account of that singular imposition and delusion, the Golden Bible. Painesville, NY: E. D. Howe.

Howlett, D. J. (2014). Kirtland temple: The biography of a shared Mormon sacred space. Urbana, IL: University of Illinois Press.

Hoyt, H. (1933). One hundred years of land values in Chicago (p. 50). Chicago, IL: University of Chicago Press.

Hultkrantz, A. (1997). The attraction of Peyote: An inquiry into the basic conditions for the diffusion of the Peyote religion in North America. Stockholm, Sweden: Stockholm University Press.

Hyde, J. (1857). Mormonism: Its leaders and designs (2nd ed.). New York, NY: W. Petridge \& Company.

Irvin, J. R. (2009). The holy mushroom: Evidence of mushrooms in Judeo-Christianity. Crestline, CA: Gnostic Media Research \& Publishing.

Jacobs, D. (1996). The use of datura in rites of transition. In M. Winkelman \& W. Andritzky (Eds.), Sacred plants, consciousness and healing: A cross-cultural and interdisciplinary perspectives yearbook of cross-cultural medicine and psychotherapy (pp. 341-351). Berlin, Germany: Verlag.

Jensen, M. K. (2012). Rest of the story: Latter-day Saint relations with Utah's Native Americans. Mormon Historical Studies, 12(2), 17-25. Retrieved from http://mormonhistoricsites.org/ wp-content/uploads/2013/03/The-Rest-of-the-Story-Latter-daySaint-Relations-with-Utah\%E2\%80\%99s-Native-Americans.pdf

Johnson, M. C. (2006). Polygamy on the Pedernales. Lyman Wight's Mormon Villages in Antebellum Texas, 1845 to 1858. Logan, UT: Utah State University Press. 
Jonasson, M., \& Afshari, R. (2016). Chronicle of datura toxicity in 18th and 19th century. Asia Pacific Journal of Medical Toxicology, 5(4), 101-106. doi:10.22038/apjmt.2016.8134

Joseph Smith Papers. (1844-1845). Lucy Mack Smith, History, 18441845 (p. 10, bk. 3). Retrieved from https://www.josephsmithpapers.org/paper-summary/lucy-mack-smith-history-1844-1845/40

Kane, E. (1995). Artemisia Snow's account of Luman Walters. In E. W. Kane \& N. R. Bowen (Eds.), Gentile account of life in Utah's Dixie, 1872-73: Elizabeth Kane's St. George journal (pp. 1-16). Salt Lake City, UT: Tanner Trust Fund, University of Utah Library.

Keller, M. H., \& Kane, F. (1967). The use of hyoscyamine as a hallucinogen and intoxicant. American Journal of Psychiatry, 124(6), 852-854. doi:10.1176/ajp.124.6.852

Kirkham, F. W. (1959). A new witness for Christ in America (p. 401). Salt Lake City, UT: Utah Printing.

KnarkKorven. (2011, July 13). Stromata germinating on a sclerotium of $C$. purpurea. Retrieved from https://www. shroomery.org/forums/showflat.php/Number/-

Knight, C., \& Lomas, R. (1996). The Hiram Key: Pharaohs, Freemasons and the discovery of the secret scrolls. United Kingdom: Century Books.

La Barre, W. (1947). Primitive psychotherapy in Native American cultures: Peyotism and confession. The Journal of Abnormal and Social Psychology, 42(3), 294-309. doi:10.1037/ h0060765

La Barre, W. (1938). They Peyote Cult. New Haven, CT: Yale University Publications.

Langford, L. A., \& Bandera, J. W. (2003). Lyman Wight and his colony: A brief history. The Bandera County Historian, 24(3). Retrieved from https://www.banderacounty.org/historical/ HistorianFall2003.pdf

Larsen, C. M. (1992). By his own hand upon papyrus: A new look at the Joseph Smith papyri. Grand Rapids, MI: Institute for Religious Research.

Lattin, D. (2011). The Harvard Psychedelic Club: How Timothy Leary, Ram Dass, Huston Smith, and Andrew Weil killed the Fifties and ushered in a new age for America (Repr. Ed.). San Francisco, CA: HarperOne.

Le Garff, E., Delannoy, Y., Mesli, V., Hédouin, V., \& Tournel, G. (2016). Forensic features of a fatal datura poisoning case during a robbery. Forensic Science International, 261, e17-e21. doi:10.1016/j.forsciint.2016.02.028

Leary, T., Metzner, R., \& Alpert, R. (1964). The psychedelic experience: A manual based on the Tibetan Book of the Dead. New York: University Books.

Lee, M. R., Dukan, L., \& Milne, I. (2018). Amanita muscaria (fly agaric): From a shamanistic hallucinogen to the search for acetylcholine. Journal of the Royal College of Physicians of Edinburgh, 48(1), 85-91. doi:10.4997/JRCPE.2018.119

Lyttle, T., Goldstein, D., \& Gartz, J. (1996). Bufo toads and bufotenine: Fact and fiction surrounding an alleged psychedelic. Journal of Psychoactive Drugs, 28(3), 267-290. doi:10.1080/02791072.1996.10472488

Mahas, J. D. (2017). American Indians and the Nauvoo-era Council of Fifty. In M. J. Grow \& R. E. Smith (Eds.), The Council of Fifty: What the records reveal about Mormon history (p. 120). Provo, UT: Religious Studies Center, Brigham Young University.

Majić, T., Schmidt, T. T., \& Gallinat, J. (2015). Peak experiences and the afterglow phenomenon: When and how do therapeutic effects of hallucinogens depend on psychedelic experiences? Journal of Psychopharmacology, 29(3), 241-253. doi:10.1177/ 0269881114568040

Marquardt, H. M. (2002). Martin Harris: The Kirtland years, 1831-1870. Dialogue: A Journal of Mormon Thought, 35(3, Fall), 1-40. Retrieved from https://dialoguejournal. com/wp-content/uploads/sbi/articles/Dialogue_V35N03_9.pdf

Marshall, J. (1999). The elixir: An alchemical study of the ergot mushroom. The Australian Journal of Anthropology, 10(1), 118ff. Retrieved from https://link.gale.com/apps/doc/A55007541/ ITOF?u=marriottlibrary\&sid;=ITOF\&xid;=d006da05

Martin, K. L. (2006). Conjuring moments and other such hoodoo: African American women \& spirit work (Unpublished doctoral dissertation). Florida State University, Tallahassee, FL. Retrieved from https://fsu.digital.flvc.org/islandora/object/fsu: 180961/datastream/PDF/view

Mason, P. Q. (2015). Mormonism. Oxford research encyclopedia of religion. Oxford, UK: Oxford University Press. Retrieved from https://oxfordre.com/religion/view/10.1093/acrefore/ 9780199340378.001.0001/acrefore-9780199340378-e-75

McWhitney, B. (1888). Brother McWhitney. [Interview by Arthur B. Deming of McWhitney's friend Stephen H. Hart: Naked truths about Mormonism, (April), 2-3]. In L. Petersen (Ed.), Hearts made glad: The charges of intemperance against Joseph Smith the Mormon Prophet. Salt Lake City, UT: LaMar Petersen.

Merkur, D. (2000). The mystery of mana: The psychedelic sacrament of the Bible. Rochester, VT: Park Street Press.

Merkur, D. (2014). The hidden manna: The psychedelic sacrament in medieval Roman Catholicism. In J. H. Ellens (Ed.), Seeking the sacred with psychoactive substances: Chemical paths to spirituality and to God (pp. 157-180). Santa Barbara, CA: Praeger.

Meyers, C. F. (2011). The marketplace of Boston: Macrobotanical remains from Faneuil Hall (MA thesis). University of Massachusetts, Boston, MA. Retrieved from https://www. sunstonemagazine.com/wp-content/uploads/sbi/articles/06421-29.pdf

Mikaszewska-Sokolewicz, M. A., Pankowska, S., Janiak, M., Pruszczyk, P., Łazowski, T., \& Jankowski, K. (2016). Coma in the course of severe poisoning after consumption of red fly agaric (Amanita muscaria). Acta Biochimica Polonica, 63(1), 181-182. doi:10.18388/abp.2015_1170

Morain, W. D. (1998). The sword of Laban: Joseph Smith, Jr. and the dissociated mind. Washington, DC: American Psychiatric Press.

Morain, W. D. (2013). Joseph Smith - Fantasies and their origins. The John Whitmer Historical Association Journal, 33(1), 170-183. Retrieved from https://www.jstor.org/stable/43200319

Morgan, D. (2014). Dale Morgan on the Mormons: Collected works, part 2, 1949-1970. Norman, OK: University of Oklahoma Press.

Morgan, D. (n.d.). The Independent Gazetteer (Taunton, Massachusetts) reported on 11 January 1833. Retrieved from http:// www.sidneyrigdon.com/dbroadhu/NE/miscne01.htm

Morgan, G. R., \& Stewart, O. C. (1984). Peyote trade in South Texas. The Southwestern Historical Quarterly, 87(3), 269-296. Retrieved from https://www.jstor.org/stable/30239815

Mormons, the Mormon Bible. (1839). Cleveland Harold \& Gazette, Cleveland, Ohio. Retrieved from http://www.sidneyrigdon.com/ dbroadhu/oh/miscoh08.htm

Moss, J. J. (1878). Letter J. J. Moss to James T. Cobb dated Dec. 17, 1878. Original in A. T. Schroeder Collection, Wisconsin 
State Historical Society. Retrieved from http://www. solomonspalding.com/docs/Wil1878a.htm

Moss, J. J. (1913). Testimony of Moss, J. James in Open Court. In E. B. Bond, W. H. Kelley, \& A. B. Deming (Eds.), Public discussion of the issues between The Reorganized Church of Jesus Christ of Latter Day Saints and The Church of Christ [Disciples] (pp. 383-387). Marrickville, NSW: Wentworth Press.

Muller, L. J. (1998). Love potions and the ointment of witches: Historical aspects of the nightshade alkaloids. Clinical Toxicology, 36, 617-627. doi:10.3109/15563659809028060

Murphy, T. (1994a). Word of wisdom and peyote: The diversity of interpretations, part one. Sacred Record, 15(1), 3-6. Retrieved from https://ssrn.com/abstract=2246451

Murphy, T. (1994b). Word of wisdom and peyote: The diversity of interpretations, part two. Sacred Record, 15(2), 4-6. Retrieved from https://ssrn.com/abstract=2246463

Murphy, T., \& Baca, A. (2016). Rejecting racism in any form: Latter-day Saint rhetoric, religion, and repatriation. Open Theology, 2(1), 700-725. doi:10.1515/opth-2016-0054

Navet, E. (1988). The Ojibway and the fly Amanita (Amanita muscaria). For ethnomycology of North American Indians. Journal of the Society of Americanists, 74(1), 163-180. doi:10.3406/jsa.1988.1334

Neale, C., Camfield, D., Reay, J., Stough, C., \& Scholey, A. (2013). Cognitive effects of two nutraceuticals ginseng and bacopa benchmarked against modafinil: A review and comparison of effect sizes. British Journal of Clinical Pharmacology, 75(3), 728-737. doi:10.1111/bcp.12002

Nemu, D. (2019). Getting high with the host high: Entheogens in the Old Testament. Journal of Psychedelic Studies. Advance online publication. 1-16. doi:10.1556/2054.2019.004

Newell, L. K., \& Avery, V. T. (1994). Mormon enigma: Emma Hale Smith (2nd ed.). Urbana, IL: University of Illinois Press.

Newman, D. (2017). Alchemically stoned: The psychedelic secret of Freemasonry. Oklahoma City: The Laudable Pursuit.

Olaiz, H. (2014). The Kirtland temple as a shared space: A conversation with David J. Howlett. Dialogue: A Journal of Mormon Thought, 47(1), 104-123. Retrieved from https:// www.dialoguejournal.com/wp-content/uploads/sbi/articles/ Dialogue_V47N01_310.pdf

Olmstead, J. W. (2000). From Pentecost to administration: A reappraisal of the history of the Hosanna Shout. Mormon Historical Studies, 2(2), 7-37. Retrieved from http://mormonhistoricsites.org/wp-content/uploads/2013/05/ Mhs2.2OlmsteadFall2001.pdf

Omar, M. N. I. A., \& Foxworth, J. (2014). Using toxidromes to assess poisoned patients. Hospital Medicine Clinics, 3(1), e128-e138. doi:10.1016/j.ehmc.2013.09.001

Ostry, M. E., Anderson, N. A., \& O'Brien, J. G. (2010). Field guide to common macrofungi in eastern forests and their ecosystem functions (USDA Forest Service Northern Research Station General Technical Report, NRS-79). Delaware, OH: United States Forest Service. Retrieved from https://www.nrs. fs.fed.us/pubs/gtr/gtr_nrs79.pdf

Owens, L. S. (1999). Joseph Smith: America's hermetic prophet. In B. Waterman (Ed.), The prophet puzzle: Interpretive essays on Joseph Smith (pp. 155-171). Salt Lake City, UT: Signature Book.

Pahnke, W. N. (1963). Drugs and mysticism: An analysis of the relationship between psychedelic drugs and mystical consciousness ( $\mathrm{PhD}$ dissertation). Harvard University, Cambridge, MA.
Pahnke, W. N. (1966). Drugs and mysticism. International Journal of Parapsychology, 8, 295-313. Retrieved from https://pdfs. semanticscholar.org/5b11/fee8012402efb16d534d7ec45c0533 6902c0.pdf

Park, B. (2008). Rational supernaturalism: Early Mormonism and enlightened-romantic rhetoric. Library Research Grants, 25, 1-16. Retrieved from https://scholarsarchive.byu.edu/libraryrg studentpub/25

Pendell, D. (2005). PharmakoGnosis. San Francisco, CA: Mercury House.

Peschel, K. (1979). The legend of Miskwedo. Journal of Psychedelic Drugs, 11, 1-2. doi:10.1080/02791072.1979.10472089

Petersen, L. (1975). Hearts made glad: The charges of intemperance against Joseph Smith the Mormon Prophet. Salt Lake City, UT: LaMar Petersen.

Peyote Way Church of God. (n.d.). Detailed chronology of events in the history of the Peyote way Church of God. Retrieved from https://peyoteway.org/history/chronology.php

Pierson, T. (2011). Image of Colorado River toad. Retrieved from https://eol.org/media/8799933

Piper, A. (2016). A 1920's Harvard psychedelic circle with a Mormon connection; Peyote use amongst the Harvard aesthetics. In G. J. Llwydd (Ed.), The invisible college magazine [Electronic] (8th ed.). Amazon.com: CreateSpace Independent Publishing Platform. Retrieved from https://www. academia.edu/23387519/A_1920_s_Harvard_Psychedelic_ Circle_with_a_Mormon_Connection_Peyote_Use_amongst_ the_Harvard_Aesthetes

Porta, J. B. (1558). Natural magick. London, uk: John Wright.

Porter, M. (1826). On the surgical pathology of the larynx and trachea. In J. Copland, J. Darwall, \& J. Conolly (Eds.), The London medical repository and review (pp. 328-339). London, UK: Thomas and George Underwood.

Powell, E. A. (2017). Reading the White Shaman Mural. Archeology: A publication of the Archaeological Institute of America. Retrieved from https://www.archaeology.org/issues/274-1711/ features/5996-reading-the-white-shaman-mural

Pratt, O. (1840). A[n] Interesting Account of Several Remarkable Visions, 1840. The Joseph Smith Papers. Retrieved from https://www.josephsmithpapers.org/paper-summary/appendixorson-pratt-an-interesting-account-of-several-remarkable-visions$1840 / 7$

Purple, W. D. (1877, May 3). Joseph Smith, The originator of Mormonism. Historical reminiscences of the town of Afton. Chenango Union, 30(33), 3. Retrieved from https://www. josephsmithpapers.org/paper-summary/appendix-reminiscenceof-william-d-purple-28-april-1877-people-v-js/1\#full-transcript

Quinn, D. M. (1998). Early Mormonism and the magic world view (Revised and Enlarged). Salt Lake City, UT: Signature Books.

Remini, R. V. (2002). Joseph Smith. London, NY: Penguin Group.

Richards, W. (2016). Sacred knowledge: Psychedelics and religious experience. New York, NY: Columbia University Press.

Rigal-Cellard, B. (1995). The Peyote Way Church of God: Native Americans v. new religions v. the law. European Review of Native American Studies, 9(1), 35-43. Retrieved from http:// classiques.uqac.ca/contemporains/rigal_cellard_bernadette/ Peyote_way_church_of_god/Peyote_way_church.html

Rigal-Cellard, B. (2004). An analysis of the Peyote Way Church of God in the legal field. Paper presented at CESNUR 2004 
Conference, Waco, Texas. Retrieved from http://classiques. uqac.ca/contemporains/rigal_cellard_bernadette/Peyote_way_ church_of_god/Peyote_way_church.html

Roberts, B. H. (Ed.). (1902). History of the Church (Vol. 1, pp. 334-335). Salt Lake City, UT: Deseret News.

Roberts, B. H. (Ed.). (1908). History of the Church (Vol. 4, p. 580). Salt Lake City, UT: Deseret News.

Roberts, B. H. (Ed.). (1915). History of the Church (Vol. 6). Salt Lake City, UT: Deseret News.

Rolston-Cregler, L. (2017). Hallucinogenic mushroom toxicity. Medscape. Retrieved from https://emedicine.medscape.com/ article/817848-treatment\#d10

Rucker, J. J., Jelen, L. A., Flynn, S., Frowde, K. D., \& Young, A. H., (2016). Psychedelics in the treatment of unipolar mood disorders: A systematic review. Journal of Psychopharmacology, 30(12), 1220-1229. doi:10.1177/02698811166 79368

Rudgley, R. (1993). The alchemy of culture: Intoxicants in society. London, UK: British Museum Press.

Ruiz, J. F., Piper, A., \& Ruck, C. (2011). A prehistoric mural in Spain depicting neurotropic psilocybe mushrooms? Economic Botany, 65(2), 1-8. doi:10.1007/s12231-011-9152-5

Rush, J. A. (2011). The mushroom in Christian art: The identity of Jesus in the development of Christianity (p. 144). Berkeley, CA: North Atlantic Books.

Safford, W. E. (1922). Daturas of the Old World and New: An account of their narcotic properties and their use in oracular and initiatory ceremonies. Smithsonian report for 1920, 2622: 537-567. Washington, DC: Government Printing Office.

Satora, L., Pach, D., Butryn, B., Hydzik, P., \& Balicka- lusarczyk, B. (2005). Fly agaric (Amanita muscaria) poisoning, case report and review. Toxicon, 45(7), 941-943. doi:10.1016/j. toxicon.2005.01.005

Scarborough, J. (1971). Gnostîcism, drugs, and alchemy in Late Roman Egypt. Pharmacy in History, 13(4), 151-157. Retrieved from http://www.jstor.org/stable/41108719

Schaefer, S. B. (2015). Amada's blessings from the peyote gardens of south Texas. Albuquerque, NM: University of New Mexico Press.

Schiff, L. (2006). Ergot and its alkaloids. American Journal of Pharmaceutical Education, 70(5), 98. doi:10.5688/aj700598

Schultes, R. E. (1975). Hallucinogenic plants. New York, NY: Golden Press.

Shannon, B. (2008). Biblical entheogens: A speculative hypothesis. Time and Mind: The Journal of Consciousness and Culture, 1(1), 51-74. doi:10.2752/175169608783489116

Shelley, W. S. (1995). The Elixir: An alchemical study of the ergot mushrooms. Notre Dame, IN: Cross Cultural Pubs/Crossroads.

Shelley, W. S. (2017). Science, alchemy and the Great Plague of London. New York, NY: Algora Publishing.

Shields, S. (1982). Divergent paths of the restoration: A history of the Latter Day Saint movement (3rd ed.). Salt Lake City, UT: Restoration Research.

Shipps, J. (1987). Mormonism, the story of a new religious tradition. Chicago, IL: University of Illinois Press.

Sigmond, D. (1849). Correspondence from Paris. The Journal of Psychological Medicine and Mental Pathology, 2, 342.

Slotkin, J. S. (1955). Peyotism, 1527-1891. American Anthropologist, 57(2), 202-230. doi:10.1525/aa.1955.57.2.02a00030

Smith, F. M. (1918). The higher powers of man. Lamoni, IA: The Herald Publishing House.
Smith, G. A. (1867). Historical discourse (Vol. 11, pp. 1-12). Journal of Discourses. Liverpool, UK: Brigham Young.

Smith, H. (2000). Cleansing the doors of perception: The religious significance of entheogenic plans and chemicals (p. 11). Boulder, CO: Sentient Publications.

Smith, H. (2001). Do drugs have religious import? A thirty-five year retrospect. In T. B. Roberts (Ed.), Psychoactive sacramentals: Essays on entheogens and religion (pp. 11-18). San Francisco, CA: Council on Spiritual Practices.

Smith, H. C., \& Edwards, F. H. (Eds.). (1972). History of the reorganized Church of Jesus Christ of Latter Day Saints (Vol. 5, 646 n7). Independence, MO: Herald House.

Smith, J. (1830). The Book of Mormon: An account written by the hand of Mormon, upon plates taken from the plates of Nephi. Palmyra, Syria: E.B. Grandin.

Smith, J. (1832). Joseph Smith history, circa summer 1832. The Joseph Smith papers. Retrieved from https://www. josephsmithpapers.org/paper-summary/history-circa-summer$1832 / 2$

Smith, J. (1833). A Book of commandments for the government of the Church of Christ. Independence, MO: W. W. Phelps \& Co.

Smith, J. (1835). The doctrine and covenants of the Church of the Latter Day Saints: Carefully selected from the revelations of God. Kirtland, OH: F. G. Williams \& Co.

Smith, J. (1838). History, 1838-1856, volume A-1. Retrieved from https://www.josephsmithpapers.org/paper-summary/history1838-1856-volume-a-1-23-december-1805-30-august-1834

Smith, J. (1839). Discourse, between circa 26 June and circa 2 July 1839, as Reported by Willard Richards. Retrieved from https://www.josephsmithpapers.org/transcript/discoursebetween-circa-26-june-and-circa-2-july-1839-as-reported-bywillard-richards?print $=$ true $\# \mathrm{ft}$-source-note

Smith, J. (1839-1841). History, circa June 1839-circa 1841 [Draft 2]. Retrieved from https://www.josephsmithpapers.org/papersummary/history-circa-june-1839-circa-1841-draft-2

Smith, J. (1842). Times and seasons, 1 April 1842 (p. 748). The Joseph Smith Papers. Retrieved from https://www.joseph smithpapers.org/paper-summary/times-and-seasons-1-april$1842 / 14$

Smith, J. (1843). Revelation. The Latter Day Saints' Morning and Evening Star, 4(1), 116-118.

Smith, J. (1844). Conference minutes. In J. Taylor (Ed.), Times and seasons, containing a compendium of intelligence pertaining to the upbuilding of the Kingdom of God (Vol. 5, p. 615). Nauvoo, IL.

Smith, J. (1853). History of Joseph Smith. The Latter-Day Saints' Millennial Star, 15, 621.

Smith, J. (1977). Teachings of the Prophet Joseph Smith (Originally published 1938), J. F. Smith (Ed.), Salt Lake City, UT: Deseret Book Company.

Smith, L. M. (1853). Biographical sketches of Joseph Smith, the Prophet, and His progenitors for many generations. Liverpool, UK: S. W. Richards.

Smith, R. A. (1961). The Comanche Bridge between Oklahoma and Mexico, 1843-1844. Chronicles of Oklahoma, 39, 54-69.

Smith, S. (1692). Deposition of Samuel Smith v. Mary Esty. Essex County Court Archives, Salem-Witchcraft, 1, 292. Retrieved from http://salem.lib.virginia.edu/n45.html\#n45.20

Soni, P., Siddiqui, A., Dwivedi, J., \& Soni, V. (2012). Pharmacological properties of Datura stramonium L. as a potential medicinal 
tree: An overview. Asian Pacific Journal of Tropical Biomedicine, 2(12), 1002-1008. doi:10.1016/S2221-1691(13) 60014-3

Spence, L. (1920). An encyclopedia of occultism (p. 10). New York, NY: Dodd, Mead \& Company.

Spencer, J. M. (2009). The rise of Mormon cultural history and the changing status of the archive. ProQuest Dissertations and Theses, 182. Retrieved from https://search.proquest.com/ docview/305183687?accountid $=11664$

Stack, P. F. (2002). The Historic Nauvoo Temple. The Salt Lake Tribune, 4 May, C3. Retrieved from http://users.marshall.edu/ brown/nauvoo/SLT-05042002.html

Staker, M. L. (2009). Hearken, O ye people: The historical setting for Joseph Smith's Ohio revelations. Sandy, UT: Greg Kofford Books.

State of Utah. (2004, June 22). State of Utah, Plaintiff and Appellee, v. James W. Mooney, aka James W.B.E. Mooney, Linda T. Mooney, and Oklevueha Earthwalks Native American Church of Utah, Inc. Defendants and Appellants, No. 20010787. Retrieved from https://law.justia.com/cases/ utah/supreme-court/2004/mooney062204.html

Stewart, O. C. (1948). Ute Peyotism: A study of a cultural complex. Boulder, CO: University of Colorado Press.

Stewart, O. C. (1974). Origin of peyote religion in the United States. Plains Anthropologist, 19(65), 211-223. doi:10.1080/ 2052546.1974.11908677

Stewart, O. C. (1987). Peyote religion: A history. Norman, OK: University of Oklahoma Press.

Ström, Å. V. (1969). Red Indian Elements in Early Mormonism. Temenos - Nordic Journal of Comparative Religion, 5. Retrieved from https://journal.fi/temenos/article/view/6398

Sweta, V. R., \& Lakshmi, T. (2015). Pharmacological profile of tropane alkaloids. Journal of Chemical and Pharmaceutical Research, 7(5), 117-119. Retrieved from http:// www.jocpr.com/articles/pharmacological-profile-of-tropanealkaloids.pdf

Tanner, H. H. (1996). Travel and transportation routes. In F. E. Hoxie (Ed.), Encyclopedia of North American Indians (pp. 640-643). Boston, MA: Houghton Mifflin. Retrieved from https://login.ezproxy.lib.utah.edu/login? url=https:// search.credoreference.com/content/entry/hmenai/travel_and_ transportation_routes $/ 0$ ? institutionId $=6487$

Tanner, S. (n.d.). Masonic symbols and the LDS temple. Retrieved from http://www.utlm.org/onlineresources/ masonicsymbolsandtheldstemple.htm

Tantaquidgeon, G. (1972). Folk medicine of the Delaware and related Algonkian Indians, anthropological paper \#3 (p. 3). Harrisburg, PA: Pennsylvania Historical Commission.

Taves, A. (1999). Fits, trances, and visions: Experiencing religion and explaining experience from Wesley to James. Princeton, NJ: Princeton University Press.

Taves, A. (2014). History and the claims of revelation: Joseph Smith and the materialization of the golden plates. Numen, Special Issue: Methodological Debates in the Study of Religion, 61(2-3), 182-207. doi:10.1163/15685276-12341315

Taylor, L. (2010). Joseph Smith in Iroquois Country: The Handsome Lake Story. Juvenile Instructor (Unpublished PhD dissertation). Retrieved from https://juvenileinstructor.org/ joseph-smith-in-iroquois-country-the-handsome-lake-story/

Terry, M. (2017). Lophophora williamsii (amended version of 2013 assessment). The IUCN Red List of Threatened Species.
Retrieved from http://dx.doi.org/10.2305/IUCN.UK.2017-3. RLTS.T151962A121515326.en

Terry, M., Steelman, K. L., Guilderson, T., Dering, P., \& Rowe, M. W. (2006). Lower Pecos and Coahuila peyote: New radiocarbon dates. Journal of Archaeological Science, 33(7), 1017-1021. doi:10.1016/j.jas.2005.11.008

The Joseph Smith Papers. (1842-1844). Journal, December 1842 June 1844; Book 1, 21 December 1842-10 March 1843 (p. 242). Retrieved from https://www.josephsmithpapers. org/paper-summary/journal-december-1842-june-1844-book1-21-december-1842-10-march-1843/250-full-transcript

Thomson, A. T. (1832). Elements of materia medica and therapeutics (Vol. 1, p. 578). London, UK: Longman, Rees, Orme, Brown, Green, and Longman.

Thomson, S. (1841). The Thomsonian Materia Medica, or Botanic Family Physician. Albany, NY: J. Munsell.

Thornton, Dr. (1811). Communications relative to the Datura Stramonium, or Thorn-Apple: As a cure or relief of asthma. London: Richard Phillips.

Todd, J. M. (1968). New light on Joseph Smith's Egyptian papyri: Additional fragment disclosed. The Improvement Era, 71(2). Retrieved from https://ia800304.us.archive. org/3/items/improvementera7102unse/improvementera7102unse. pdf

Todd, J. M. (1969). The Saga of the Book of Abraham (pp. 278-281). Provo, UT: Deseret News Presses.

Tommasini, A. (1997). Virgil Thomson: Composer on the Isle. New York, NY: W. W. Norton \& Company.

Tooker, E., \& Sturtevant, W. C. (Eds.). (1979). Native North American Spirituality of the Eastern Woodlands (pp. 94-95). Mahwah, NJ: Paulist Press.

Troike, R. C. (1962). The origins of Plains Mescalism. American Anthropologist, 64(5), 946-963.

Underwood, L. G. (2006). Ordinary spiritual experience: Qualitative research, interpretive guidelines, and population distribution for the daily spiritual experience scale. Archive for the Psychology of Religion, 28(1), 181-218. doi:10.1163/ 008467206777832562

Underwood, L. G. (2011). Daily Spiritual Experience Scale. Religions, 2(1), 29-50. doi:10.3390/rel2010029

Van Dusen, I. M. (1847). Positively true: A dialogue between Adam and Eve, the Lord and the Devil, called the endowment. Albany, NY: C. Killmer.

Van Wagoner, R. S.. (1985). Mormon Polyandry in Nauvoo. Dialogue: A Journal of Mormon Thought, 18, 67-83.

Van Wagoner, R. S. (1989). Mormon Polygamy: A history. Salt Lake City, UT: Signature Books.

Vogel, D. (2003). Early Mormon documents (Vol. 5). Salt Lake City, UT: Signature Books.

Vogel, D. (2004). Joseph Smith: The making of a prophet. Salt Lake City, UT: Signature Books.

W. (1833). Cases of poisoning by Datura stramonium. Boston Medical Surgery Journal, 9(1), 10-13. doi:10.1056/ NEJM183308140090104

Walker, R. W. (1993). Seeking the 'Remnant': Native Americans during the Joseph Smith Period. Journal of Mormon History, 19(1), 1-33. Retrieved from https://digitalcommons.usu.edu/ cgi/viewcontent.cgi? article $=1020 \&$ context; $=$ mormonhistory

Wasson, G. R., Ruck, C. A. P., \& Hofmann, A. (2008). The road to Eleusis: Unveiling the secret of the mysteries (1978 Anniversary edition). Berkeley, CA: North Atlantic Books. 
Wasson, R. G., Kramrish, S., Ott, J., \& Ruck, C.A. (1986). Persephone's quest: Entheogens and the origins of religion. New Haven, CT: Yale University Press.

Waterman, B. (1999). The prophet puzzle: Interpretive essays on Joseph Smith. Salt Lake City, UT: Signature Books.

Watson, E. J. (1983). Joseph Smith's first vision: A harmony. Retrieved from http://www.eldenwatson.net/harmony.htm

Webster, N. (1828). An American dictionary of the English language (Vol. 2). New York, NY: S. Converse.

Webster, P., Perrine, D. M., \& Ruck, C. A. (2000). Mixing the Kykeon. Eleusis: Journal of Psychoactive Plants and Compounds, 4, 55-86. Retrieved from https://www.researchgate. net/publication/317412224_Mixing_the_Kykeon

Welch, J. W., \& Carlson, E. B. (Eds.). (2005). Opening the heavens: Accounts of divine manifestations, 1820-1844. Provo, UT: Brigham Young University Press.

Widtsoe, J. (1915). A rational theology as taught by the Church of Jesus Christ of Latter-day Saints. Salt Lake City, UT: General Priesthood Committee.

Wiebe, T. H., Sigurdson, E. S., \& Katz, L. Y. (2008). Angel's Trumpet (Datura stramonium) poisoning and delirium. Paediatrics \& Child Health, 13(3), 193-196. doi:10.1093/pch/13.3.193

Williams, F. G. (1972). Frederick Granger Williams of the First Presidency of the Church. Brigham Young University Studies, 12(3), 243-261. Retrieved from https://byustudies.byu.edu/ content/frederick-granger-williams-first-presidency-church

Williams, F. G. (2012). The medical practice of Dr. Frederick G. Williams. BYU Studies Quarterly, 51(1), 153-159. Retrieved from https://scholarsarchive.byu.edu/byusq/vol51/iss1/9

Winkelman, M. J. (2001). Psychointegrators: Multidisciplinary perspectives on the therapeutic effects of hallucinogens. Complementary Health Practice Review, 6(3), 219-237. doi:10.1177/ 153321010100600304

Winkelman, M. J. (2010). Shamanism: A biopsychosocial paradigm of consciousness and healing. Santa Barbara, CA: ABC-CLIO.
Winkelman, M. J. (2013). Shamanism and psychedelics: A biogenetic structuralist paradigm of ecopsychology. European Journal of Ecopsychology, 4, 90-115. Retrieved from https://pdfs.semanticscholar.org/8f69/0213afbbcf3a0ef3d1c62ce 2cbd75aa102ad.pdf

Winkelman, M. J., \& Baker, J. (2015). Supernatural as natural: A biocultural approach to religion. London, UK: Routledge.

Winkelman, M. J., \& Sessa, B. (Eds.). (2019). Advances in psychedelic medicine. Santa Barbara, CA: ABC-CLIO.

Wirthlin, L. S. (1981). Joseph Smith's boyhood operation: An 1813 surgical success. BYU Studies, 21(2), 131-154. Retrieved from https://scholarsarchive.byu.edu/byusq/vol21/iss $2 / 2 /$

Witkin, J. M., Overshiner, C., Li, X., Catlow, J. T., Wishart, G. N., Schober, D. A., \& Felder, C. C. (2014). M1 and M2 muscarinic receptor subtypes regulate antidepressant-like effects of the rapidly acting antidepressant scopolamine. Journal of Pharmacology and Experimental Therapeutics, 351(2), 448-456. doi:10.1124/jpet.114.216804

White, J. E. M. (2011). Everyday life of the North American Indian (2nd ed.). Mineola, NY: Dover Publications.

Woodward, R. J. (2012). Joseph Smith and 'The Vision,' 1832. In R. N. Holzapfel \& K. P. Jackson (Eds.), Joseph Smith, the Prophet and Seer (pp. 101-126). Provo, UT: Religious Studies Center, Brigham Young University.

Woolf, A. (2000). Witchcraft or mycotoxin? The Salem witch trials. Journal of Toxicology - Clinical Toxicology, 38(4), 457-460. doi:10.1081/CLT-100100958

Young, B. (1858). Journal of discourses (Vol. 5). Liverpool, UK: Asa Calkin.

Youngreen, B. (2001). Reflections of Emma, Joseph Smith's wife. Orem, UT: Grandin Book Company.

Yronwode, C. (2002). Hoodoo herb and root magic: A materia magica of African-American conjure, traditional formulary, given the spiritual uses of natural herbs, roots, mineral, and zoological curios. Forestville, CA: Lucky Mojo Curio Company. 